\title{
Review \\ The Bioactivity of Thiazolidin-4-Ones: A Short Review of the Most Recent Studies
}

\author{
Dominika Mech (D, Antonina Kurowska (D) and Nazar Trotsko *(D)
}

check for updates

Citation: Mech, D.; Kurowska, A.;

Trotsko, N. The Bioactivity of

Thiazolidin-4-Ones: A Short Review of the Most Recent Studies. Int. J. Mol. Sci. 2021, 22, 11533. https://doi.org/ 10.3390/ijms222111533

Academic Editor:

M. Graça P. M. S. Neves

Received: 20 September 2021

Accepted: 22 October 2021

Published: 26 October 202

Publisher's Note: MDPI stays neutral with regard to jurisdictional claims in published maps and institutional affiliations.

Copyright: (c) 2021 by the authors. Licensee MDPI, Basel, Switzerland. This article is an open access article distributed under the terms and conditions of the Creative Commons Attribution (CC BY) license (https:// creativecommons.org/licenses/by/ $4.0 /)$.
Department of Organic Chemistry, Faculty of Pharmacy, Medical University of Lublin, 20-093 Lublin, Poland; dominika-mech@wp.pl (D.M.); akurowska123@gmail.com (A.K.)

* Correspondence: nazar.trotsko@umlub.pl; Tel.: +48-81-448-72-44

\begin{abstract}
Thiazolidin-4-ones is an important heterocyclic ring system of a pharmacophore and a privileged scaffold in medicinal chemistry. This review is focused on the latest scientific reports regarding biological activities of thiazolidin-4-ones published in 2020 and 2021. The review covers recent information about antioxidant, anticancer, anti-inflammatory, analgesic, anticonvulsant, antidiabetic, antiparasitic, antimicrobial, antitubercular and antiviral properties of thiazolidin-4-ones. Additionally, the influence of different substituents in molecules on their biological activity was discussed in this paper. Thus, this study may help to optimize the structure of thiazolidin-4-one derivatives as more efficient drug agents. Presented information may be used as a practical hint for rational design of new small molecules with biological activity, especially among thiazolidin-4-ones.
\end{abstract}

Keywords: thiazolidine-4-ones; antioxidant activity; anticancer activity; anti-inflammatory activity; antidiabetic activity; antiparasitic activity; antimicrobial activity; antitubercular activity; multitarget activity; structure-activity relationship

\section{Introduction}

Heterocyclic compounds play an important role in many kinds of therapy, where thiazolidin-4-one have been reported to be a potential scaffold to construct new molecules for medicinal chemistry. Thiazolidin-4-one ring is susceptible for modification in Positions 2, 3 and 5. Such modifications capacitate the search for new compounds with desired activity. Literature reported that thiazolidin-4-one is one of the important scaffolds that has therapeutic importance. In case of its modification with other substituents, it shows wide range of biological activities, such as: antidiabetic [1], antioxidant [2], antitubercular [3], antimicrobial [4-7], anticonvulsant [8] anticancer [9-11], antiprotozoal [12,13] and antiinflammatory activities $[14,15]$. Additionally, thiazolidine-2,4-diones are well-known group of antidiabetic drugs (Pioglitazone, Rosiglitazone etc.) that reveal affinity to PPAR $\gamma[16,17]$.

The appearance of new information about the activity of thiazolidin-4-ones requires regular systematization and analysis. Therefore, in this review, we present the range of biological applications for thiazolidin-4-one derivatives published in 2020 and 2021. In addition, we outline the effect of substituents on their biological activity.

\section{Biological Activities of Thiazolidin-4-Ones}

\subsection{Antioxidant Activity}

Free radicals are important factors causing many pathological processes in the human body including the development of diseases of civilization. They can damage cell membranes, proteins, enzymes and DNA, which increase the risk of many conditions such as Parkinson's disease, Alzheimer's disease, angiocardiopathies, asthma, diabetes, atherosclerosis, eye degenerative diseases, chronic inflammation, neurodegenerative diseases and some types of cancer [18]. Reactive forms of oxygen and nitrogen are responsible for the oxidative deterioration of the quality of food products. Hence, nowadays there is a huge interest in compounds with antioxidant activity. The following studies demonstrate the 
effects of thiazolidine derivatives in this direction as well, taking into account how various substituents may condition and modulate antioxidant activity.

In 2020, a group of researchers published a paper which showed how certain substituents to the thiazolidine heterocyclic ring may be responsible for its adaptation to the human peroxiredoxin 5 enzymes [19]. This enzyme plays an important role in the process of fighting free radicals and protecting against oxidative stress. The antioxidant activity of Compounds 1a-1i, 2, 3a-3r, $\mathbf{4 a}$ and $\mathbf{4 b}$ on lipid peroxidation were evaluated by TBARS assay (Figure 1). The studies showed that the substitution of cyclohexyl moiety at Position 4 by the 4 -hydroxyphenyl substituent (Compounds $3 \mathbf{i}$ and $3 \mathbf{r}$ ) significantly increased the antioxidant activity in the structures. The Compounds $3 \mathbf{i}$ and $3 \mathbf{r}$ showed the best inhibitory activity of lipid peroxidation with $\mathrm{EC}_{50} 0.565 \pm 0.051$ and $0.708 \pm 0.074 \mathrm{mM}$, respectively. It has been shown that the lack of substitution at the $\mathrm{R}_{1}$ position increases the activity to a maximum (Compound 3i). The precursor of thiazolidine-4-one derivatives (3a-3r) Compounds 1a-1i showed antioxidant activity with $\mathrm{EC}_{50}$ in the range of $1.128-2.489 \mathrm{mM}$. Compounds containing a cyclopentyl moiety, Compounds $2\left(\mathrm{EC}_{50}=4.156 \pm 0.178 \mathrm{mM}\right), 4 \mathbf{a}$ $\left(\mathrm{EC}_{50}=3.30 \pm 0.271 \mathrm{mM}\right)$ and $\mathbf{4 b}\left(\mathrm{EC}_{50}=9.388 \pm 0.911 \mathrm{mM}\right)$, showed the lowest inhibitory capacity against lipid peroxidation among all tested derivatives.
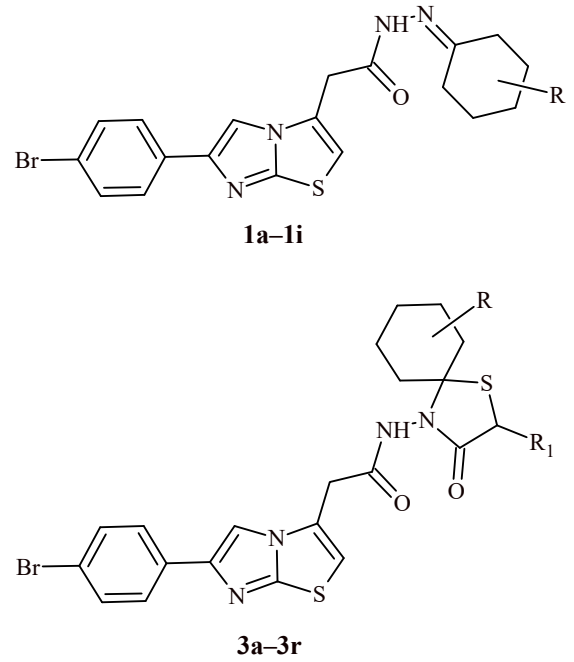
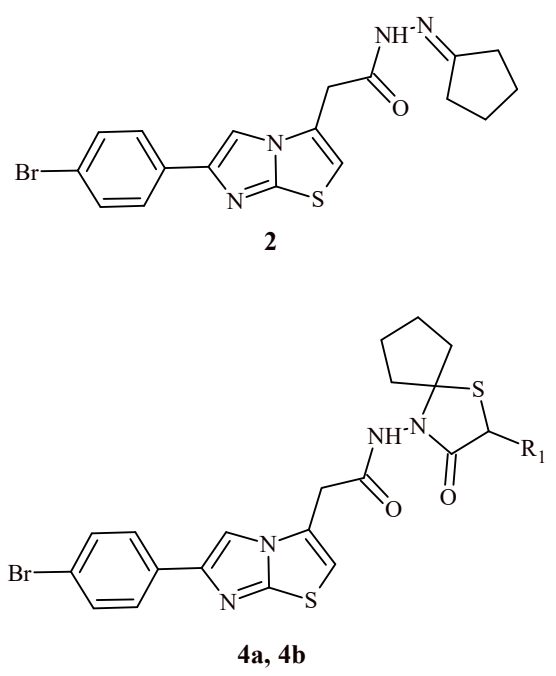

1a: $\mathrm{R}=\mathrm{H} ; 1 \mathbf{1 b}: \mathrm{R}=2-\mathrm{CH}_{3} ; \mathbf{1 c}: \mathrm{R}=3-\mathrm{CH}_{3} ; \mathbf{1 d}: \mathrm{R}=4-\mathrm{CH}_{3} ; \mathbf{1 e}: \mathrm{R}=4-\mathrm{C}_{2} \mathrm{H}_{5} ; \mathbf{1 f}: \mathrm{R}=4-\mathrm{C}_{3} \mathrm{H}_{7} ; 1 \mathrm{~g}: \mathrm{R}=4-\mathrm{C}\left(\mathrm{CH}_{3}\right)_{3} ; \mathbf{1 h}: \mathrm{R}=4-\mathrm{C}_{6} \mathrm{H}_{5} ; 1$ i: $\mathrm{R}=4-\mathrm{C}_{6} \mathrm{H}_{4}-4-\mathrm{OH}$ 3a: $\mathrm{R}=\mathrm{R}_{1}=\mathrm{H} ; 3 \mathbf{b}: \mathrm{R}=2-\mathrm{CH}_{3}, \mathrm{R}_{1}=\mathrm{H} ; \mathbf{3} \mathbf{c}: \mathrm{R}=3-\mathrm{CH}_{3}, \mathrm{R}_{1}=\mathrm{H} ; \mathbf{3 d}: \mathrm{R}=4-\mathrm{CH}_{3}, \mathrm{R}=\mathrm{H} ; \mathbf{3 e}: \mathrm{R}=4-\mathrm{C}_{2} \mathrm{H}_{5}, \mathrm{R}=\mathrm{H} ; \mathbf{3 f}: \mathrm{R}=4-\mathrm{C}_{3} \mathrm{H}_{7}, \mathrm{R}_{1}=\mathrm{H} ; \mathbf{3 g}: \mathrm{R}=4-\mathrm{C}\left(\mathrm{CH}_{3}\right)_{3}, \mathrm{R}_{1}=\mathrm{H}$ 3h: R=4- $\mathrm{C}_{6} \mathrm{H}_{5}, \mathrm{R}_{1}=\mathrm{H} ; 3 \mathbf{3}: \mathrm{R}=4-\mathrm{C}_{6} \mathrm{H}_{4}-4-\mathrm{OH}, \mathrm{R}_{1}=\mathrm{H} ; \mathbf{3 j}: \mathrm{R}=\mathrm{H}, \mathrm{R}_{1}=\mathrm{CH}_{3} ; \mathbf{3 k}: \mathrm{R}=2-\mathrm{CH}_{3}, \mathrm{R}_{1}=\mathrm{CH}_{3} ; 3 \mathbf{l}: \mathrm{R}=3-\mathrm{CH}_{3}, \mathrm{R}_{1}=\mathrm{CH}_{3} ; 3 \mathbf{m}: \mathrm{R}=4-\mathrm{CH}_{3}, \mathrm{R}_{1}=\mathrm{CH}_{3}$

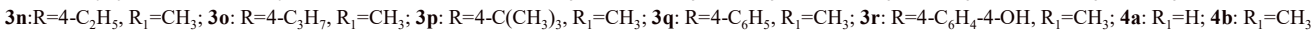

Figure 1. Imidazo[2,1-b]thiazole-thiazolidin-4-one hybrids (3a-3r, $4 \mathbf{a}$ and $\mathbf{4 b}$ ) and their precursors (1a-1i and 2) with antioxidant activity.

In addition, it was concluded from the modelling studies that the hydrogen bond interactions between the ligands and amino acids Cys47, Arg127, Thr44, Thr147, Gly46, Asp113 of the human peroxiredoxin 5 (PDB ID: 1HD2) showed significant antioxidant activity. Additionally, the overlapping of $\pi-\pi$ orbitals between the ligands and the receptorbuilding amino acid Phe120 may play a role in the process of action.

Another study contemplating on antioxidant activity of thiazolidine-2,4-dione (TZD) derivatives was published in 2020 by Kumar et al. [20]. The antioxidant activity of the 5-(-4-((substituted aryl/alkyl)methyl)benzylidene)thiazolidine-2,4-dione was assessed by applying DPPH radical scavenging method. Ascorbic acid was used as standard drug.

The antioxidant test showed that all twenty synthesized compounds (5a-5s and 6) were more active than the reference drug-ascorbic acid (Figure 2). Their $\mathrm{IC}_{50}$ was in the range of $9.18-32.43 \mu \mathrm{g} / \mathrm{mL}$. The most active derivative among all tested compounds was Derivative 6. The Compound $\mathbf{6}$ with (furan-2-ylmethyl)imino substituent showed prominent antioxidant activity results $\left(\mathrm{IC}_{50}=9.18 \mu \mathrm{g} / \mathrm{mL}\right)$ compared to the reference drug 
$\left(\mathrm{IC}_{50}=40 \mu \mathrm{g} / \mathrm{mL}\right)$. Additionally, Compounds 5c, 5d, 5i, 5r and $5 \mathbf{s}$ were 2 -fold more active than ascorbic acid with $\mathrm{IC}_{50}$ values in the range of $12.67-18.02 \mu \mathrm{g} / \mathrm{mL}$. Whereas Compound $5 \mathrm{~m}$ with two electron-withdrawing groups $\left(\mathrm{NO}_{2}\right.$ and $\left.\mathrm{Cl}\right)$ in the benzene ring exhibited the lowest antioxidant activity with $\mathrm{IC}_{50}=32.43 \mu \mathrm{g} / \mathrm{mL}$.<smiles>[R]N=Cc1ccc(/C=C2\SC(=O)NC2=O)cc1</smiles>

$5 \mathbf{a}-\mathbf{5 s}$<smiles>O=C1NC(=O)/C(=C/c2ccc(/C=N/Cc3ccco3)cc2)S1</smiles>

5a: $\mathrm{R}=\mathrm{C}_{6} \mathrm{H}_{5} ; \mathbf{5 b}: \mathrm{R}=\mathrm{NH}_{2} ; \mathbf{5 c}: \mathrm{R}=\mathrm{C}_{6} \mathrm{H}_{5} \mathrm{NH} ; \mathbf{5 d}: \mathrm{R}=2-\mathrm{Cl}_{-} \mathrm{C}_{6} \mathrm{H}_{4} ; \mathbf{5 e}: \mathrm{R}=3-\mathrm{Cl}_{-} \mathrm{C}_{6} \mathrm{H}_{4} ; \mathbf{5 f}: \mathrm{R}=3-\mathrm{CH}_{3}-\mathrm{C}_{6} \mathrm{H}_{4}$ 5g: $\mathrm{R}=4-\mathrm{CH}_{3}-\mathrm{C}_{6} \mathrm{H}_{4} ; \mathbf{5 h}: \mathrm{R}=2,4-\mathrm{diCH}_{3}-\mathrm{C}_{6} \mathrm{H}_{3} ; \mathbf{5 i}: \mathrm{R}=2,6-\mathrm{diCH}_{3}-\mathrm{C}_{6} \mathrm{H}_{3} ; \mathbf{5 j}: \mathrm{R}=2-\mathrm{F}-\mathrm{C}_{6} \mathrm{H}_{4} ; \mathbf{5 k}: \mathrm{R}=4-\mathrm{Br}^{-} \mathrm{C}_{6} \mathrm{H}_{4}$ 5I: $\mathrm{R}=3-\mathrm{NO}_{2}-\mathrm{C}_{6} \mathrm{H}_{4} ; \mathbf{5 m}: \mathrm{R}=2-\mathrm{NO}_{2}-4-\mathrm{Cl}_{-} \mathrm{C}_{6} \mathrm{H}_{3} ; \mathbf{5 n}: \mathrm{R}=2-\mathrm{CH}_{3} \mathrm{O}-\mathrm{C}_{6} \mathrm{H}_{4} ; \mathbf{5 o}: \mathrm{R}=3-\mathrm{CH}_{3} \mathrm{O}-\mathrm{C}_{6} \mathrm{H}_{4}$ 5p: $\mathrm{R}=4-\mathrm{CH}_{3} \mathrm{O}-\mathrm{C}_{6} \mathrm{H}_{4} ; \mathbf{5 q}: \mathrm{R}=4-\mathrm{F}-\mathrm{C}_{6} \mathrm{H}_{4} ; \mathbf{5 r}: \mathrm{R}=4-\mathrm{NO}_{2}-\mathrm{C}_{6} \mathrm{H}_{4} ; \mathbf{5 s}: \mathrm{R}=\mathrm{C}_{12} \mathrm{H}_{25}$

Figure 2. The 5-Arylidenethiazolidine-2,4-dione derivatives (5a-5s) and 6 with antioxidant and antimicrobial activity.

Sava et al. conducted synthesis of thiazolidin-4-one-indometacin hybrids and evaluated their antioxidant activity with use of DPPH radical scavenging method [21]. The most active derivatives from whole series were Compounds 7 and 8 with $\mathrm{IC}_{50}$ values $0.54 \pm 0.01$ and $1.82 \pm 0.05 \mathrm{mM}$, respectively (Figure 3). Moreover, vitamin C equivalent antioxidant capacity $(\mathrm{CEAC})$ value was determined. The CEAC value show how many times tested compounds are more active than vitamin $C$. All tested compounds were less active than vitamin $C$ used as positive control. The most potent derivative was Compound 7 with the CEAC value $0.137 \pm 0.01$ vs. 1 for vitamin C. Furthermore, Compound 7 revealed around 100 -fold more activity than indometacin (CEAC value $0.0014 \pm 0.0002$ ).<smiles>COc1ccc2c(c1)c(CC(=O)NN1C(=O)CSC1c1ccc(OCCO[N+](=O)[O-])cc1[N+](=O)[O-])c(C)n2C(=O)c1ccc(Cl)cc1</smiles><smiles>COc1ccc2c(c1)c(CC(=O)NN1C(=O)CSC1c1ccccc1OCCO[N+](=O)[O-])c(C)n2C(=O)c1ccc(Cl)cc1</smiles>

Figure 3. Thiazolidin-4-one-indometacin hybrids with antioxidant properties.

The series of oxazinyl-thiazolidin-4-ones (9a-9f) were tested for their antioxidant activity in DPPH and nitric oxide (NO) radical scavenging activity assays (Figure 4) [22]. The Compound 9a showed highest antioxidant activity with $\mathrm{IC}_{50}$ values of $6.62 \mu \mathrm{g} / \mathrm{mL}$ (DPPH assay) and $6.79 \mu \mathrm{g} / \mathrm{mL}$ (NO assay). Compound 9c was also worthy of attention because it exhibited antioxidant activity at concentration 9.33 and $6.05 \mu \mathrm{g} / \mathrm{mL}$, correspondingly 
for DPPH and NO tests. Other derivatives showed less antioxidant activity than standard ascorbic acid ( $\mathrm{IC}_{50}$ values of $22.88 \mu \mathrm{g} / \mathrm{mL}$ for DPPH assay and $12.61 \mu \mathrm{g} / \mathrm{mL}$ for NO test).<smiles>[R]c1ccc(C2=CC(c3cccs3)OC(N3C(=O)CSC3c3ccc([R])cc3)=N2)cc1</smiles>

9a-9f 9a: $\mathrm{R}=\mathrm{CH}_{3}, \mathrm{R}_{1}=\mathrm{NO}_{2}$

9b: $\mathrm{R}=\mathrm{CH}_{3}, \mathrm{R}_{1}=\mathrm{Cl}$

9c: $\mathrm{R}=\mathrm{OCH}_{3}, \mathrm{R}_{1}=\mathrm{CH}_{3}$

9d: $\mathrm{R}=\mathrm{OCH}_{3}, \mathrm{R}_{1}=\mathrm{NO}_{2}$

9e: $\mathrm{R}=\mathrm{Cl}, \mathrm{R}_{1}=\mathrm{CH}_{3}$

9f: $\mathrm{R}=\mathrm{Cl}, \mathrm{R}_{1}=\mathrm{OCH}_{3}$

Figure 4. The oxazinyl-thiazolidin-4-ones (9a-9f) with antioxidant activity.

Shetty et al. synthesized thiazolidin-4-one-benzothiazole hybrids (10a-10f) and conducted their evaluation for antioxidant activity (Figure 5) [23]. For evaluation of antioxidant activity three different models (DPPH, nitric oxide and superoxide anion radical scavenging assays) were used. The most effective compound was Derivative $10 \mathrm{~d}$ with $\mathrm{IC}_{50}$ values of $30.9 \mu \mathrm{g} / \mathrm{mL}$ (DPPH), $33.82 \mu \mathrm{g} / \mathrm{mL}$ (NO) and $31.88 \mu \mathrm{g} / \mathrm{mL}$ (Superoxide anion). However, these concentrations were higher than those for ascorbic acid used as standard ( $\mathrm{IC}_{50}$ values in the range of $24.99-25.73 \mu \mathrm{g} / \mathrm{mL}$ ).<smiles>[R]c1ccc(C2SCC(=O)N2c2nc3ccc(C)cc3s2)cc1</smiles>

Figure 5. The thiazolidin-4-one-benzothiazole hybrids with antioxidant activity.

Carraro Junior et al. conducted evaluation of 3-(pyridin-2-yl)-2-(pyridine-2-ylimino)thiaz olidin-4-one (PPIT) for their antioxidant activity and inhibition potential of monoamine oxidase (MAO) [24]. The studies demonstrated that PPIT (Figure 6) has antioxidant and reducing activity according to the ABTS, DPPH, FRAP and PC assays. Additionally, PPIT selectively inhibited the activity of cerebral MAO-B isoform in concentration equal to or greater than $200 \mu \mathrm{M}$. The compound PPIT inhibited MAO-A isoform in none of the tested concentrations.<smiles>O=C1CS/C(=N\c2ccccn2)N1c1ccccn1</smiles>

Figure 6. The structure of 3-(pyridin-2-yl)-2-(pyridine-2-ylimino)thiazolidin-4-one (PPIT). 
Verma et al. reported that Compound 11 (Figure 7) demonstrated excellent radical scavenging activity $(78.83 \%$ of inhibition at concentration $100 \mu \mathrm{g} / \mathrm{mL})$. The evaluation was carried out by the DPPH test [25]. Compound $\mathbf{1 2}$ with indolyl-pyridine moiety in structure showed more potent radical scavenging activity than $\mathbf{1 1}(80.89 \%, 86.02 \%, 89.86 \%$ and $92.05 \%$ at concentration $25,50,75$ and $100 \mu \mathrm{g} / \mathrm{mL}$, respectively) [26].<smiles>O=C1CSC(c2c(-c3ccccc3)[nH]c3ccc(Cl)cc23)N1c1nnc(Sc2nc3c4cc(Cl)ccc4[nH]c3c3ccccc23)o1</smiles><smiles>N#CC1=C(c2c(-c3ccccc3)[nH]c3ccccc23)C=C(c2ccccc2)NC1N1C(=O)CSC1c1c(-c2ccccc2)[nH]c2ccc(Cl)cc12</smiles>

Figure 7. The structures of Compounds 11 and 12.

\subsection{Anticancer Activity}

Malignant neoplasms are diseases that occur commonly in our population and have a relatively high mortality rate. It is the second leading cause of death in developed countries, after cardiovascular disease. For many years, both the morbidity and mortality rate from malignant neoplastic diseases have been increasing. Only in recent years this tendency is slowed down [27]. The background to this state of affairs is the change in the demographic structure of societies over the years as well as the exposure to carcinogens, not all recognized to this day. In Poland, there are 155,000 cases and 93,000 deaths annually [28].

Vascular endothelial growth factor (VEGF) is a well-characterized pro-angiogenic factor, necessary for the formation of new blood vessels during both embryonic development and pathological conditions. Research conducted recently has indicated a new role of VEGF as a neurotrophic factor [29].

The 5-(4-Methoxybenzylidene)thiazolidin-2,4-dione derivatives (13a-13e, 14, 15 and 16a-16f) were tested for their activity against the HepG2, HCT116 and MCF-7 cell lines [30,31]. Among all tested derivatives (Figure 8), Compounds 16f, 16e, 16d and 16c showed the highest antiproliferative activity in the in vitro studies against HepG2, HCT116 and MCF-7 cell lines. Their $\mathrm{IC}_{50}$ values were in the range of 5.1-22.08 $\mu \mathrm{M}$. Compound 16f showed most potent activity. It inhibited proliferation of HepG2 $\left(\mathrm{IC}_{50}=6.19 \pm 0.50 \mu \mathrm{M}\right)$ and MCF-7 $\left(\mathrm{IC}_{50}=5.10 \pm 0.40 \mu \mathrm{M}\right)$ cells better than reference drugs sorafenib $\left(\mathrm{IC}_{50}=9.18 \pm 0.60 \mu \mathrm{M}\right.$ for HepG2 and $\mathrm{IC}_{50}=7.26 \pm 0.30 \mu \mathrm{M}$ for MCF-7) and doxorubicin ( $\mathrm{IC}_{50}=7.94 \pm 0.60 \mu \mathrm{M}$ and $\mathrm{IC}_{50}=6.75 \pm 0.40 \mu \mathrm{M}$ for HepG2 and MCF-7, respectively). Derivative 16f exhibited also activity against HCT116 comparable to doxorubicin $(8.37 \pm 0.70 \mu \mathrm{M}$ vs. $8.07 \pm 0.80 \mu \mathrm{M})$. All the obtained derivatives were tested for inhibitory activity against the vascular endothelial growth factor receptor-2 (VEGFR-2). Among them Compound 16f exhibited most potent inhibitory activity with $\mathrm{IC}_{50}$ value $0.12 \pm 0.02 \mu \mathrm{M}$ that was comparable with results for reference drug sorafenib $\left(\mathrm{IC}_{50}=0.10 \pm 0.02 \mu \mathrm{M}\right)$. Moreover, Compounds 16e, 16d, 16c and $16 \mathbf{b}$ showed also high potential towards VEGFR-2 with $\mathrm{IC}_{50}$ values $0.13 \pm 0.02,0.14 \pm 0.02$, $0.14 \pm 0.02$ and $0.18 \pm 0.03 \mu \mathrm{M}$, correspondingly. 
<smiles>[R]c1ccc(NC(=O)CN2C(=O)S/C(=C\c3ccc(OC)cc3)C2=O)cc1</smiles><smiles>COc1ccc(/C=C2\SC(=O)N(CC(=O)Nc3nccs3)C2=O)cc1</smiles><smiles>COc1ccc(/C=C2\SC(=O)N(CC(=O)Nc3ccccn3)C2=O)cc1</smiles><smiles>[R]NC(=O)c1ccc(NC(=O)CN2C(=O)S/C(=C\c3ccc(OC)cc3)C2=O)cc1</smiles>

13a: $\mathrm{R}=\mathrm{H} ; 13 \mathrm{~b}: \mathrm{R}=\mathrm{CH}_{3} ; 1$ 13c: $\mathrm{R}=\mathrm{COOH} ; 13 \mathrm{~d}: \mathrm{R}=\mathrm{COOC}_{2} \mathrm{H}_{5} ; 13 \mathrm{e}: \mathrm{R}=\mathrm{NO}_{2}$

16a: $\mathrm{R}=\mathrm{C}_{2} \mathrm{H}_{5} ; 16 \mathbf{b}: \mathrm{R}=\mathrm{C}_{3} \mathrm{H}_{7} ; 16 \mathbf{c}: \mathrm{R}=\mathrm{C}_{4} \mathrm{H}_{9} ; 16 \mathbf{d}: \mathrm{R}=\mathrm{C}_{6} \mathrm{H}_{5} \mathrm{CH}_{2} ; 16 \mathrm{e}: \mathrm{R}=4-\mathrm{CH}_{3}-\mathrm{C}_{6} \mathrm{H}_{4} ; 16 f: \mathrm{R}=4-\mathrm{C}_{2} \mathrm{H}_{5} \mathrm{OOC}-\mathrm{C}_{6} \mathrm{H}_{4}$

Figure 8. The 5-(4-Methoxybenzylidene)thiazolidin-2,4-dione Derivatives 13a-13e, 14, 15 and 16a-16f with inhibitory effect on VEGFR-2.

The next step of assay was molecular docking studies that was performed to investigate binding mode and affinities of compounds towards VEGFR-2. The docking studies performed in the Molsoft software showed that all derivatives assume a similar position and orientation at the receptor binding site. The proposed model of connection takes into account the affinity of the Derivative $16 \mathrm{f}$ with a value of $-103.50 \mathrm{kcal} / \mathrm{mol}$ and the formation of six hydrogen bonds. The carbonyl group at the position of the second thiazolidine-2,4-dione derivative joins forms one of these bonds with Asp1044. In addition, the NH group of the carboxamide linker forms another bond with Glu915. The oxygen atom from the carboxyl group stabilized the hydrogen bonds formed with Arg1025 and Ile1023. The 4-methoxybenzylidene substituent located in the hydrophobic cavity was formed by Arg1025, His1024, Ile1023, Cys1022, Leu1017, Ile890 and Ile886. Furthermore, the thiazolidin-2,4-one moiety itself occupies the hydrophobic cavity formed by Asp1044, Ile890, Leu887, Ile886 and Glu883. The central phenyl group is attached to the cavity provided by Leu1033, Cys917, Phe916, Leu838, and Ala864. The distant ethyl group, on the other hand, combines with the hydrophobic cleft formed by Gly920, Phe919, Lys918, Phe916 and Leu838. The described interactions help to understand the nature of such a strong anti-cancer effect of the $\mathbf{1 6 f}$ derivative.

Molecular docking studies carried out for the remaining derivatives showed that the acetamide linker occupies the same cavity as the urea linker contained in the sorafenib structure. This plays a key role in increasing the affinity for the VEGFR-2 enzyme. The 4-methoxybenzylidene derivative compensates for the $N$-methylpicolinamide substituent effect of sorafenib and increase the chance for hydrogen bond formation as well as increase similarity towards the VEGFR-2 enzyme. The tiazolidine-2,4-dione core enables new compounds to form new hydrogen bonds via the carbonyl group at Position 2 with the basic amino acid Asp1044. Structure elongation plays an important role in the inhibition of VEGFR-2. Hydrophobic distal substituents and their connections give the chance for hydrogen bonds to be formed with the amino acid Glu915, which further increases the similarity to the VEGFR-2 enzyme. Worth noticing that the results of molecular docking studies are correlated very well with biological screening results. The obtained results show the potential usefulness of the considered compounds for the future design, optimization, adaptation and research in order to produce more potent and selective inhibitors of VEGFR2 with higher anti-cancer analogues.

Tyrosinase is a catalyst that regulates the duration of the melanin synthesis process. Melanin is synthesized from L-tyrosine in melanosomes, where this process is controlled by many factors, including tyrosinase [32]. 
Studies carried out by Isogawa et al. showed that the rhodanine Derivative 17c (with 4-fluorobenzylidene substituent) strongly inhibited the melanogenesis process in mouse melanoma B16F10 cells in $10 \mu \mathrm{M}$ concentration (Figure 9) [33]. Compound 17c reduced the level of tyrosinase activity without modifying its messenger RNA levels or enzymatic activity. This derivative may promote the degradation of tyrosinase proteins; however, this degradation may be associated with simultaneous protein synthesis. Taking this into account, it was found that the Compound 17a also lowered the activity level of the tyrosinase proteins, while having no effect on tyrosinase related protein 1 (TYRP-1), another protein involved in the melanogenesis process. Compound 17a (with benzylidene substituent) promotes the breakdown of tyrosinase from TYRP-1 in B16F10 cells. In injured cells, tyrosinase is localized together with TYRP-1 in two regions-the peripheral and the nuclear. The Compound 17a amplified the peri-nuclear signals while reducing the frequency of the peripheral signals. Other rhodanine Derivatives 17b (with 4-chlorobenzylidene substituent), 17d (with 4-methoxybenzylidene substituent) and 17e (with 4-hydroxybenzylidene substituent) were less effective than Compound 17c.

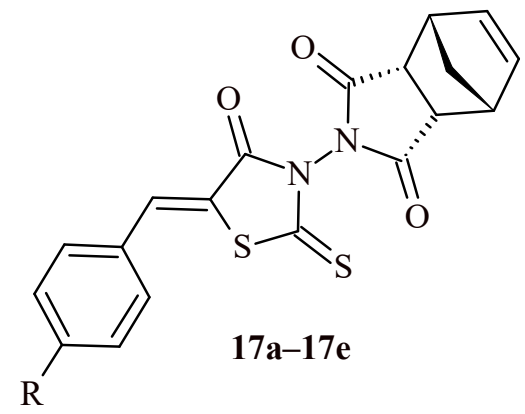

17a: $\mathrm{R}=\mathrm{H}, \mathbf{1 7 b}: \mathrm{R}=\mathrm{Cl}, \mathbf{1 7} \mathbf{c}: \mathrm{R}=\mathrm{F}, \mathbf{1 7 d}: \mathrm{R}=\mathrm{OCH}_{3}, \mathbf{1 7 e}: \mathrm{R}=\mathrm{OH}$

Figure 9. Rhodanine derivatives that inhibited melanogenesis.

Considering the chemical structure, it can be seen that the phenyl group is the factor which determines the activity of the compounds. The phenyl group should not be modified (Compound 17a) to preserve the stability of the compounds. Substitution with a fluorine (17c) (but not chloro- 17b) atom in the para position of phenyl group is acceptable since this does not affect the activity of the compound. Compounds (17a-17e) were also analyzed for their hydrophobicity. No correlation was found between hydrophobicity and their potency.

Breast cancer is the most common cancer in women and ranks second in the number of deaths in women [34]. The demand for drugs to combat this cancer is incredibly high Due to the wide spectrum of activity of thiazolidin-2,4-one derivatives, there are several reports about the breast cancer activity of these compounds.

In a 2020, El-Kashef et al. synthesized series of TZD derivatives with 5-(3,4,5-trimethoxy benzylidene) moiety (Figure 10). The synthesized TZDs were tested for their anti-breast cancer activity against human breast cancer cells (MCF-7 and MDA-MB-231) and also against normal non-cancerous breast cells that were obtained from the same patients [35]. Initial screening studies showed that Compounds 18, 19 and 20 had the greatest anticancer activity. These derivatives inhibited the proliferation of breast cancer cells in a dose-dependent manner with an $\mathrm{IC}_{50}$ of $1.27,1.50$ and $1.31 \mu \mathrm{M}$ respectively. Using flow cytometric analysis, it was found that these three compounds mediated apoptosis of human breast cancer cells without affecting the survival of normal non-cancerous breast cells that had been isolated from the same patients. These compounds $(\mathbf{1 8}, \mathbf{1 9}$ and $\mathbf{2 0})$ strongly inhibited the proliferation of MCF-7 breast cancer cells by reducing the phosphorylation of AKT, mTOR and expression of VEGF and HIF- $1 \alpha$. 

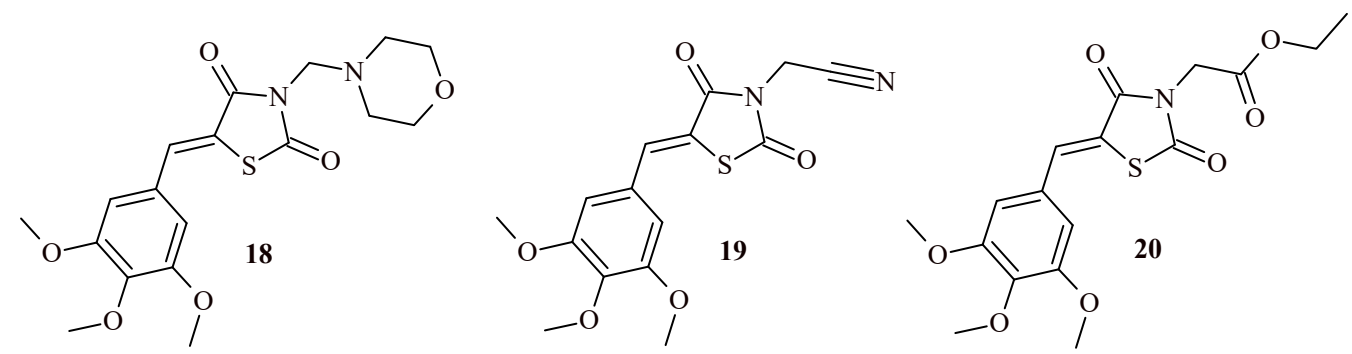

Figure 10. The 5-(3,4,5-trimethoxybenzylidene)thiazolidine-2,4-dione derivatives with anti-breast cancer activity.

Aziz et al. conducted the synthesis of series quinazolinone-thiazolidin-4-one hybrids (21a-21e) and evaluated their anticancer activity against breast cancer (MCF-7) and lung cancer (A549) cell lines (Figure 11). Additionally, EGFR inhibitory activity of synthesized compounds was carried out [36].<smiles>[R]c1ccc(/C=C2\SC(Nn3c(-c4ccccc4)nc4ccccc4c3=O)=NC2=O)cc1</smiles>

21a: $\mathrm{R}=\mathrm{H}, \mathbf{2 1 b}: \mathrm{R}=4-\mathrm{OCH}_{3}, 21 \mathrm{c}: \mathrm{R}=4-\mathrm{Br}$

21d: $\mathrm{R}=2,4-\mathrm{diOH}, 21 \mathrm{e}: 3,4-\mathrm{diOCH}_{3}$

Figure 11. The structures of thiazolidin-4-one derivatives with EGFR inhibitory activity.

Compounds 21a-21d showed significant cytotoxic effect against both MCF-7 and A549 cell lines (Table 1).

Table 1. Anticancer activity of the synthesized compounds (21a-21e) against MCF-7 and A549 cell lines.

\begin{tabular}{ccc}
\hline \multirow{2}{*}{ Compound } & \multicolumn{2}{c}{ IC $_{\mathbf{5 0}, \boldsymbol{\mu M}}$} \\
\cline { 2 - 3 } & MCF-7 & A549 \\
\hline 21a & $4.05 \pm 0.09$ & $0.72 \pm 0.03$ \\
21b & $3.76 \pm 0.08$ & $5.31 \pm 0.2$ \\
21c & $2.30 \pm 0.05$ & $21.3 \pm 0.9$ \\
21d & $7.49 \pm 0.16$ & $3.22 \pm 0.1$ \\
21e & $1.003 \pm 0.02$ & $44.7 \pm 1.8$ \\
erlotinib & $11.18 \pm 0.24$ & $10.0 \pm 0.4$ \\
gefitinib & $3.57 \pm 0.09$ & $3.53 \pm 0.1$ \\
\hline
\end{tabular}

However, Compound 21e with electron donating groups (3,4-dimethoxy substituted derivative) was most active against MCF-7 cell line with $\mathrm{IC}_{50}$ value of $1.003 \mu \mathrm{M}$. It is worth noticing that unsubstituted Compound 21a showed highest cytotoxic activity against A549 cell line with $\mathrm{IC}_{50}=0.72 \mu \mathrm{M}$ and more EGFR inhibitory activity at concentration $65.63 \mathrm{nM}$. Moreover, Compound 21a exhibited good normal cell cytotoxicity profile $\left(\mathrm{IC}_{50}=44.34 \mu \mathrm{M}\right)$.

Abumelha and Saeed synthesized series of 5-arylidene-2-(4-acetamidophenylimino)thi azolidine-4-one derivatives and carried out their evaluation for anti-breast cancer activity (MCF-7) with use of MTT assay. Among series of ten compounds most active was Com- 
pound 22 (Figure 12). It showed half maximal inhibitory concentration at $58.33 \mu \mathrm{M}$. As a standard doxorubicin $\left(\mathrm{IC}_{50}=48.06 \mu \mathrm{M}\right)$ was used [37].<smiles>CC(=O)Nc1ccc(/N=C2\S/C(=C\c3ccc(Cl)cc3)C(=O)N2c2ccc(NC(C)=O)cc2)cc1</smiles><smiles>CCCN1C(=O)/C(=C/c2cc3cc(OC)ccc3[nH]c2=O)S/C1=N\c1ccccc1</smiles><smiles>[R]c1ccc2[nH]c(=O)c(/C=C3\S/C(=N\c4ccccc4)N(Cc4ccc(F)cc4)C3=O)cc2c1</smiles>

Figure 12. The structures of 2-iminothiazolidin-4-one derivatives with anti-breast cancer activity.

Kumar et al. conducted evaluation of anti-breast cancer activity of series of quinolinonethiazolidin-4-one hybrids with use of MTT test on MCF-7 and MDA-MB-231 cell lines. As a result of the study, it was found that Compounds 23, 24a-24d were most potent in the series. Compound $24 \mathrm{~b}$ showed the best activity against MDA-MB-231 cell line $\left(\mathrm{IC}_{50}=8.16 \mu \mathrm{M}\right)$, meanwhile Compound 24c was most effective against MCF-7 cancer cells $\left(\mathrm{IC}_{50}=18.03 \mu \mathrm{M}\right)$ (Table 2). It is worth noticing that Compounds $\mathbf{2 3}$ and $\mathbf{2 4 a - 2 4 d}$ had low cytotoxicity towards HEK-293 cells [38].

Table 2. The anticancer activity of quinolinone-thiazolidin-4-one hybrids 23 and $24 a-24 d$.

\begin{tabular}{cccc}
\hline \multirow{2}{*}{ Compound } & \multicolumn{3}{c}{ IC $_{\mathbf{5 0}}, \boldsymbol{\mu M}$} \\
\cline { 2 - 4 } & MDA-MB-231 & MCF-7 & HEK-293 \\
\hline $\mathbf{2 3}$ & 17.68 & 39.38 & $>1000$ \\
$\mathbf{2 4 a}$ & 18.75 & 24.72 & $>1000$ \\
$\mathbf{2 4 b}$ & 8.16 & 33.86 & 846.93 \\
$\mathbf{2 4 c}$ & 44.24 & 18.03 & 409.72 \\
24d & 22.20 & 36.98 & 682.12 \\
cisplatin & 1.66 & 4.99 & NT \\
\hline
\end{tabular}

NT-not tested.

The series of Compounds $\mathbf{2 5 a - 2 5 g}$ was synthesized by Nissan et al. (Figure 13). These derivatives were assessed against colon (HCT-116), lung (A549), breast (MCF-7) and liver (HepG2) cancer cell lines with use of sulforhodamine B method. For the colon and lung cancer cell lines none of the tested compounds exhibited equal or better activity that standard drug doxorubicin $\left(\mathrm{IC}_{50}\right.$ were 0.058 and $0.27 \mu \mathrm{M}$, respectively). The Compounds 25a-25g were active at half maximal inhibitory concentration in the range of $8.91-58.66 \mu \mathrm{M}$ (HCT-116) and 11.73-60.47 $\mu \mathrm{M}$ (A549). Compound 25e was most effective from series towards colon and lung cancer cell lines $\left(\mathrm{IC}_{50}=8.91\right.$ and $\left.11.73 \mu \mathrm{M}\right)$. The Compounds $25 \mathrm{~b}$ and $25 \mathrm{c}$ were between 4.5 to 2.7 -fold more active towards breast cancer cells (MCF-7) than doxorubicin $\left(\mathrm{IC}_{50}=1.50 \mu \mathrm{M}\right)$. In addition, Compounds $\mathbf{2 5 b}-\mathbf{2 5 d}$ showed high cytotoxicity against HepG2 cell line with $\mathrm{IC}_{50}$ values of $1.58,0.24$ and $2.28 \mu \mathrm{M}$, respectively. Compound 25c was 3.7-fold more effective than doxorubicin $\left(\mathrm{IC}_{50}=0.90 \mu \mathrm{M}\right.$ ), whereas Derivative 25e was weakly active $\left(\mathrm{IC}_{50}>100 \mu \mathrm{M}\right)$. Additionally, the most potent Compounds 25b, 25c and 25e exhibited low cytotoxicity against normal breast cell line MCF-10A, showing good selectivity; SI > 270, > 185 and > 5.8, respectively [39]. 


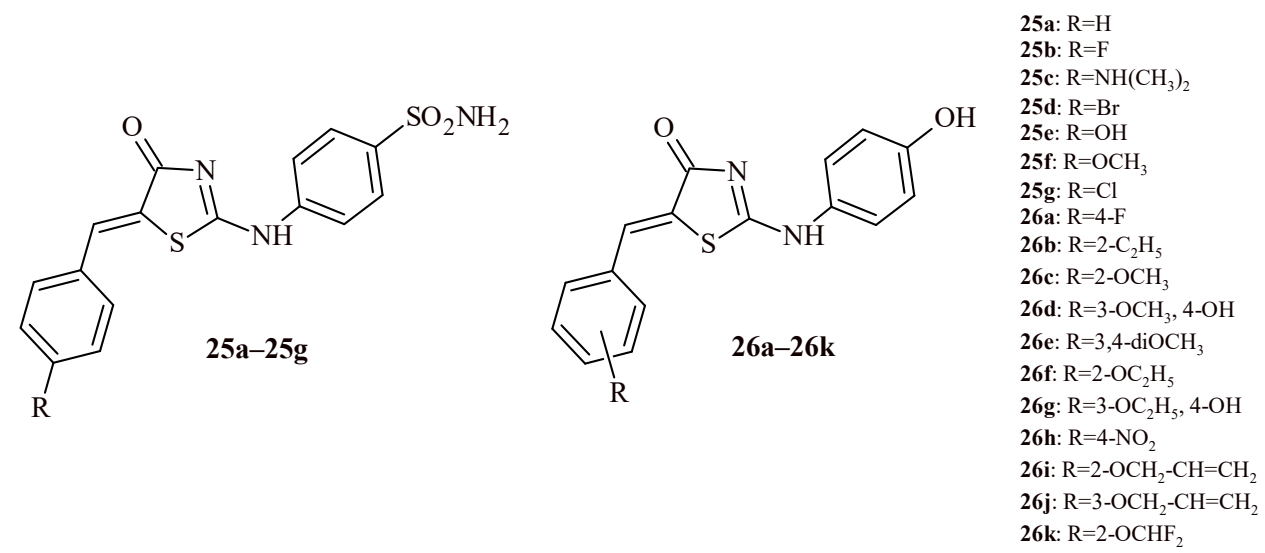

Figure 13. The structures of 5-arylidene-2-phenylaminothiazol-4(5H)-one derivatives with antiproliferative activity.

In the next study the evaluation of 5-arylidene-2-phenylaminothiazol-4(5H)-ones against ten leukemia cell lines (four Ba/F3 cell lines, KBM7-SLF N233, KBM7_WT, Dami, HL-60, Jurkat and K-562) was presented. The Compounds 26a-26k showed antiproliferative activity in submicromolar concentration at least for one cell line. The Compound 26c showed strong cytotoxic activity against three $\mathrm{Ba} / \mathrm{F} 3$ cell lines at $\mathrm{IC}_{50}$ values in the range of $0.10-0.24 \mu \mathrm{M}$ and against Dami cell line $\left(\mathrm{IC}_{50}=0.87 \mu \mathrm{M}\right)$. The Compound 26i, with 2-allyloxy substituent, possessed the highest antileukemic activity against Dami, HL-60, Jurkat and K-562 cell lines at submicromolar concentration 0.95, 0.17, 0.10 and 0.18, respectively [40].

Türe et al. described synthesis of thiazolidine-4-one-phenylaminopyrimidine hybrids and tested them for their anticancer activity against chronic myeloid leukemia (K-562), prostate cancer (PC3) and neuroblastoma (SHSY-5Y) cells. Only three compounds (27a-27c) among the series of 42 hybrids showed cell viability\% values less than $50.0 \%$ on K562 cells (Figure 14). The $\mathrm{IC}_{50}$ against K-562 cell line was also determined for these three compounds. The $\mathrm{IC}_{50}$ was $8.79,4.86$ and $9.97 \mu \mathrm{M}$, respectively for Compounds $27 \mathrm{a}, \mathbf{2 7 b}$ and 27c. Additionally apoptosis studies, cell cycle experiments were carried out for 27a-27c. As a results, $27 \mathbf{a}$ and $\mathbf{2 7 b}$ cause mainly early and late apoptosis in K-562 cells in a timedependent manner. In the cell cycle assay, Compounds $27 \mathrm{~b}$ and $27 \mathrm{c}$ arrest G0/G1 phase similar to imatinib (standard), 27a induces cell cycle arrest G2/M phase [41].<smiles>[R2]c1ccc(/C=C2\S/C(=N/c3ccc(C)c(Nc4nccc(-c5cccnc5)n4)c3)N([R7])C2=O)cc1</smiles>

$$
\begin{aligned}
& \text { 27a: } \mathrm{R}=2-\mathrm{F}, \mathrm{R}_{1}=\mathrm{H} \\
& \text { 27b: } \mathrm{R}=4-\mathrm{CF}_{3}, \mathrm{R}_{1}=\mathrm{H} \\
& \text { 27c: } \mathrm{R}=4-\mathrm{OCH}_{3}, \mathrm{R}_{1}=\mathrm{CH}_{3}
\end{aligned}
$$

Figure 14. The thiazolidine-4-one-phenylaminopyrimidine hybrids with antileukemic activity.

The series of isatin-based thiazolidin-4-one derivatives was synthesized and evaluated for their anticancer activity against three cancer cell lines (HepG2, MCF-7 and HT-29). The best activities among the series were found for Compounds 28a and 28b (Figure 15). The Compound 28a was active against HepG2, MCF-7 and HT-29 at half maximal inhibitory concentration of 27.59, 8.97 and $5.42 \mu \mathrm{M}$, respectively. While Compound $\mathbf{2 8 b}$ showed 
comparable activities to standard doxorubicin against all three cancer cell lines. The $\mathrm{IC}_{50}$ were 4.97 vs. $4.50 \mu \mathrm{M}$ (HepG2), 5.33 vs. $4.17 \mu \mathrm{M}$ (MCF-7) and 3.29 vs. $4.01 \mu \mathrm{M}$ (HT-29). Moreover, these compounds showed satisfactory cytotoxicity against fibroblasts (WI-38) at concentration $98.22 \mu \mathrm{M}(\mathbf{2 8 a})$ and $>100 \mu \mathrm{M}$ (28b). Additionally, Compounds $\mathbf{2 8} \mathbf{a}$ and $\mathbf{2 8 b}$ were tested on inhibitory activity against CDK1, p53, caspase-3 and caspase-9. Compounds $\mathbf{2 8 a}$ and $\mathbf{2 8 b}$ exhibited comparable or more potent activity than doxorubicin used as standard (Table 3) [42].
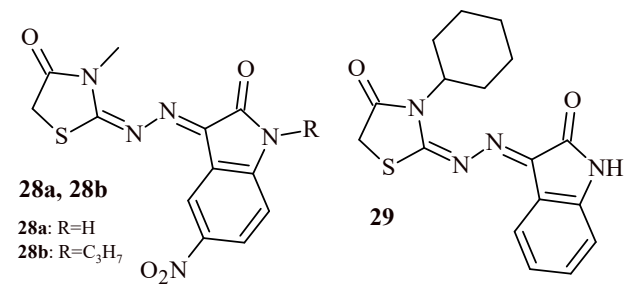<smiles>O=C1CSC(N/N=C\c2c[nH]c3ccccc23)=N1</smiles><smiles>O=C(O)CC1SC(N/N=C\c2c[nH]c3ccccc23)=NC1=O</smiles><smiles>O=C1CSC(NNc2ccnc3cc(Cl)ccc23)=N1</smiles><smiles>O=C(O)CC1SC(NNc2ccnc3cc(Cl)ccc23)=NC1=O</smiles>

Figure 15. The structures thiazolidin-4-one-based indole and quinoline hybrids.

Table 3. Effects of Compounds 28a and $\mathbf{2 8 b}$ on the expression of CDK1, p53, caspase-3 and caspase-9.

\begin{tabular}{ccccc}
\hline \multirow{2}{*}{ Compound } & \multicolumn{4}{c}{ IC $_{\text {50, } \boldsymbol{\mu M} \pm \text { S.E. }}$} \\
\cline { 2 - 5 } & CDK1 & p53 & Caspase-3 & Caspase-9 \\
\hline 28a & $1.13 \pm 0.08$ & $1.07 \pm 0.33$ & $1.19 \pm 0.32$ & $0.93 \pm 0.27$ \\
28b & $0.38 \pm 0.04$ & $3.04 \pm 0.22$ & $5.60 \pm 0.49$ & $3.65 \pm 0.47$ \\
doxorubicin & $0.42 \pm 0.07$ & $2.36 \pm 0.25$ & $3.41 \pm 0.25$ & $4.17 \pm 0.60$ \\
\hline
\end{tabular}

Fouad et al. reported anticancer activity of isatin-based thiazolidin-4-one 29 against renal cell carcinoma. Compound $\mathbf{2 9}$ showed growth inhibition \% of all tested five renal cancer cell lines in the range $59.69-78.46 \%$. The values of half maximal inhibitory concentration were $8.1 \mu \mathrm{M}(\mathrm{A} 498), 17.47 \mu \mathrm{M}(\mathrm{ACHN}), 4.74 \mu \mathrm{M}$ (CAKI-1), $23.57 \mu \mathrm{M}$ (RXF393) and $3.99 \mu \mathrm{M}$ (UO-31). Moreover, Compound 29 showed comparable activity to reference drug sunitinib $\left(\mathrm{IC}_{50}=5.51 \mu \mathrm{M}\right)$ against CAKI-1 renal cancer cell line. In addition, selectivity index of tested compound toward normal renal cell line against five renal cancer lines was in the range of 1.23-7.24. Assays of activity of Compound 29 were performed against angiogenesis promoting enzymes: VEGFR-2, PDGFR $\alpha$ and PDGFR $\beta$. The IC 50 values were at submicromolar concentration $452.53 \mathrm{nM}$ (VEGFR-2), 280.916 nM (PDGFR $\alpha$ ) and $45.013 \mathrm{nM}$ (PDGFR $\beta$ ). In the case of PDGFR $\beta$, enzyme activity was better than sunitinib $\left(\mathrm{IC}_{50}=55 \mathrm{nM}\right)[43]$.

Whereas thiazolidin-4-one derivatives with indole $(30,31)$ and quinoline $(32,33)$ moieties showed weak antiproliferative effect against SF-295, HL-60 and PC3 cell lines. Their reduction of cell viability was less than $40.8 \%$ [44].

Oubella et al. described synthesis and evaluation of carvone-thiazolidin-4-one hybrids with 1,2,3-triazole moiety (34-36) for their anticancer activity against HT-1080, A-549, MCF7 and MDA-MB-231 cell lines. As a result of the study, it was found that Compounds 35b and 35c (Figure 16) exhibited the most potent cytotoxic activity against HT-1080 and A-549 cell lines (Table 4). In the next step of the study, the cell death pathway of the cytotoxic activity of $35 b$ and $35 c$ was investigated. The results suggested that they are capable of inducing apoptosis in a caspase-3 pathway manner and to affecting the cell cycle [45]. 
<smiles>C=C(C)[C@@H]1CC=C(C)/C(=N/N=C2\S/C(=C\c3ccccc3O)C(=O)N2C)C1</smiles><smiles>[R]c1ccc(-n2cc(COc3ccccc3/C=C3\S/C(=N/N=C4\CC(C(=C)C)CC=C4C)N(C)C3=O)nn2)cc1</smiles><smiles>C=C(C)[C@@H]1CC=C(C)/C(=N/N=C2\S/C(=C\c3ccccc3OCc3cn(Cc4ccccc4)nn3)C(=O)N2C)C1</smiles>

35a: $\mathrm{R}=4-\mathrm{CH}$ 35b: $\mathrm{R}=4-\mathrm{F}$ 35c: $\mathrm{R}=2-\mathrm{CH}_{3}, 4-\mathrm{C}$

Figure 16. The thiazolidin-4-one carvone hybrids as anticancer agents.

Table 4. Cytotoxic activity of Compounds 34-36 against HT-1080, A549, MCF-7 and MDA-MB-231 cell lines.

\begin{tabular}{ccccc}
\hline \multirow{2}{*}{ Compound } & \multicolumn{3}{c}{ IC $_{50,} \boldsymbol{\mu M}$} \\
\cline { 2 - 5 } & HT-1080 & A549 & MCF-7 & MDA-MB-231 \\
\hline 34 & 16.93 & 20.13 & 15.56 & 22.02 \\
35a & 17.04 & 19.42 & 25.30 & 27.65 \\
35b & 17.15 & 15.39 & 27.85 & 21.04 \\
35c & 16.60 & 15.04 & 19.89 & 27.87 \\
36 & 18.75 & 23.54 & 19.69 & 28.41 \\
doxorubicin & 4.45 & 5.28 & 6.32 & 5.16 \\
\hline
\end{tabular}

Iqbal and co-worker reported anticancer activity for Compounds $37 \mathrm{a}-37 \mathrm{c}$ as most effective among the series of imidazopyridine-thiazolidin-4-one hybrids (Figure 17). The Compound 37a with para-hydroxy group was found most potent against MCF-7 and DU145 with $\mathrm{IC}_{50}$ values 3.2 and $6.8 \mu \mathrm{M}$, respectively. Whereas Compound $37 \mathrm{~b}$ (5-methyl analogue of 37a) was most effective against $\mathrm{A} 549\left(\mathrm{IC}_{50}=8.4 \mu \mathrm{M}\right)$. The nitro substituted derivative (37c) showed slightly less activity than $37 \mathrm{~b}$ against A549 $\left(\mathrm{IC}_{50}=9.9 \mu \mathrm{M}\right)$. Worth noticing that Compounds $37 \mathrm{a}$ and $37 \mathrm{~b}$ with para-hydroxy group showed additionally antioxidant activity in DPPH assay ( $\mathrm{EC}_{50}$ values of 40.26 and $39.72 \mu \mathrm{M}$, correspondingly) comparable with ascorbic acid used as standard $\left(\mathrm{EC}_{50}=35.62 \mu \mathrm{M}\right)$ [46].

The introducing of quinazoline moiety in Position 3 of thiazolidin-4-one ring decreased cytotoxic activity against A549 and MDA-MB-231 cell lines. The Compounds 38a-38d showed weak cytotoxic effect at concentration in the range of $134.77-153.20 \mu \mathrm{g} / \mathrm{mL}$ [47]. 
<smiles>[R]c1ccc(C2SC([R])C(=O)N2NC(=O)CCC(=O)c2nc3cccnc3[nH]2)cc1</smiles><smiles>[R]C1SCC(=O)N1Nc1ncnc2ccccc12</smiles>

38a-38d<smiles>[X]c1ccc(N2C(=O)CSC2c2ccccc2OOc2ccccc2C2SCC(=O)N2c2ccc([R])cc2)cc1</smiles>

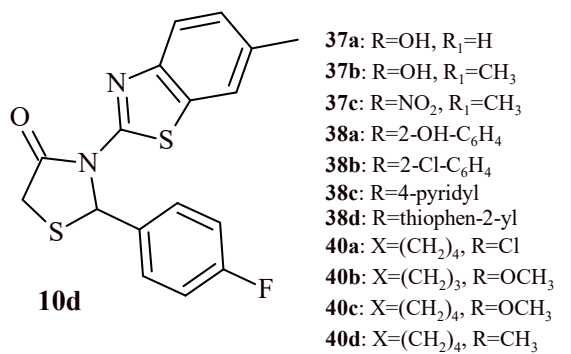<smiles>[R]C(=C)/C=C\C</smiles>

Figure 17. The 2-Aryl-3-aryl/arylaminothiazolidin-4-one derivatives with anticancer activity.

The thiazolidine-4-one derivative (39) with 5-nitrofuran-2-yl substituent exhibited promising anti-breast cancer activity in the in vitro and in vivo tests. The $\mathrm{IC}_{50}$ values for anticancer activity of Compound 39 against human cancer cell lines were $1.9 \mu \mathrm{M}$ (MDAMB-231), $5.4 \mu \mathrm{M}$ (HepG2), $6.5 \mu \mathrm{M}$ (HT-29) and $13.51 \mu \mathrm{M}$ towards normal cell line HGF-1, after treatment for $72 \mathrm{~h}$. In order to establish the mechanism of action of the Compound 39, it carried out series of the tests: induction of cell apoptosis, evaluating the cell cycle progression promoted anchorage-independent growth. In vivo tests were carried out with use of orthotopic breast cancer tumor model on female BALB/c mice. The Compound 39 at Concentration 1 and $10 \mathrm{mg} / \mathrm{kg}$ showed $33 \%$ and $66 \%$ reduction in the tumor growth at termination of experiment. Additionally, it was conducted an assay of Compound 39 on suppress of the metastasis lung. The results showed that Compound 39 contributed to its reduction ( $39.8 \%$ vs. 59.8 in the control group) confirming anti-metastatic effect of Compound 39. The potential activity of Compound 39 is most likely due to induction of apoptosis with G1/S arrest as well as inhibition of angiogenesis [48].

Besides the previously described antioxidant properties of Compound 10d (Figures 5 and 17), this derivative demonstrated dose dependent anticancer activity against Ehrlich ascites carcinoma (EAC) induced peritoneal ascites in mice. The outcomes were comparable to standard 5-fluorouracil [23].

Hebishy et al. presented results of cytotoxic activity of bis-thiazolidin-4-ones (40a-40e and 41a-41c). In Table 5, results of compounds are presented. It shows the best activity of them against HepG2, MCF-7 and Caco-2. Compound 40a was the most effective against 
MCF-7 and Caco-2 cell lines with $\mathrm{IC}_{50}$ values of 22.04 and $45.91 \mu \mathrm{M}$, respectively. The Compound $40 \mathrm{~b}$ was the most active against HepG2 cells $\left(\mathrm{IC}_{50}=34.94 \mu \mathrm{M}\right)$. Generally, ortho substituted derivatives (40a-40e) exhibited better cytotoxic activity than para derivatives (41a-41c) [49].

Table 5. The cytotoxic activity of bis-thiazolidin-4-ones against HepG2, MCF-7 and Caco-2 cell lines.

\begin{tabular}{cccc}
\hline \multirow{2}{*}{ Compound } & & IC $_{\mathbf{5 0}}, \boldsymbol{\mu M}$ & \\
\cline { 2 - 4 } & HepG2 & MCF-7 & Caco-2 \\
\hline 40a & 36.07 & 22.04 & 45.91 \\
40b & 34.94 & 28.49 & 53.97 \\
40d & 61.67 & 33.34 & 47.19 \\
41c & 43.04 & 50.69 & 67.59 \\
doxorubicin & 0.318 & 1.28 & 0.332 \\
\hline
\end{tabular}

Verma et al. synthesized series of thiazolidin-4-one-1,3,4-oxadiazoles (11, 42a-42h) and tested them for anticancer activity against MCF-7, A549 and HeLa cell lines (Figures 7 and 18). The Compound $\mathbf{4 2 d}$ showed noteworthy cytotoxic activity against all three cell lines, MCF-7 $\left(\mathrm{IC}_{50}=0.47 \mu \mathrm{M}\right), \mathrm{A} 549\left(\mathrm{IC}_{50}=0.59 \mu \mathrm{M}\right)$ and HeLa $\left(\mathrm{IC}_{50}=0.53 \mu \mathrm{M}\right)$. These values were comparable to doxorubicin $(0.58,0.72$ and $0.89 \mu \mathrm{M}$, respectively).<smiles>[R]c1ccc2[nH]c(-c3ccccc3)c(C3SCC(=O)N3c3nnc(Sc4nc5c6cc([R])ccc6[nH]c5c5ccccc45)o3)c2c1</smiles>

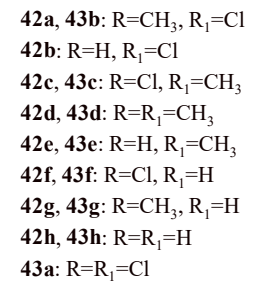<smiles>[R]c1ccc2[nH]c(-c3ccccc3)c(C3=C(C#N)C(N4C(=O)CSC4c4c(-c5ccccc5)[nH]c5ccc([Z13])cc45)NC(c4ccccc4)=C3)c2c1</smiles>

Figure 18. The structures of a series of thiazolidin-4-one-1,3,4-oxadiazoles (42a-42h) and thiazolidin4-one with indolyl-pyridine moiety (43a-43h).

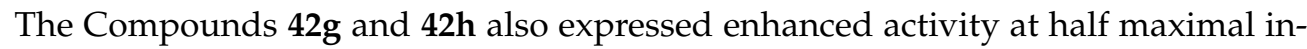
hibitory concentration of 1.54 and $1.82 \mu \mathrm{M}$ (MCF-7), 1.78 and $1.85 \mu \mathrm{M}$ (A549), 1.56 and $1.80 \mu \mathrm{M}$ (HeLa). The other compounds showed moderate effect $(42 \mathrm{a}-42 \mathrm{c})$ or were inactive (Compound 11, Figure 7) [25]. Similar results were obtained also for series of Compound 12 and $\mathbf{4 3 a}-\mathbf{4 3 h}$ (Figures 7 and 18). The most effective Derivative $\mathbf{4 3 d}$ showed activity against three cell lines at concentration $0.45 \mu \mathrm{M}$ (MCF-7), $0.53 \mu \mathrm{M}$ (A549) and $0.52 \mu \mathrm{M}$ (HeLa) [26].

Zhou et al. described assessing of the quinoline-based 2-(2,6-difluorophenyl)-thiazolidin4-one derivatives as kinase inhibitors for the treatment of colorectal cancer [50,51]. Among the fifteen derivatives, identified the most active Compound 44 showed cytotoxic activity against HT-29 cell line at $\mathrm{IC}_{50}$ value $0.31 \pm 0.022 \mu \mathrm{M}$ (Figure 19). Furthermore, 44 inhibited tyrosine-protein kinase Met (c-Met) and Ron tyrosine kinase in 65 and $84.4 \%$ with $\mathrm{IC}_{50}$ values 0.382 and $0.122 \mu \mathrm{M}$, respectively. The thio analogue of 44 , Compound 45 , showed slightly less activity against HT-29 cells $\left(\mathrm{IC}_{50}=0.42 \pm 0.031 \mu \mathrm{M}\right)$, while maintaining a similar level of kinases inhibition (62.9\%—c-Met; $83 \%$-Ron). The homologue of 44, Compound 46, exhibited similar level of kinases inhibition (58.4\% — c-Met; $86.1 \%$ - Ron) and cytotoxic effect against HT-29 cells $\left(\mathrm{IC}_{50}=0.39 \pm 0.028 \mu \mathrm{M}\right)$. These results were more potent than same for standard drugs regorafenib $\left(\mathrm{IC}_{50}=2.87 \pm 0.18 \mu \mathrm{M}\right.$ against HT-29) and cabozantinib $\left(\mathrm{IC}_{50}=10.6 \pm 1.12 \mu \mathrm{M}\right.$ against HT-29) [50] 

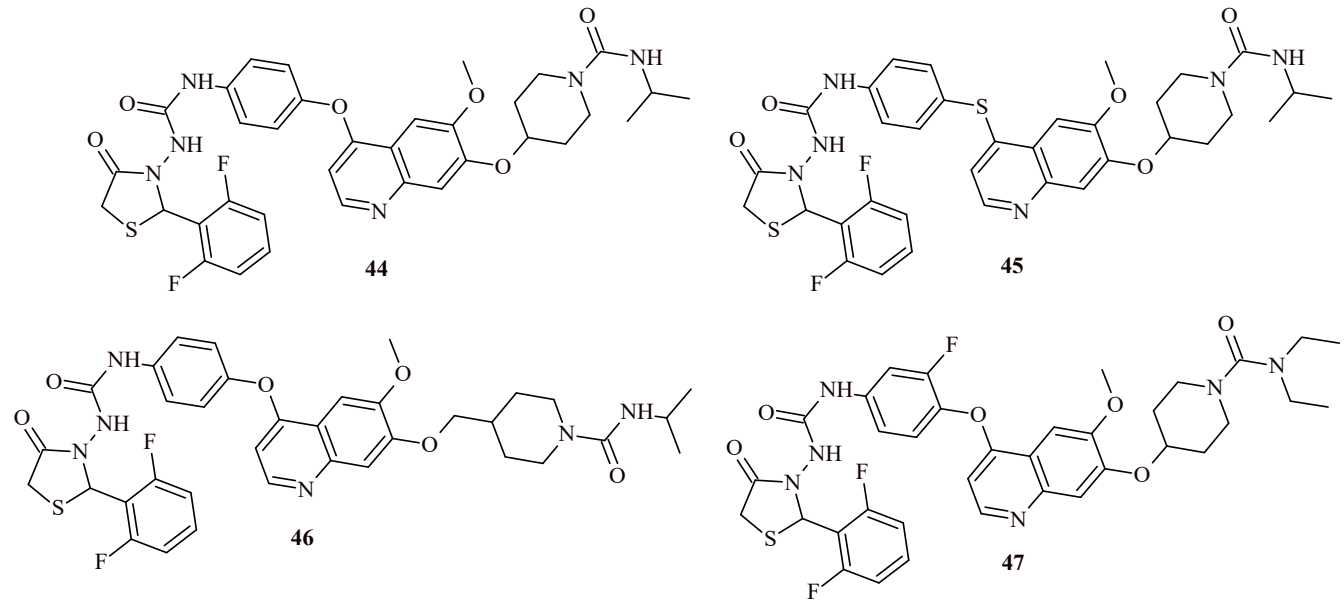

Figure 19. The structures of quinoline-based 2-(2,6-difluorophenyl)-thiazolidin-4-one derivatives as kinase inhibitors for the treatment of colorectal cancer.

The modification of ureidophenoxyl and piperidine-1-carboxamide moieties by 2fluoro and diethyl substituents led to obtaining more effective (Compound 47) anticolorectal cancer agent than Compound 44. The $\mathrm{IC}_{50}$ value of 47 was $0.19 \pm 0.012 \mu \mathrm{M}$, \% of inhibition was 76.3 and 89.3 against c-Met and Ron kinases [51].

Kobylinska et al. reported anticancer activity of Les-3833 comparable to doxorubicin against human glioma and rat glioma cells as well as human melanoma cell lines (Figure 20). Their $\mathrm{IC}_{50}$ were $0.84 \pm 0.09$ (Les-3833) vs. $0.90 \pm 0.11$ (doxorubicin) $\mu \mathrm{g} / \mathrm{mL}$ (U251), $0.89 \pm 0.12$ vs. $0.84 \pm 0.08 \mu \mathrm{g} / \mathrm{mL}$ (C6), $0.22 \pm 0.03$ vs. $0.24 \pm 0.05 \mu \mathrm{g} / \mathrm{mL}$ (WM793) and $0.30 \pm 0.04$ vs. $0.35 \pm 0.06 \mu \mathrm{g} / \mathrm{mL}$ (SK-MEL-28) [52]. Moreover, in silico studies of Les3833 showed the affinity to topoisomerase II inhibitor, and high possibility for inhibitory interaction with ChekPoint kinase-1, caspase-6 and caspase-8 [53].

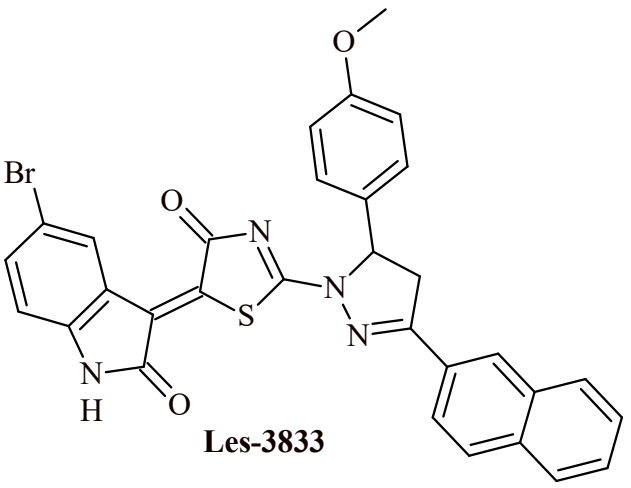

Figure 20. The structures of thiazolidin-4-one-based derivative Les-3833.

The studies conducted by Shawky et al. concern to anticancer activity of pyrrolizinethiazolidin-4-one derivatives (48a-48c and 49) (Figure 21) [54]. The cytotoxicity was evaluated by the MTT assay. The results displayed potential cytotoxic activity with $\mathrm{IC}_{50}$ values in the range of 0.11-4.24 $\mu \mathrm{M}$, toward three cancer cell lines (MCF-7, A2780 and HT-29). Among the pyrrolizine-thiazolidin-4-one hybrids (48a-48c and 49), Compound 48a showed highest anticancer potential against breast cancer cell line (MCF-7) with $\mathrm{IC}_{50}=0.16 \pm 0.08 \mu \mathrm{M}$. While Compound $48 \mathrm{~b}$ was the most active against $\mathrm{A} 2780\left(\mathrm{IC}_{50}=0.11 \pm 0.01 \mu \mathrm{M}\right)$ and HT$29\left(\mathrm{IC}_{50}=0.12 \pm 0.03 \mu \mathrm{M}\right)$. The Compounds $48 \mathrm{a}-48 \mathrm{c}$ and 49 were also evaluated for their selectivity toward normal MRC5 cells. Generally, pyrrolizine-thiazolidin-4-one derivatives exhibited selectivity index (SI) in the range of 3-15 against MCF-7 and A2780 cell lines. The Compound 49 showed the highest selectivity against all three cell lines ( $\mathrm{SI}=2.62$ for A2780 cells, SI = 5.39 for HT-29 and SI = 13.21 for MCF-7cells). 
<smiles>[R]c1ccc(NC(=O)c2c(N3C(=O)CSC3CC)c(C#N)c3n2CCC3)cc1</smiles><smiles>CCC1SCC(=O)N1c1c(C#N)c2n(c1C(=O)Nc1ccccc1)CCCC2</smiles>

48a: $\mathrm{R}=\mathrm{H}, 48 \mathrm{~b}: \mathrm{R}=\mathrm{CH}_{3}, 48 \mathrm{c}: \mathrm{R}=\mathrm{Cl}$

Figure 21. Pyrrolizine-thiazolidin-4-one derivatives with anticancer activity.

Lesyk et al. synthesized series of ciminalum-rhodanine hybrids and conducted screening of obtained compounds for their antitumor activity according to the NCI DTP (USA) standard protocol at the concentration in the range $10^{-4}-10^{-8} \mathrm{M}$ against 60 tumor cell lines [55]. The results of screening of ciminalum-rhodanine hybrids confirmed their significant anticancer properties. Compounds 50 and 52 (Figure 22) showed growth inhibition of all tested tumor cell lines at submicromolar and micromolar concentrations. Worth noticing that the most active Compound 52 was active with $\mathrm{GI}_{50}$ concentration in the range of $<0.01-0.02 \mu \mathrm{M}$ against following cell lines: MOLT-4, SR (leukemia), SW-620 (colon cancer), SF-539 (CNS cancer), SK-MEL-5 (melanoma). Based on SAR analysis, authors note that the presence of ciminalum moiety turned out to be essential for achievement of the anticancer activity. Furthermore, nature of substituents at Position 3 of thiazolidinone ring is important. Thus, compounds with 4-hydroxyphenyl substituent (50) and carboxylic acid residue $(\mathbf{5 1}, \mathbf{5 2})$ were most active against cancer cell lines.<smiles>O=C1/C(=C/C(Cl)=C/c2ccc([N+](=O)[O-])cc2)SC(=S)N1c1ccc(O)cc1</smiles><smiles>O=C(O)C(Cc1ccccc1)N1C(=O)/C(=C/C(Cl)=C/c2ccc([N+](=O)[O-])cc2)SC1=S</smiles><smiles>O=C(O)CCN1C(=O)/C(=C/C(Cl)=C/c2ccc([N+](=O)[O-])cc2)SC1=S</smiles><smiles>O=C(O)CCCCCN1C(=O)/C(=C/C(Cl)=C/c2ccc([N+](=O)[O-])cc2)SC1=S</smiles>

Figure 22. The ciminalum-rhodanine hybrids with anticancer properties. 
In the next stage of the research, obtained hybrids were evaluated for their anticancer activity against AGS (gastric cancer), DLD-1 (human colon cancer), MCF-7 and MDAMB-231 (breast cancers) by MTT assay. The most effective were Compounds 52 and 53 with propanoic and hexanoic acids residue at Position 3 of rhodanine ring, respectively. Their GI $_{50}$ values were as follows: for Compound 52-2.69 $\mu \mathrm{M}$ (AGS), 3.67 $\mu \mathrm{M}$ (DLD-1), $3.62 \mu \mathrm{M}$ (MCF-7) and $1.63 \mu \mathrm{M}$ (MDA-MB-231); for Compound 53-3.20 $\mu \mathrm{M}$ (AGS), $9.22 \mu \mathrm{M}$ (DLD-1), $1.73 \mu \mathrm{M}$ (MCF-7) and $0.95 \mu \mathrm{M}$ (MDA-MB-231). These results were consistent with previously obtained data according to NCI DTP protocol for breast cancers cell lines. Moreover, Compounds 50-53 had low toxicity toward normal human blood lymphocytes $\left(\mathrm{GI}_{50}\right.$ values of $48.97 \mu \mathrm{M}$ (51), $54.54 \mu \mathrm{M}$ (52) and $100 \mu \mathrm{M}$ (50 and 53)). Summarizing, the important role of the ciminalum substituent in Position 5 and the nature of substituent in Position 3 (preferable carboxylic acid residue) of the rhodanine ring for anticancer activity was established.

In the next study the evaluation of cytotoxic potential of a series rhodanine- $N$ arylsuccinimid hybrids (19 compounds) against four leukemic cell lines (Dami, HL-60, Jurkat and K-562) was conducted [56]. Among the all-tested compounds, only Derivatives $\mathbf{5 4 a}-\mathbf{5 4 c}$ and 55 (Figure 23) showed \% of growth inhibition more than $50 \%$ at concentration $10 \mu \mathrm{M}$ against Dami cell line.
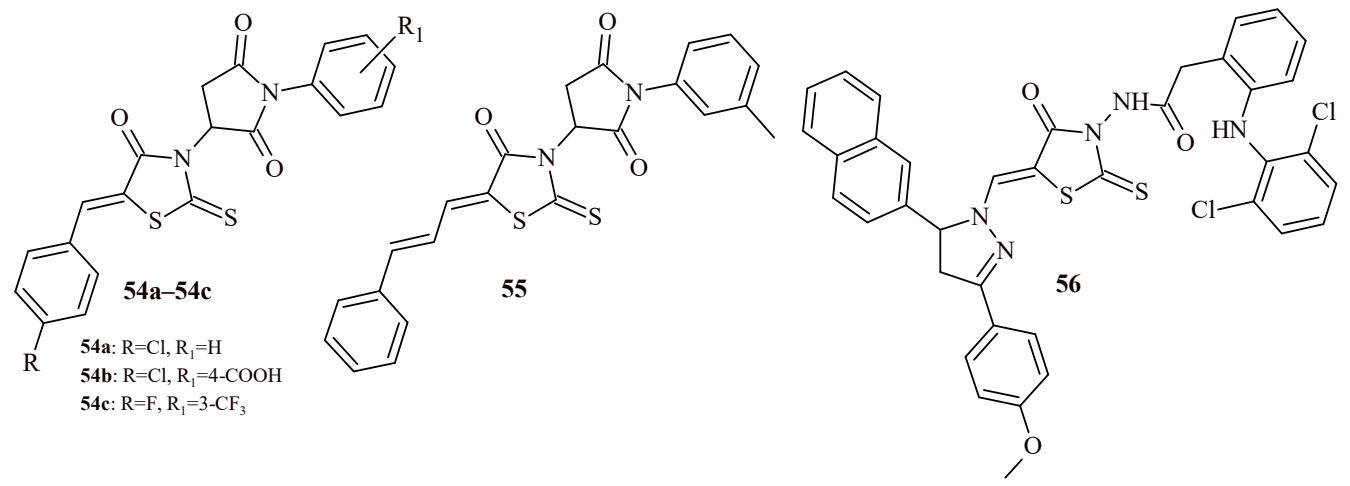

Figure 23. The structures of rhodanine- $N$-arylsuccinimid and rhodanine-pyrazoline hybrids.

The study conducted by Shepeta et al. showed that rhodanine-pyrazoline hybrid with diclofenac moiety (56) had high effectiveness against 60 cancer cell lines (NCI DTP protocol) with a mean of $\mathrm{GI}_{50}=0.71 / 1.09 \mu \mathrm{M}$ and TGI $=82.95 / 28.46 \mu \mathrm{M}$ [57].

Tilekar et al. described series of 5-(naphtha-2-ylidene)thiazolidine-2,4-dione derivatives as simultaneously target PPAR $\gamma$ and HDAC (Figure 24). The reports [58-60] suggested that combination treatment with PPAR $\gamma$ agonists and HDAC inhibition increased cytotoxic activity against various cancer cell lines. Basing on these observations, authors designed, synthesized assessed of compounds that can be target PPAR $\gamma$ and HDAC simultaneously. Among the 25 compounds (57-60), several of them inhibited HDAC4 (57l, 58a and 59c) and six compounds (57c, 57i, 571, 57m, 57o and 57p) showed dual inhibition activity. Compound 58a with benzothiazole moiety was most active against HDAC4 $\left(\mathrm{IC}_{50}=0.42 \pm 0.05 \mu \mathrm{M}\right)$. Compound 58a was the most effective also against HDAC8 $\left(\mathrm{IC}_{50}=2.7 \pm 0.2 \mu \mathrm{M}\right)$. The most potent partial PPAR $\gamma$ agonist were 57i and 571 with $\mathrm{EC}_{50}$ values of $0.245 \pm 0.006 \mu \mathrm{M}$ and $0.359 \pm 0.031 \mu \mathrm{M}$, correspondingly. The Compound $57 \mathbf{i}$ was found to be most effective with dual activity $\left(\mathrm{EC}_{50}=0.245 \mu \mathrm{M}\right.$ and $\left.\mathrm{IC}_{50}=1.1 \mu \mathrm{M}\right)$. Moreover, Compounds 57c and 57i showed cytotoxicity against CCRFCEM cells $\left(\mathrm{CC}_{50}=2.8\right.$ and $9.6 \mu \mathrm{M}$, respectively), as well as they induced apoptosis and caused DNA fragmentation. Additionally, Compound 57c caused in vivo tumor regression in CCRF-CEM tumor xenografts [61]. 


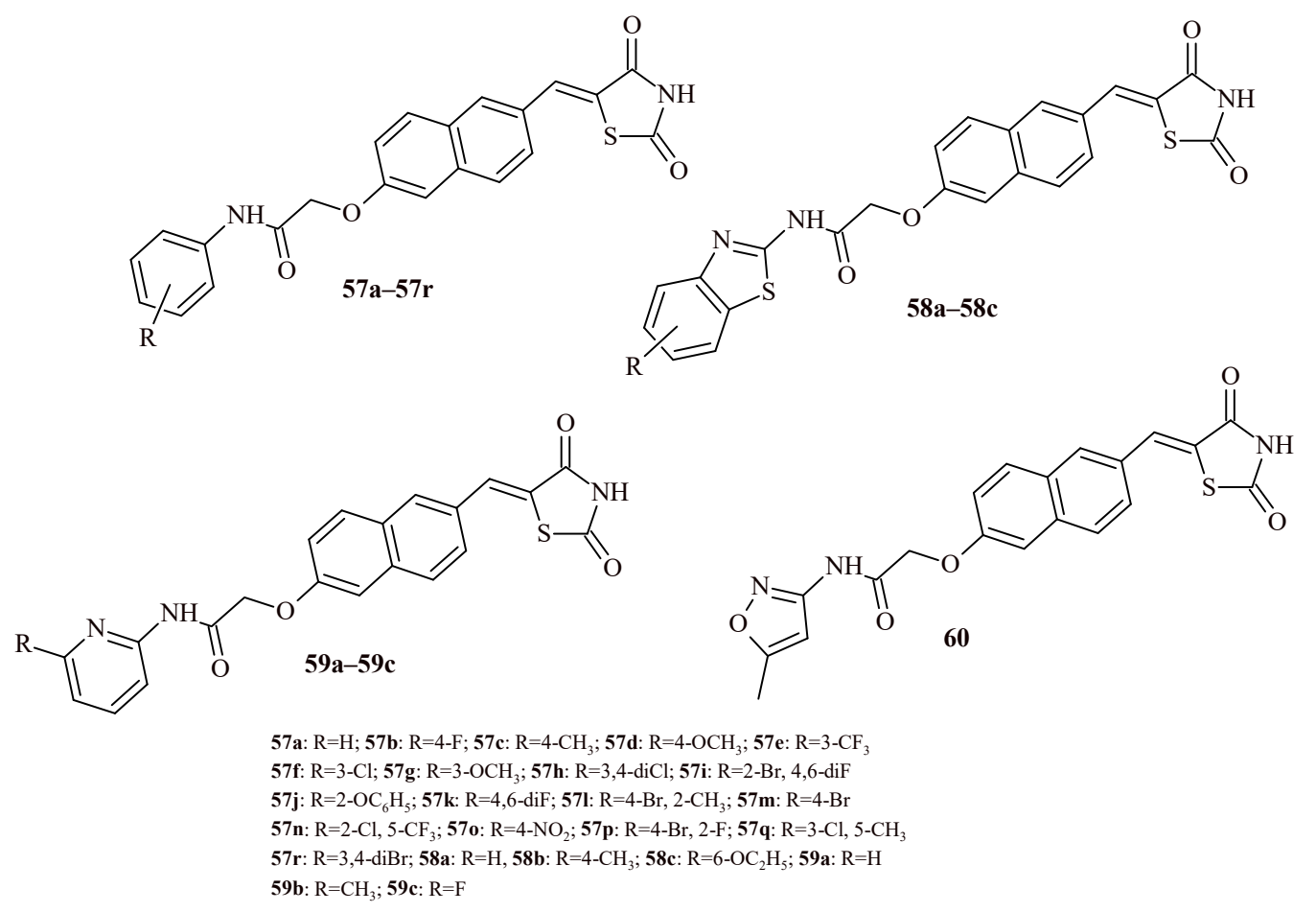

Figure 24. The structures of thiazolidine-2,4-dione derivatives with PPAR $\gamma$ and HDAC target simultaneously.

\subsection{Anti-Inflammatory and Analgesic Properties}

The above-mentioned Compounds $48 \mathrm{a}-\mathbf{4 8 c}$ and 49 with anticancer activity were additionally tested for their anti-inflammatory activity as well as COX inhibitory activity (Figure 21) [54]. Compound 48c showed only $21.76 \%$ inhibition of edema ( $2 \mathrm{~h}$ post-carrageenan) and $32.48 \%$ inhibition of edema ( $4 \mathrm{~h}$ post-carrageenan) it was worse than standard celecoxib (36.96\% and $67.37 \%$, respectively) and indomethacin $(32.30 \%$ and $56.39 \%$, respectively), whereas, high selectivity for COX-2 showed Compounds $48 \mathrm{~b}$ and 48c. The Compounds $48 \mathrm{~b}$ and $48 \mathrm{c}$ inhibited COX-2 with $\mathrm{IC}_{50}=1.25 \mu \mathrm{M}$ and $1.15 \mu \mathrm{M}$, correspondingly. The inhibitory activity of these both derivatives (48b and 48c) towards COX-1 was $>100 \mu \mathrm{M}$. Thus, their SI were $>80$ and $>86$, correspondingly.

Vasincu et al. carried out evaluation of ibuprofen derivatives with thiazolidine-4-one scaffold (61a-61n) for their anti-inflammatory and analgesic activities (Figure 25) [62]. The carrageenan-induced paw edema assay was used to assess the anti-inflammatory effect. Additionally, the analgesic effect was verified by the tail-flick assay and the writhing test. First of all, acute toxicity on rat model was evaluated for all compounds (61a-61n). These compounds were less toxic than the reference drug-ibuprofen $\left(\mathrm{LD}_{50}=1375 \mathrm{mg} / \mathrm{kg} \mathrm{b.w.}\right)$ with $\mathrm{LD}_{50}$ values in the range of $1565-1840 \mathrm{mg} / \mathrm{kg}$ b.w. The results suggested that tested derivatives were practically non-toxic. The effects of the carrageenan-induced paw edema assay were measured at regular intervals $(2 \mathrm{~h}, 4 \mathrm{~h}, 6 \mathrm{~h}$ and $24 \mathrm{~h})$. The compounds were tested at a dose of $1 / 20 \mathrm{LD}_{50}$ and the results are expressed as edema inhibition (\%). At

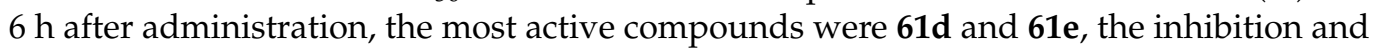
percentages of paw edema were $65.71 \pm 10.49 \%$ and $60.81 \pm 8.49 \%$, that were higher than ibuprofen value $(43.67 \pm 5.20 \%)$. Analysis of the data recorded $24 \mathrm{~h}$ after administration showed a long-lasting anti-inflammatory effect of the obtained compounds, for some even higher than that of reference drug ibuprofen. The most active of them was 61d (with 4-fluorophenyl substituent), with an edema inhibition value of $53.04 \pm 13.17 \%$. 


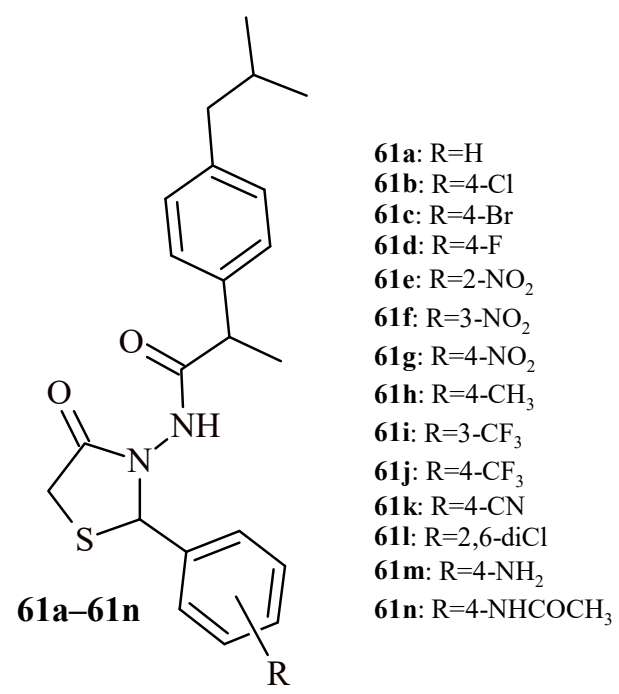

Figure 25. Ibuprofen-thiazolidin-4-one hybrids with anti-inflammatory and analgesic activities.

The highest analgesic activity in tail-flick assay showed Compounds $61 \mathrm{~m}(75.67 \pm 5.94 \%)$, 61k $(75.36 \pm 3.08 \%)$ and $61 \mathrm{~h}(74.45 \pm 6.06 \%)$. The pain-inhibiting effects were higher than for ibuprofen $(67.15 \pm 8.66 \%)$. Among the tested compounds, the Derivatives $61 n(69.59 \pm 5.56 \%)$, $61 \mathrm{i}(68.37 \pm 4.70 \%), 61 \mathrm{e}(63.50 \pm 6.49 \%)$ showed ibuprofen-like activity. The analgesic effect for the writhing assay was a measure of writhing episode number and it was expressed numerically. In this test, the activity of the synthesized derivatives was between $23.38 \pm 1.45 \%$ to $56.37 \pm 10.30 \%$. For comparison, the registered value for ibuprofen was $52.37 \pm 10.33 \%$. The higher than the reference drug analgesic effect was demonstrated by the Compounds $61 \mathrm{~h}$ $(56.37 \pm 10.30 \%)$ and $61 e(53.06 \pm 10.63 \%)$.

The highest therapeutic potential was shown in compounds named $61 \mathrm{~d}, 61 \mathrm{e}, 61 \mathrm{k}$ and $61 \mathrm{~m}$. It can be concluded that the presence of the trifluoromethyl group in the 4 position (61j) and the nitro group in the 2 or 4 positions (61e and $61 \mathrm{~g}$ ) reduces toxicity and thus improves the safety profile of drugs. The compounds substituted with methyl (61h), cyano $(61 \mathrm{k})$, amino $(61 \mathrm{~m})$ groups in the para position showed the strongest analgesic effect, but it was higher than activity of ibuprofen. The derivative which has a fluorine atom in its structure in the para position (61d) had the highest anti-inflammatory activity in the edema inhibition test (Figure 26).

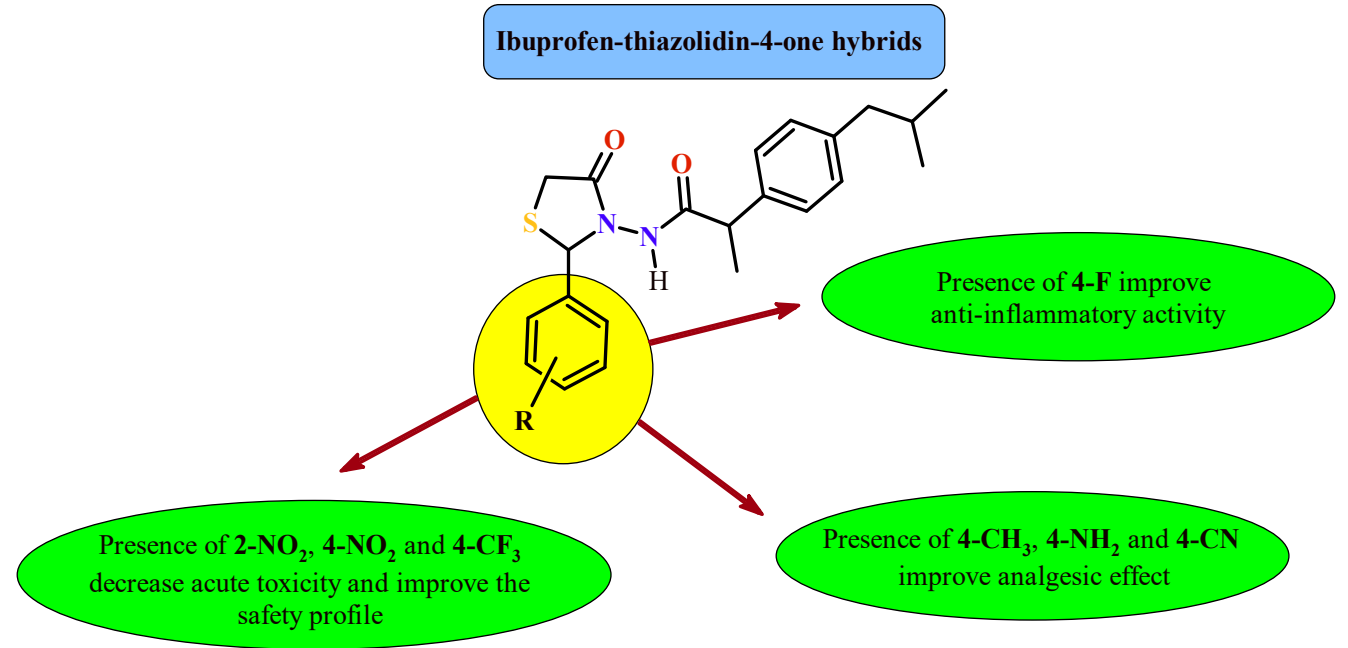

Figure 26. The influence of benzene ring substitution for activity potential of ibuprofen-thiazolidin-4one hybrids. 
Among the 2-aryl-3-(naphtha-2-yl)thiazolidin-4-one derivatives described by Agrawal et al. the compounds (62a-62c) with chloro, fluoro and nitro substituents respectively showed most potent anti-inflammatory activity in carrageenan-induced paw edema test in rats (Figure 27). Besides, these derivatives were found to be the most potent also as analgesic agents in tail immersion and writhing tests in mice [63].<smiles>[R]c1ccc(C2SCC(=O)N2c2cccc3ccccc23)cc1</smiles><smiles>CC1=CCC(CC2SCC(=O)N2CCCN2CCOCC2)C1(C)C</smiles><smiles>CCCCCCCCC1SCC(=O)N1Cc1ccco1</smiles>

64

$62 a-62 c$

62a: $\mathrm{R}=\mathrm{Cl}$

62b: $\mathrm{R}=\mathrm{F}$

62c: $\mathrm{R}=\mathrm{NO}_{2}$

Figure 27. The structure of various 2-aryl/alkylthiazolidin-4-ones with potential anti-inflammatory and analgesic activity.

The Compound 63 with campholenic aldehyde residue in structure (Figure 27) at a dose of $100 \mathrm{mg} / \mathrm{kg}$ showed significant protection against indometacin-induced ulceration. It antiulcerative activity score (5.2) was higher than the same for reference drug omeprazole (3.8). Furthermore, Compounds $\mathbf{6 3}$ and $\mathbf{6 4}$ at a dose of $100 \mathrm{mg} / \mathrm{kg}$ had anti-inflammatory effects similar to standard diclofenac in histamine-induced inflammatory edema [64].

Omar et al. carried out evaluation of 31 thiazolidin-4-one-1,3,4-thiadiazole hybrids (65-71) for their activity towards 15-LOX and COX enzymes (Figure 28). Some of them were also tested for anti-inflammatory activity in vivo. The Compounds 65 and 66 a were most active against 15-LOX with $\mathrm{IC}_{50}$ values of 2.74 and $2.54 \mu \mathrm{M}$, respectively. In the arylidene series (67a-67r), Compound 67a with 4-methyl group showed the highest activity $\left(\mathrm{IC}_{50}=3.11 \mu \mathrm{M}\right)$. Increasing the length of aliphatic substituent $(67 \mathrm{~b}, 67 \mathrm{c})$ decrease the activity $\left(\mathrm{IC}_{50}=5.24\right.$ and $8.33 \mu \mathrm{M}$, respectively). The Compound 67e with 2-hydroxy group was more active than 4-hydroxy isomer $67 \mathrm{~d}\left(\mathrm{IC}_{50}\right.$ values of $\left.4.21 \mathrm{vs.} 5.47 \mu \mathrm{M}\right)$. Increasing the number of hydroxy groups decreased inhibitory activity (67f). Similar trends could be observed for derivatives with methoxy groups $(67 \mathrm{~g}, 67 \mathrm{~h}$ and $67 \mathrm{i})$ [65].

All tested compounds (65-71) exhibited inhibitory potential against COX-2 at concentration in the range of $0.1-0.42 \mu \mathrm{M}$ and selectivity index ranging from 12.44 to 151.10 . The high selective compounds were $\mathbf{6 7} \mathbf{r}, \mathbf{6 7} \mathbf{i}, \mathbf{6 7} \mathbf{q}$ and $\mathbf{6 7} \mathbf{f}$ with SI of $151.10,123.40,114.20$ and 103.82, respectively. In addition, these derivatives showed higher activity against COX-2 than diclofenac. Basing on SAR analysis, authors determined that presence of bulky substituent (4-bromo or 3,4,5-trimethoxyphenyl) is required at Position 5 of thiazolidine ring for good activity and selectivity.

Selected compounds $(\mathbf{6 5}, \mathbf{6 7 f}, \mathbf{6 7 i}, \mathbf{6 7 q}$ and $\mathbf{6 7} \mathrm{r})$ were evaluated for their anti-inflammatory activity in vivo used carrageenan-induced paw edema model in rats. All the tested compounds at a dose $28 \mu \mathrm{g} / \mathrm{kg}$ showed maximal activity $3 \mathrm{~h}$ after administration comparable to the reference drug celecoxib. The most active compounds $(65,67 q$ and $67 \mathrm{r})$ showed percent of inhibition of edema $49.5,60.7$ and $57.9 \%$, respectively [65]. 
<smiles>Cc1nnc(/N=C2/NC(=O)CS2)s1</smiles>

65<smiles>O=C1CS/C(=N/c2nnc(-c3ccc(P)cc3)s2)N1</smiles>

66a-66h<smiles>Cc1nnc(/N=C2\NC(=O)/C(=C/c3cccnc3)S2)s1</smiles><smiles></smiles><smiles>[R]c1ccc(C=C(C)CO)cc1</smiles><smiles>CCC</smiles><smiles>Cc1nnc(/N=C2\NC(=O)/C(=C/c3ccsc3)S2)s1</smiles><smiles>Cc1nnc(/N=C2\NC(=O)/C(=C/C=C/c3ccccc3)S2)s1</smiles>

66a: $\mathrm{R}=\mathrm{H} ; \mathbf{6 6 b}, \mathbf{6 7 e}: \mathrm{R}=2-\mathrm{OH} ; \mathbf{6 6 c}, \mathbf{6 7 d}: \mathrm{R}=4-\mathrm{OH} ; \mathbf{6 6 d}, \mathbf{6 7} \mathbf{a}: \mathrm{R}=4-\mathrm{CH}_{3}$ 66e, 67q: $\mathrm{R}=4-\mathrm{Br} ; \mathbf{6 6 f}, \mathbf{6 7}$ : $\mathrm{R}=4-\mathrm{OCH}_{3} ; \mathbf{6 6 g}, \mathbf{6 7 h}: \mathrm{R}=3,4-\mathrm{diOCH}_{3}$ 66h, 67i: $\mathrm{R}=3,4,5$-triOCH 3 ; 67b: $\mathrm{R}=4-\mathrm{C}_{3} \mathrm{H}_{7} ; 67 \mathbf{c}: \mathrm{R}=4-\mathrm{CH}\left(\mathrm{CH}_{3}\right) \mathrm{CH}_{3}$ 67f: $\mathrm{R}=3,4-\mathrm{diOH} ; \mathbf{6 7 j}: \mathrm{R}=4-\mathrm{OH}, 3-\mathrm{OCH}_{3} ; \mathbf{6 7} \mathbf{k}: \mathrm{R}=4-\mathrm{N}\left(\mathrm{CH}_{3}\right)_{2}$ 67l: $\mathrm{R}=4-\mathrm{Cl} ; \mathbf{6 7} \mathbf{m}: \mathrm{R}=3-\mathrm{Cl} ; \mathbf{6 7 n}: \mathrm{R}=2-\mathrm{Cl} ; \mathbf{6 7 0}: \mathrm{R}=2,4-\mathrm{diCl} ; \mathbf{6 7 p}$ : R=3,4-diCl 67r: $\mathrm{R}=2,3,4,5,6$-pentaF

Figure 28. The structures of thiazolidin-4-one-1,3,4-thiadiazole hybrids with dual COX-2 and 15-LOX anti-inflammatory activity.

The series of 5-arylidenethiazolidin-4-ones with pirazole moiety was tested for their anti-inflammatory activity with use of carrageenan-induced rat paw edema test. Eight compounds (72a-72h) showed the most potent activity at the 4 th $\mathrm{h}$ post administration (Figure 29). The percents of edema inhibition were $98.16 \%$ (72g), 96.73\% (72c), 88.81\% (72d), 81.5\% (72a), 76.68\% (72e), 76.17\% (72h), 73.82\% (72f) and 71.8\% (72b). It is worth noticing, that Compound $72 \mathrm{~g}$ with 2-thienyl substituent showed higher edema inhibition percentage compared to all reference drugs, which were used in the test: indomethacin $(96.94 \%)$, diclofenac $(73.86 \%)$ and celecoxib $(73.40 \%)$.<smiles>[R]C=C1SC(=N/N=C\c2cn(-c3ccccc3)nc2-c2ccccc2)NC1=O</smiles>

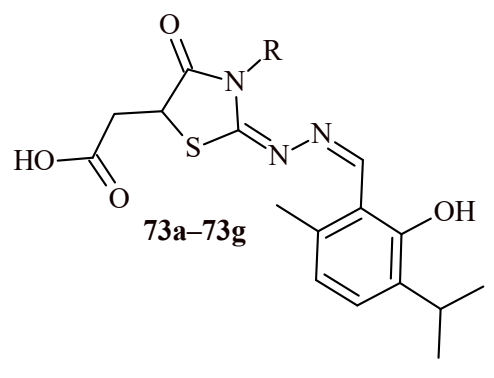

72a: $\mathrm{R}=4-\mathrm{CH}_{3}-\mathrm{C}_{6} \mathrm{H}_{4}$

72b: $\mathrm{R}=3,4,5-$ triOCH$_{3}-\mathrm{C}_{6} \mathrm{H}_{2}$

72c: $\mathrm{R}=2-\mathrm{OH}-\mathrm{C}_{6} \mathrm{H}_{4}$

72d: $\mathrm{R}=4-\mathrm{Cl}-\mathrm{C}_{6} \mathrm{H}_{4}$

72e: $\mathrm{R}=2,4-\mathrm{diCl}-\mathrm{C}_{6} \mathrm{H}_{3}$

72f: $\mathrm{R}=2$-naphthyl

72g: $\mathrm{R}=2$-thienyl

72h: $\mathrm{R}=4$-pyridyl

73a: $\mathrm{R}=\mathrm{C}_{6} \mathrm{H}_{5}$

73b: $\mathrm{R}=2-\mathrm{Cl}-\mathrm{C}_{6} \mathrm{H}_{4}$

73c: $\mathrm{R}=2$-pyridyl

73d: $\mathrm{R}=4-\mathrm{OCH}_{3}-\mathrm{C}_{6} \mathrm{H}_{4}$

73e: $\mathrm{R}=1$-naphthyl

73f: $\mathrm{R}=\mathrm{C}_{2} \mathrm{H}_{5}$

73g: $\mathrm{R}=\mathrm{H}$

Figure 29. Thiazolidin-4-one derivatives containing pyrazole and thymol moieties with antiinflammatory activity.

Selected derivatives were tested for their analgesic activity and the ability to inhibit the production of the inflammatory cytokine TNF $\alpha$ in serum. The results showed, that tested compounds (72a, 72c, 72d and 72h), except $\mathbf{7 2 d}$, had rapid analgesia 30 min after administration as well as long analgesic effect for $90 \mathrm{~min}$ after administration. ELISA assay demonstrated that compounds (72a, 72c, 72d and 72h) had ability to inhibit cytokine TNF $\alpha$ in mice sera in comparison reference drugs [66].

Presented in Figure 29 Compounds $\mathbf{7 3 a - 7 3 g}$ showed multitarget inhibitory activity against COX-2, 5-LOX and PIM-1 kinase enzymes that are key for colorectal cancer treatment. The Compounds $\mathbf{7 3 a - 7 3 d}$ showed high or equal activity and selectivity against COX-2 $\left(\mathrm{IC}_{50}=0.037-0.058 \mu \mathrm{M} ; \mathrm{SI}=203.6-378\right)$ in comparison to reference drug celecoxib 
$\left(\mathrm{IC}_{50}=0.045 \mu \mathrm{M} ; \mathrm{SI}=327\right)$. The most active against COX-2 as well as 5-LOX was Compound 72d ( $\mathrm{IC}_{50}$ values of 0.037 and $2.81 \mu \mathrm{M}$, respectively). Formalin-induced paw edema test indicated, that Compounds $\mathbf{7 3 a}, 73 \mathrm{f}$ and $\mathbf{7 3 g}$ showed excellent anti-inflammatory activity compared to both reference drug diclofenac and celecoxib. Percents of edema inhibition were in the range of 53.90-72.23\%. In vitro anticancer screening showed that Compounds 73d, 73e and $\mathbf{7 3 g}$ were most active against human colon cancer cell lines (Caco-2 and HCT116) at ranges of concentration $0.051-0.114$ and $0.06-0.109 \mu \mathrm{M}$, respectively. These compounds (73d, 73e and 73g) were tested to their ability to inhibit PIM-1/2 kinase enzymes. All compounds showed high inhibitory activity against PIM-1 and PIM-2 kinases. Compound 73g was most effective against PIM-1 kinase $\left(\mathrm{IC}_{50}=2.962 \mu \mathrm{M}\right)$, and Compound 73d was the most active against PIM-2 kinase $\left(\mathrm{IC}_{50}=0.976 \mu \mathrm{M}\right)$. The docking studies in the active site of target enzymes were supported by the biological results. In conclusion, Compound $\mathbf{7 3 g}$ was found as effective inhibitor of three targets that lead to inhibition of human colorectal cancer cell proliferation [67].

There is also report of evaluation of anti-inflammatory activity of series rhodaninediclofenac hybrids (Figure 30). Evaluation of anti-inflammatory activity, with use of carrageenan-induced rat paw edema test, indicated, that Compound $\mathbf{7 4 b}$ showed no significant decreased of edema, whereas Compounds 74a, 74c and 74d exhibited antiinflammatory activity in the range of $39.5-40.8 \%$ of edema inhibition. It was comparable to reference drugs diclofenac and ketorolac. The most active was Compound 74c with 4-fluorophenyl substituent in Position 3 of rhodanine [68].

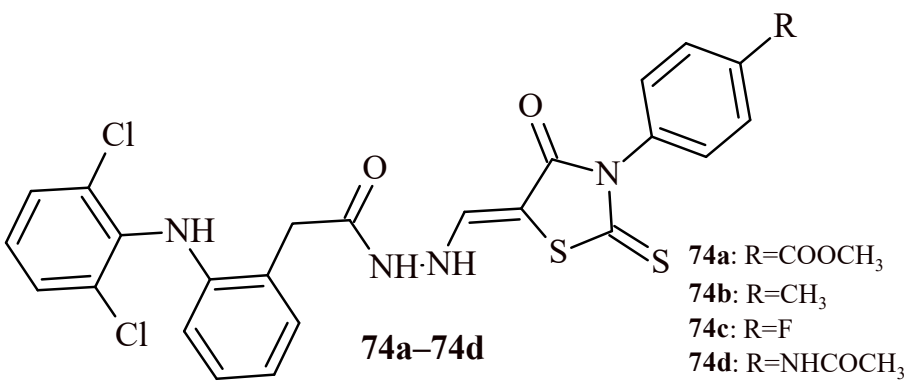

Figure 30. The rhodanine-diclofenac hybrids with anti-inflammatory activity.

\subsection{Anticonvulsant Activity}

Epilepsy is one of the most common brain diseases, affects over 70 million (1\%) people worldwide [69]. The available protocols for the treatment of epilepsy are very often imperfect, therefore the research of new anticonvulsants are real problems for medicinal chemistry. Mishchenko et al. conducted synthesis of darbufelone analogues (Les-6290, Les6291 and Les-6296) and evaluated their anticonvulsant effects in scPTZ test (Figure 31) [70]. As a reference drugs, darbufelone methansulfonate, celecoxib, sodium valproate and phenytoin was used in these experiments. Darbufelone methanosulfonate is a COX-2/5LOX dual inhibitor with anti-inflammatory activity used in the treatment of rheumatoid arthritis [71,72]. All the obtained derivatives showed a good pharmacological effect in terms of anticonvulsant activity. The action included a reduction of the number of seizures, a decrease in clonic and tonic seizures, and a protective effect against mortality, which was conducive to the full survival of the tested animals.

Administration of derivative Les-6291 $(100 \mathrm{mg} / \mathrm{kg})$ resulted in a 2.29-fold reduction in the number of seizures per one animal. The duration of the convulsive period was shortened in comparison with the control groups. It is worth adding, that the mortality of animals decreased to $52.38 \%$. After administration of Les-6291 at $53 \mathrm{mg} / \mathrm{kg}$, the number of clonic and tonic seizures were reduced by 50\%, 52.38\%, respectively. Additionally, the severity of seizures was reduced by 2.23 -fold. The compound Les-6291 showed anticonvulsant activity at both doses: $100 \mathrm{mg} / \mathrm{kg}$ and $53 \mathrm{mg} / \mathrm{kg}$. The number of animals with clonic seizures was reduced by $100 \%$ at a dose of $100 \mathrm{mg} / \mathrm{kg}$ and $50 \%$ at a dose $53 \mathrm{mg} / \mathrm{kg}$. The 
duration of the seizure period was also shortened to $0.10 \pm 0.00 \mathrm{~min}$ (at a dose $100 \mathrm{mg} / \mathrm{kg}$ ) and to $7.08 \pm 3.80 \mathrm{~min}$ (at a dose $53 \mathrm{mg} / \mathrm{kg}$ ).

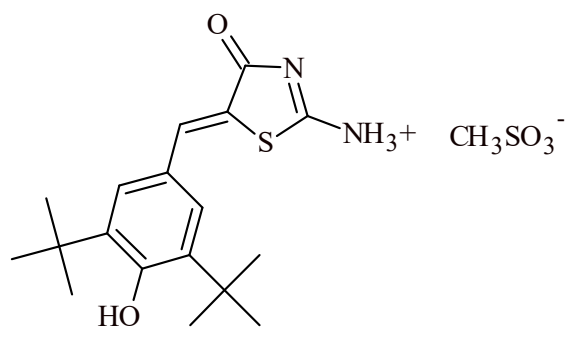

Darbufelone

COX-2/5-LOX dual inhibitor

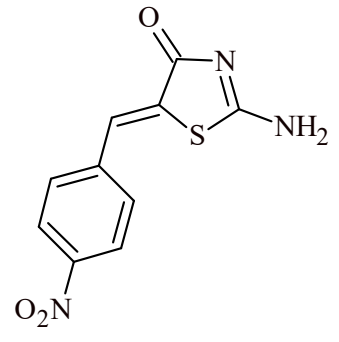

Les-6291

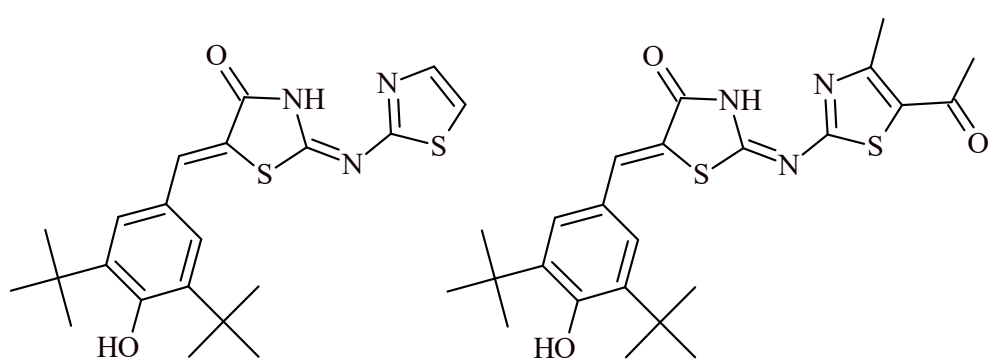

Les-6296

Les-6290

Figure 31. Darbufelone and its analogues with anticonvulsant activity.

The use of the Les-6290 derivative led to significant reduction of the number of clonic seizures by $16.67 \%$, as well as reduction in tonic seizures by $50 \%$ compared to darbufelone. The severity of seizures statistically decreased 1.52-fold and the mortality rate decreased to $69.04 \%$ compared to the control group. The compound Les-6296 was found to be the most potent in the experiment and showed high anticonvulsant activity at both doses: $100 \mathrm{mg} / \mathrm{kg}$ and $75 \mathrm{mg} / \mathrm{kg}$. The use of Les-6296 at a dose of $100 \mathrm{mg} / \mathrm{kg}$ led to a reduction of the number of tonic seizures. It is worth adding, that the administration of a dose of $75 \mathrm{mg} / \mathrm{kg}$ reduced the percentage of animals with both tonic (at 69.04\%) and clonic (at $16.67 \%$ ) seizures compared to the control group. In addition, the compound Les-6296, administered at both doses, was responsible for the absolute protective effect against death in the test animals compared to the group of treated with darbufelone.

It is worth noticing, that the presence of the thiazol-2-ylamine substituent in the Position 2 and the 3,5-ditertbutyl-4-hydroxybenzylidene at Position 5 of thiazolidin-4-one cycle are optimal for anticonvulsant activity. These conclusions are based on SAR analysis. In addition, it is worth emphasising, that the best pharmacological effect was obtained for compound Les-6296, which simultaneously became the lead compound. The synthesized derivatives showed a significant level of animals' protection, and they can be the future-proof compounds for the design of anticonvulsants with optimal pharmacokinetic parameters.

\subsection{Antidiabetic Activity}

Recent scientific research confirms the special role of protein tyrosine phosphatase $1 \mathrm{~B}$ (PTP1B) inhibitors as potential new antidiabetic drugs [73,74]. The mechanism of action of protein tyrosine phosphatase depends on dephosphorylation of tyrosine residues, which leads to inactivation of proteins responsible for insulin receptor stimulation [75]. As the consequence of said action, PTP1B leads to inactivation of insulin, so it has been suggested that this enzyme is crucial in the development of insulin resistance [76-81].

In the published in 2020 study, a number of derivatives with potential antidiabetic activity were synthesized (75a-75e, 76a-76e and 77a-77e) (Figure 32) [82]. These compounds were tested for their inhibitory activity against PTP1B in vitro using the Calbiochem PTP1B 
colorimetric kit. Suramin was used as a standard. The inhibitory potency was investigated by measuring the effect of each compound on phosphate production, the results of the inhibition assay are expressed as $\mathrm{IC}_{50}$. Generally, the resulting derivatives showed moderate to good inhibition of PTP1B. Their $\mathrm{IC}_{50}$ values ranged from $5.88 \mu \mathrm{M}(76 \mathrm{e})$ to $29.78 \mu \mathrm{M}(77 \mathrm{a})$. For comparison, the result of suramin (the reference substance) was $10.98 \mu \mathrm{M}$.<smiles>[R]c1ccc(/N=C2\NC(=O)/C(=C/c3cccs3)S2)cc1</smiles><smiles>[R]c1ccc(/N=C2\NC(=O)/C(=C/c3ccco3)S2)cc1</smiles>

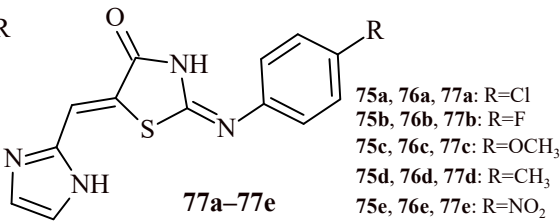

Figure 32. The 5-Heterylmethylidenethiazolidin-4-ones with PTP1B inhibitory activity.

Based on SAR analysis, there is the conclusion that presence of furan ring at Position 5 of thiazolidin-4-one ring is more preferable than two other heterocycles (thiophen and imidazole) for PTP1B inhibitory activity. The compounds (75e, 76e and 77e) with nitro group in para position of phenylamine moiety were most active and showed PTP1B inhibitory activity better than reference drug suramin with $\mathrm{IC}_{50}$ values $6.42,5.88$ and $7.93 \mu \mathrm{M}$, respectively. The moderate inhibitory effect was exhibited by derivatives $(\mathbf{7 5 c}, \mathbf{7 5 d}, \mathbf{7 6 c}$, 76d, 77c and 77d) with methyl and methoxy groups in phenylamine moiety. The presence of the electron-withdrawing groups $(\mathrm{Cl}, \mathrm{F})$, except Compound 76a, reduced the activity. The same trends were observed in computational results. The SAR of compounds (75a-77e) are illustrated in Figure 33.

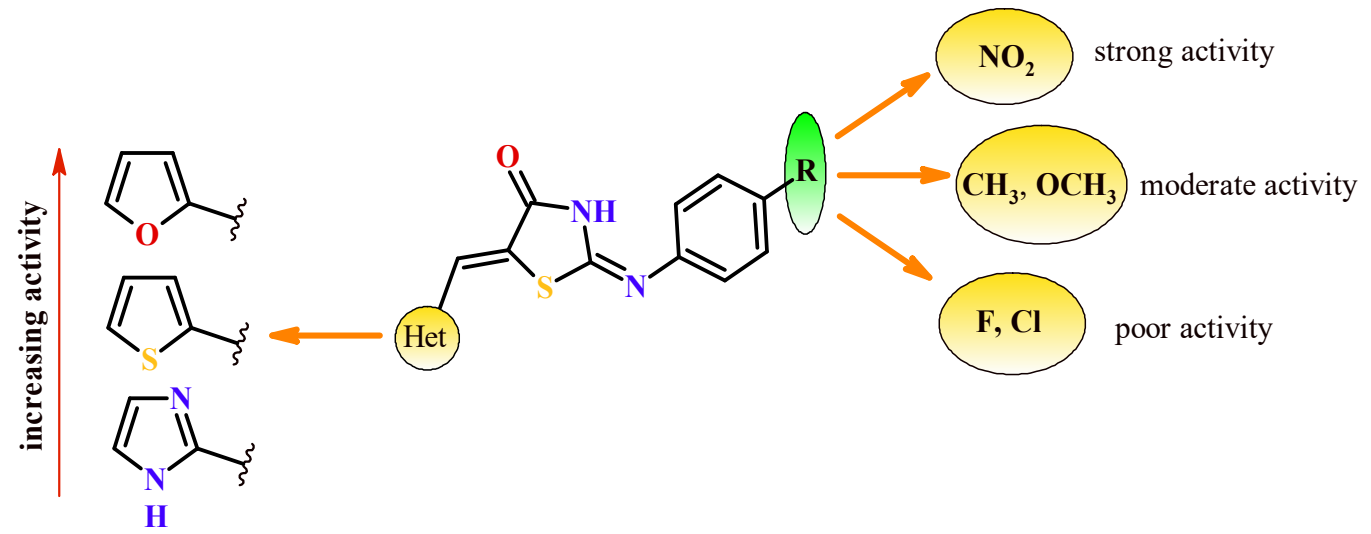

Figure 33. The SAR of different compounds (75a-77e).

Jiang et al. synthesized series of 5-(bromobenzylidene)thiazolidine-2,4-dione derivatives and their saturated analogues [83]. The activity of the synthesized derivatives was tested in vitro against recombinant human PTP1B (at a concentration of $20 \mu \mathrm{g} / \mathrm{mL}$ ). Initially, the percent of inhibition for all compounds involved in the experiment was measured. Subsequently, their $\mathrm{IC}_{50}$ values were determined for best-performing derivatives (>50\% inhibition).

The Derivatives 78 and $\mathbf{7 9}$ showed moderate PTP1B inhibition activity with IC $_{50}$ values 8.34 and $10.5 \mu \mathrm{M}$, respectively (Figure 34). Introducing the additional 2,3-dibromo4,5-dimethoxybenzyl group in the bromobenzylidene substituent of Compounds 78, 79 led to obtaining compounds $(\mathbf{8 0}, \mathbf{8 1}$ and $\mathbf{8 3})$ with high inhibitory activity against PTP1B with $\mathrm{IC}_{50}$ values $0.86,1.84$ and $2.10 \mu \mathrm{M}$, respectively. The exception was Compound 82 $\left(\mathrm{IC}_{50}=12.77 \mu \mathrm{M}\right)$ that showed moderate effect. The most potent inhibitor PTP1B, Compound 80, was found to be high selectivity against other PTPs. It is also worth adding, that Compound $\mathbf{8 0}$ was proven to be effective in reducing glucose, triglyceride and LDL-C levels in the BKS- $\mathrm{db} / \mathrm{db}$ mouse model at $50 \mathrm{mg} / \mathrm{kg}$. 


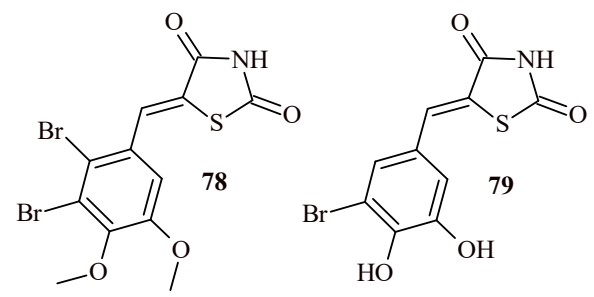<smiles>COc1cc(Cc2c(Br)cc(Br)c(OC)c2OC)c(/C=C2\SC(=O)NC2=O)cc1Br</smiles>

80<smiles>COc1cc(Cc2c(COc3ccc(CC4SC(=O)NC4=O)cc3)cc(Br)c(OC)c2OC)c(Br)c(Br)c1OC</smiles><smiles>COc1cc(Cc2c(Br)c(Br)c(OC)c(OC)c2OC)c(CC2SC(=O)NC2=O)cc1Br</smiles>

81<smiles>COc1cc(Cc2c(COc3ccc(/C=C4\SC(=O)NC4=O)cc3)cc(Br)c(OC)c2OC)c(Br)c(Br)c1OC</smiles>

Figure 34. The 5-(Bromobenzylidene)thiazolidine-2,4-dione derivatives (78-80 and 82) and their saturated analogues $(\mathbf{8 1}, \mathbf{8 3})$ as potential protein tyrosine phosphatase 1B inhibitor with antidiabetic properties.

Another way to treat diabetes leads to the activity of exocrine enzymes in pancreatic cells. In this case, treatment involves the inhibition of intestinal $\alpha$-glucosidase and amylase [84,85]. These enzymes are responsible for degradation of starch and oligosaccharides to monosaccharides such as glucose and fructose [85]. Inhibition of these enzymes plays a huge role in antidiabetic activity. Reduction of absorption of simple sugars into the bloodstream would contribute to a reduced fluctuation of sugar levels and would minimize the probability of postprandial hyperglycemia, and this effect is important in pharmacological treatment of diabetes [86]. In a recently published study, a number of thiazolidine-2,4-dione derivatives were synthesized and their influence on the inhibitory activity on the above-mentioned enzymes was investigated.

Fettach et al. synthesized series of 5-arylidenethiazolidine-2,4-diones (84a-84e) and their 3-allyl analogues (85a-85e) (Figure 35). The synthesized compounds were evaluated for their inhibitory activity towards $\alpha$-amylase and $\alpha$-glucosidase enzymes in vitro [87]. It has been shown that all tested derivatives had good or moderate activity toward $\alpha$ glucosidase $\left(\mathrm{IC}_{50}=43.85-380.10 \mu \mathrm{M}\right)$ in comparison with standard inhibitor (acarbose $\mathrm{IC}_{50}$ $=97.12 \mu \mathrm{M})$. The inhibitory effects of tested compounds against $\alpha$-amylase were in the range of $\mathrm{IC}_{50}=18.19-286.25 \mu \mathrm{M}$. Whereas, standard acarbose inhibited $\alpha$-amylase at $\mathrm{IC}_{50}$ value of $2.975 \mu \mathrm{M}$.<smiles>[R]c1ccc(/C=C2\SC(=O)NC2=O)cc1</smiles><smiles></smiles>

Figure 35. The 5-Arylidenethiazolidine-2,4-diones with $\alpha$-amylase and $\alpha$-glucosidase inhibitory activity. 
As the results of research, authors identified lead Compounds 84e, 85a and 85e that showed dual inhibitory effects of $\alpha$-amylase and $\alpha$-glucosidase enzymes. The lead Compounds 84e, 85a and 85e inhibited $\alpha$-amylase with $\mathrm{IC}_{50}: 47.09,108.14$ and $18.19 \mu \mathrm{M}$, respectively and $\alpha$-glucosidase with $\mathrm{IC}_{50}: 84.95,98.45$ and $43.85 \mu \mathrm{M}$, respectively. Additionally, the most potent compounds were non-toxic at concentration $2000 \mathrm{mg} / \mathrm{kg}$ b.w. in acute toxicity test on mice.

Toumi et al. $[88,89]$ carried out assay of series of rhodanine derivatives for their $\alpha$ amylase inhibitory activity. The first series rhodanine-based spirooxindole pyrrolidine derivatives (86a-86o and 87a-87d) (Figure 36) showed promising activities toward $\alpha-$ amylase enzyme. It is worth noticing that Compounds 86f, 86i and 860 ( $\mathrm{IC}_{50}$ values $1.49 \pm 0.10,1.50 \pm 0.07$ and $1.57 \pm 0.10 \mu \mathrm{M}$, respectively) followed by $86 \mathbf{j}, 87 \mathrm{c}$ and $87 \mathrm{~d}$ ( $\mathrm{IC}_{50}$ values $1.59 \pm 0.08,1.63 \pm 0.09$ and $1.67 \pm 0.09 \mu \mathrm{M}$, respectively) exhibited highest inhibitory activity [88]. These results were more potent or comparable to reference drug acarbose $\left(\mathrm{IC}_{50}=1.56 \pm 0.07 \mu \mathrm{M}\right)$. Other derivatives showed moderate inhibitory effects with $\mathrm{IC}_{50}$ values in the range of $1.72-3.06 \mu \mathrm{M}$. Moreover, authors carried out in vivo studies to evaluate influence of Compounds 86f, 86i, 86j and 860 on the blood glucose level in diabetic rats. The daily administration of Compounds $86 f, 86 \mathbf{8}, \mathbf{8 6 j}$ and 860 for one month to surviving diabetic rats showed significant decreasing of the serum glucose level by 6.8 , $12.3,5.5$ and $9.9 \%$, correspondingly in comparison with untreated diabetic rats.

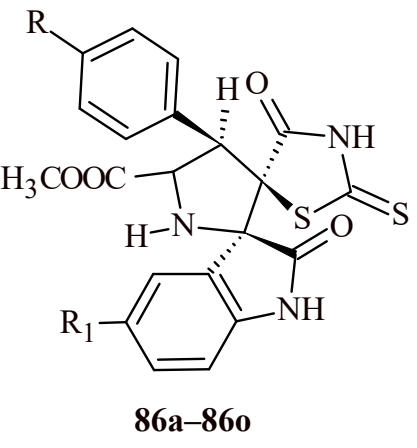

$86 a-860$

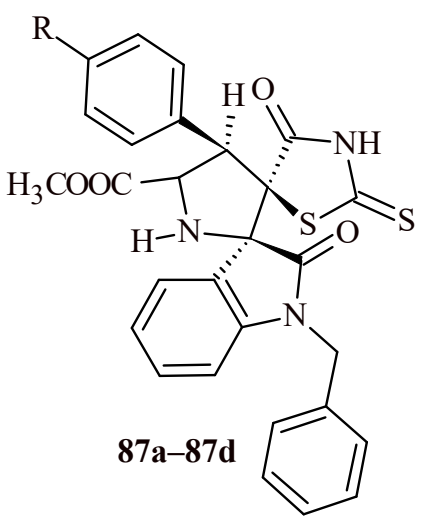

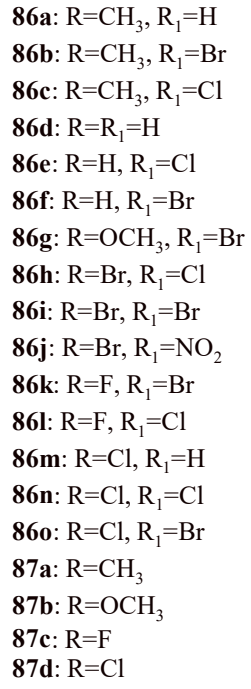

Figure 36. Three cyclic spiro rhodanine derivatives as $\alpha$-amylase inhibitor.

The second series of rhodanine-based tetrahydroisoquinoline derivatives (88a-88d) (Figure 37) exhibited less potential toward $\alpha$-amylase enzyme in comparison with series $1\left(\mathrm{IC}_{50}=5.98-18.06 \mu \mathrm{M}\right)$. The most active in vitro Compound $\mathbf{8 8 d} \mathrm{d}$ from Series 2 $\left(\mathrm{IC}_{50}=5.98 \mu \mathrm{M}\right)$ was tested with alloxan-induced diabetic rats on intestinal $\alpha$-amylase activity and the blood glucose level. The administration of Compound $88 \mathrm{~d}$ at dose of $30 \mathrm{mg} / \mathrm{kg}$ daily for 21 days significantly reduced the intestinal $\alpha$-amylase activity by $21.3 \%$ in comparison with untreated diabetic rats, decreased the blood glucose level by $39 \%$ [89]. 


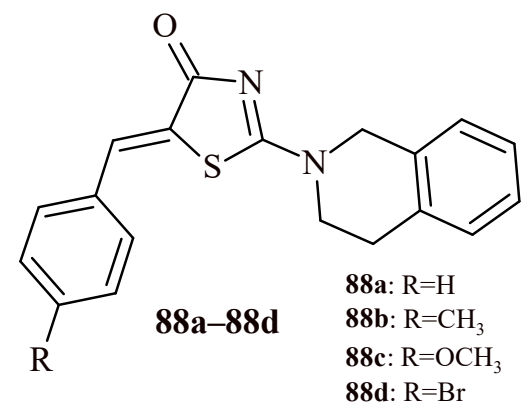

Figure 37. The structures of rhodanine-based tetrahydroisoquinoline derivatives.

Szabo et al. evaluated inhibitory activity of rhodanine derivatives (89a-89f and 90 ) towards porcine pancreatic $\alpha$-amylase (PPA) and $\alpha$-glucosidase (Figure 38). These rhodanine derivatives previously were reported as inhibitors of human aldose reductase (AR) and PTP1B [90]. Each of the tested compounds (89a-89f and 90) showed inhibitory potential against human $\mathrm{AR}$ at submicromolar/nanomolar concentration $\left(\mathrm{IC}_{50}=0.052-0.228 \mu \mathrm{M}\right)$. On the other hand, only Compounds $89 \mathrm{e}, 89 \mathrm{f}$ and 90 showed considerable inhibitory effects towards human PTP1B at concentration $<100 \mu \mathrm{M}$. The Compounds $89 \mathrm{a}-89 \mathrm{f}$ and 90 possessed diverse inhibitory potential in the tests towards $\alpha$-amylase and $\alpha$-glucosidase. Some of them exhibited appreciable effects at concentration $\leq 100 \mu \mathrm{M}$ (Compounds 89b-89d), others moderate or insignificant activities (Compounds 89a, 89e, 89f and 90). As further step of the study, it was evaluated whether inhibitory effects of Compounds 89a-89f and 90 might be due to specific interactions with multiple targets or to non-specific inhibition based on aggregation. Among the tested rhodanines Compounds 89b, 89e, 89f and 90 showed aggregation-based mechanism of action. Whereas Derivatives $89 a, 89 c, 89 d$ act as multi-target inhibitors without aggregates formation [91].<smiles>[R]c1ccc(/C=C2\SC(=S)N(CC(=O)O)C2=O)cc1</smiles><smiles>O=C1NC(=S)S/C1=C\c1ccc(Oc2ccccc2)cc1</smiles>

89a: $\mathrm{R}=3-\mathrm{OCH}_{2} \mathrm{CONH}_{2}$ 89b: $\mathrm{R}=4-\mathrm{OCH}_{2} \mathrm{CONH}_{2}$ 89c: $\mathrm{R}=3-\mathrm{OCH}_{3}, 4-\mathrm{OCH}_{2} \mathrm{CONH}_{2}$ 89d: $\mathrm{R}=4-\mathrm{OCH}_{3}, 3-\mathrm{OCH}_{2} \mathrm{CONH}_{2}$ 89e: $\mathrm{R}=4-\mathrm{OCH}_{2} \mathrm{C}_{6} \mathrm{H}_{5}$ 89f: $\mathrm{R}=3-\mathrm{OCH}_{2} \mathrm{C}_{6} \mathrm{H}_{5}$

Figure 38. The rhodanine derivatives as $\alpha$-amylase and $\alpha$-glucosidase inhibitor.

The series of oxazinyl-thiazolidin-4-ones (9a-9f), in addition to their antioxidant activity (Figure 4 ), showed inhibitory activity towards $\alpha$-amylase and $\alpha$-glucosidase enzymes in the range of $\mathrm{IC}_{50}$ values of $4.08-53.68 \mu \mathrm{g} / \mathrm{mL}$ and $1.01-39.12 \mu \mathrm{g} / \mathrm{mL}$, respectively [22]. The Compounds $9 \mathbf{a}$ and $\mathbf{9 b}$ revealed inhibition of $\alpha$-amylase at concentration 9.31 and $4.08 \mu \mathrm{g} / \mathrm{mL}$. These activities were better than activity of reference drug acarbose $\left(\mathrm{IC}_{50}=11.56 \mu \mathrm{g} / \mathrm{mL}\right)$. Additionally, these compounds (9a and $\left.\mathbf{9 b}\right)$, as well as Compound 9e, showed inhibitory effects against $\alpha$-glucosidase enzyme with IC $_{50}$ values of $1.01,6.14$ and $9.24 \mu \mathrm{g} / \mathrm{mL}$, respectively. These values also were more beneficial in comparison to acarbose $\left(\mathrm{IC}_{50}=17.23 \mu \mathrm{g} / \mathrm{mL}\right)$.

Bilgicli et al. reported, that the piperonyl-based thiazolidine-4-one derivative, namely: 3-(benzo[d] [1,3]dioxol-5-ylmethyl)-2-(4-nitrophenyl)thiazolidine-4-one, showed very potent inhibition of $\alpha$-glucosidase at nanomolar concentration $\left(\mathrm{IC}_{50}=5.9 \mathrm{nM}\right)$ (Figure 39) [92]. 
<smiles>O=C1CSC(c2ccc([N+](=O)[O-])cc2)N1Cc1ccc2c(c1)OCO2</smiles>

Figure 39. The structure of 3-(benzo[d][1,3]dioxol-5-ylmethyl)-2-(4-nitrophenyl)thiazolidine-4-one.

\subsection{Antiparasitic Activity}

Leishmaniasis is a mosquito-borne tropical disease, that is directly caused by protozoa of the genus Leishmania spp. The infection may take different forms. There are three basic forms of the disease: cutaneous, visceral and mucous $[93,94]$. Traditionally used drugs face problems such as toxicity, which leads to many side effects, and parasitic resistance $[95,96]$. Therefore, the need for the synthesis of new compounds that inhibit the parasitic pathways of the Leishmania genus is emphasized.

Bhat et al. conducted synthesis of quinoline-thiazolidin-4-one hybrids (91a-91f and 92-94) (Figure 40) and carried out their inhibitory activity towards LdMetAP1 and $H s$ MetAP1 in vitro [97]. Tested hybrids inhibited $L d$ MetAP1 with $\mathrm{IC}_{50}$ values in the range of 3.0-123.4 $\mu \mathrm{M}$ and HsMetAP1-54.2->200 $\mu \mathrm{M}$. Among the series of quinoline-thiazolidin4 -one hybrids, the best profile was characterized by a derivative with indole moiety (94). The Compound $94\left(\mathrm{IC}_{50}=3 \mu \mathrm{M}\right)$ showed high selectivity towards LdMetAP1 and 20 -fold less effectiveness for HsMetAP1 $\left(\mathrm{IC}_{50}=58 \mu \mathrm{M}\right)$. It was also found that Compound 94 demonstrated low cytotoxicity in the MTT test using mouse embryonic fibroblast cells $\left(\mathrm{IC}_{50}>150 \mu \mathrm{M}\right)$. Moreover, good pharmacokinetics features and good absorption of the drug after oral administration can be predicted because of calculated the $\log \mathrm{P}$ and LogS values.

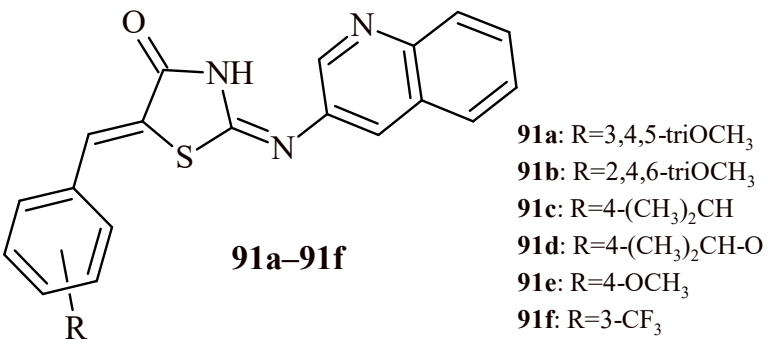<smiles>O=C1N/C(=N\c2cnc3ccccc3c2)S/C1=C/c1cc[nH]c1</smiles><smiles>O=C1N/C(=N\c2cnc3ccccc3c2)S/C1=C\c1ccsc1</smiles><smiles>O=C1N/C(=N\c2cnc3ccccc3c2)S/C1=C\c1cccc2cc[nH]c12</smiles>

Figure 40. The quinoline-thiazolidin-4-one hybrids as inhibitor of methionine aminopeptidase 1 from Leishmania donovani.

Another important feature of the new derivative is specificity for iron dependent MetAP. MetAP enzymes show high catalytic activity on divalent metals, and they usually show specificity for a specific metal cofactor [98-100]. Designing molecules of high sequestration properties of metals can play a significant role towards discovery of new 
inhibitors. The most important is a high potency drug to the biologically relevant form of the enzyme that is activated by metal. Inhibitors targeting MetAP1, which eliminate Leishmania spp. parasites, have the potential to become prime anti-leishmanial drugs. The new inhibitors have the potential to bypass the drug resistance, which is currently experienced in treatment using traditional drugs against leishmaniasis. Discovery of drugs similar to a synthesized derivative, which shows selectivity to $L d$ MetAP1, may help with development of new chemotherapeutic molecules.

Schadich et al. carried out the evaluation of 29 compounds belong with different thiazolidine-based hybrids against Leishmania major FV1 strain. Some of the tested compounds showed antitrypanosomal activity against Trypanosoma brucei and Trypanosoma gambiense [101]. The most effective was group of thiazolidin-4-one-indole hybrids (95a-95d) (Figure 41). The Compounds 95a-95d showed good antileishmanial activity against $L$. major in the range of $\mathrm{IC}_{50}$ values of 1.01-3.51 $\mu \mathrm{M}$, that was better than reference drug miltesofine $\left(\mathrm{IC}_{50}=8.18 \mu \mathrm{M}\right)$. The Hybrids 95a-95d also revealed good antitrypanosomal activity against $T$. gambiense $\left(\mathrm{IC}_{50}=0.11-0.23 \mu \mathrm{M}\right)$. Additionally, Compounds $95 \mathrm{c}$ and $95 \mathrm{~d}$ exhibited strong activity against $T$. brucei with $\mathrm{IC}_{50} 0.03$ and $0.06 \mu \mathrm{M}$, respectively. The most active compounds-95a-95c showed low cytotoxicity to normal human fibroblasts $\left(\mathrm{IC}_{50}>50 \mu \mathrm{M}\right)$ and good therapeutic index ( $\left.>29\right)$. Based on SAR analysis, it can be said, that the advantageous for antileeishmanial and antitrypanosomal activities is the unsubstituted Position 3 in the thiazolidine ring and the lack of a bulky substituent in the five positions of this ring.<smiles>[R]C1S/C(=N\N=C\c2c(-c3ccccc3)[nH]c3ccccc23)NC1=O</smiles>

95a: $\mathrm{R}=\mathrm{H}$, 95b: $\mathrm{R}=\mathrm{CH}_{3}$, 95c: $\mathrm{R}=\mathrm{C}_{2} \mathrm{H}_{5}, 95 \mathrm{~d}: \mathrm{R}=\mathrm{CH}_{3} \mathrm{COO}\left(\mathrm{CH}_{2}\right)_{2}$

Figure 41. Thiazolidin-4-one-indole hybrids with antitrypanosomal and antileishmanial activities.

Another method of inhibiting of the development of Leishmania spp. parasites is the inhibition of the biochemical pathway of the formation of folates. The Leishmania spp parasites receive tetrahydrofolate by action of the enzyme dihydrofolate reductasethymidylate synthetase. No effective drugs that act on this subunit such as methotrexate follow directly from the presence of pteridine reductase (PTR1) [102]. The conducted tests showed unequivocally, that PTR1 is an enzyme necessary for the growth and development of Leishmania spp. parasites [103]. Moreover, the selective inhibition of PTR1 is sufficient to inhibit the growth of the parasite, and the new drugs against leishmaniasis based on blocking this enzyme can be very effective $[104,105]$.

A series of thiazolidine-2,4-dione derivatives (96a-96g) with antileishmanial activity was synthesized by Neri et al. (Figure 42) [106]. Their activity is based on the above presented mechanism. The Compounds $\mathbf{9 6 a - 9 6 g}$ showed antileishmanial activity at $\mathrm{EC}_{50}$ concentration range of 44.16-70.98 $\mu \mathrm{M}$ (for Leishmania braziliensis) and 23.45-68.77 $\mu \mathrm{M}$ (for Leishmania infantum). The most effective compounds against $L$. infantum $(\mathbf{9 6 b}, \mathbf{9 6 \mathbf { d }}$ and $\mathbf{9 6 f}$, $\mathrm{EC}_{50}=23.45,35.90$ and $30.36 \mu \mathrm{M}$, respectively) had halogen substituent in Positions 3, 4 or 5 of phenyl group. The introduction of halogen in Positions 2 or 6 led to decreased activity. The main insufficiency of these compounds is their cytotoxicity. Tested compounds showed $\mathrm{LD}_{50}$ values in the range of 26.67-61.29 $\mu \mathrm{M}$ against WI-26VA4 cell line, except Compound 96c $\left(\mathrm{LD}_{50}>100 \mu \mathrm{M}\right)$. Only two compounds (96b and $\left.96 \mathbf{c}\right)$ exhibited a selectivity index more than one. 


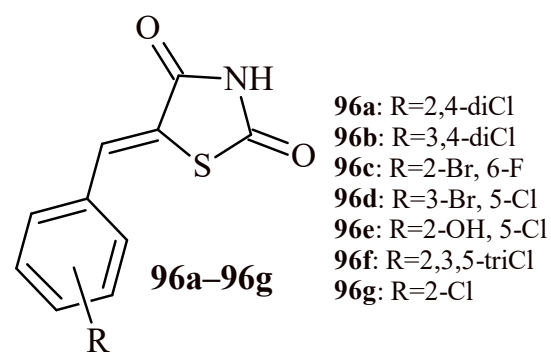

Figure 42. The 5-(Halogenbenzylidene)thiazolidine-2,4-dione derivatives with antileishmanial activity.

The inhibition constant $(\mathrm{Kd})$ of $L m$ PTR1 was determined by ThermoFluor ${ }^{\circledR}$ assays. According to this method, Compound 96f $(\mathrm{Kd}=18.56 \mu \mathrm{M})$ has the lowest $\mathrm{Kd}$ value, followed by Compound 96b $(23.12 \mu \mathrm{M}), \mathbf{9 6 d}(25.35 \mu \mathrm{M}), \mathbf{9 6 e}(89.98 \mu \mathrm{M})$, and 96g $(98.11 \mu \mathrm{M})$. Compound $96 \mathrm{f}$ seems to have higher affinity to LmPTR1 than previous lead compound (96d). The conducted analyzes show, that the presence of small lipophilic substituents at the meta and/or para positions are necessary for the efficacy of the compounds against LmPTR1. Ortho positioned lipophilic substituents affect the biological activity of the compound against L. infantum. Moreover, the derivative having in its structure chlorine atoms in Positions 3 and 4 in phenyl group (compound 96b) was characterized by the best profile of activity from the group of synthesized compounds with the greatest activity. It was considered the most interesting derivative due to its enzymatic and cellular properties.

It is also worth emphasizing the importance of the 2-ylidenehydrazinylidenethiazolidin4-one moiety for antiparasitic activity (violet color in Figure 43). The (4-oxothiazolidin5-yl)acetic acid Derivatives 97a and 97b showed good antitrypanosomal activity against trypomastigote form with $\mathrm{EC}_{50}$ values of 8.45 and $29.26 \mu \mathrm{M}$, respectively. These values were better than those for standard benzimidazole $\left(\mathrm{EC}_{50}=34.5 \mu \mathrm{M}\right)$. Furthermore, the Compounds $97 \mathbf{a}$ and $\mathbf{9 7 b}$ demonstrated better $\mathrm{IC}_{50}$ values for both Leishmania amazonensis $\left(\mathrm{IC}_{50}=14.63\right.$ and $\left.13.35 \mu \mathrm{M}\right)$ and Leishmania infantum $\left(\mathrm{IC}_{50}=14.63\right.$ and $\left.13.35 \mu \mathrm{M}\right)$ in comparison with reference drug miltefosine (36.31 and $53.71 \mu \mathrm{M})$ [107].<smiles>[R]c1ccc(/C=N\NC2=NC(=O)C(CC(=O)OCC)S2)cc1</smiles>

antitrypanosomal and antileishmanial activity

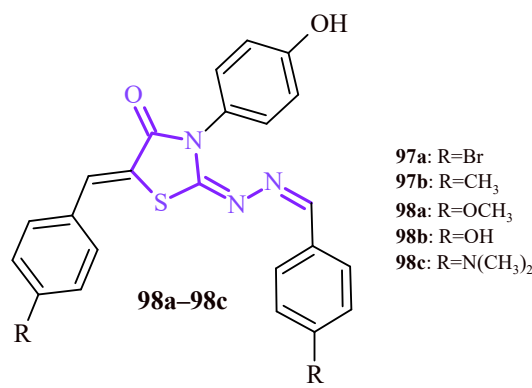

antimalarial activity<smiles>COC(=O)/C=C1\S/C(=N/N=C(C)\C(C)=N\O)NC1=O</smiles><smiles>COC(=O)/C=C1\S/C(=N/N=C(/C)c2ccccn2)NC1=O</smiles><smiles>COC(=O)/C=C1\S/C(=N/N=C\c2ccccc2O)NC1=O</smiles>

anti-Toxoplasma gondii activity

Figure 43. The 2-ylidenehydrazinylidenethiazolidin-4-one derivatives with antiparasitic activities. 
Kryshchyshyn et al. reported that 5-arylidene-3-(4-hydroxyphenyl)thiazolidin-4-ones (98a-98c) showed antimalarial activity against Plasmodium falciparum. The $\mathrm{IC}_{50}$ values were in the range of 2.32-3.50 $\mu \mathrm{M}$ [108].

Another study concerns to anti-T. gondii activity. The group of (4-oxothiazolidin-5ylidene)acetic acid derivatives (99-101) showed activity against $T$. gondii with $\mathrm{IC}_{50}$ values of $0.46,0.20$ and $0.66 \mu \mathrm{M}$, respectively. In addition, besides the anti-T. gondii activity, Compounds 99-101 had also lower toxicity towards the host cells $\left(\mathrm{TD}_{50}=60,206,125 \mu \mathrm{M}\right.$, correspondingly) [109].

The rhodanine-3-carboxylic acid Derivative 102 (Figure 44) exhibited also antitrypanosomal effects against T. brucei brucei and T. brucei gambiense at half maximal inhibitory concentration 19.19 and $5.03 \mu \mathrm{M}$. Moreover, Compound 102 showed low cytotoxicity towards fibroblast cells $\left(\mathrm{CC}_{50}=182.41 \mu \mathrm{M}\right)$ and good selectivity $(\mathrm{SI}=9.5$ and 36.2 , respectively) [110].<smiles>CCOC(=O)CCN1C(=O)/C(=C/Nc2cccnc2)SC1=S</smiles>

Figure 44. The structure of ethyl 3-[4-oxo-5-[(3-pyridylamino)methylene]-2-thioxothiazolidin-3yl]propanoate (102).

The good antitrypanosomal activity against $T$. brucei brucei showed two thiazolidin-4-onediclofenac hybrids, namely: [2-(2,6-dichlophenylamino)phenyl]acetic acid $\mathrm{N}$-(3-ethyl-4-oxo-2thioxothiazolidin-5-ylidenemethyl)hydrazide and [2-(2,6-dichlophenylamino)phenyl]acetic acid $\mathrm{N}$-(2,4-dioxothiazolidin-5-ylidenemethyl)hydrazide. Their $\mathrm{IC}_{50}$ values were 7.06 and $4.8 \mu \mathrm{M}$, correspondingly [68].

\subsection{Antimicrobial Activity}

Despite the wide number of groups of compounds used in microbial and fungal infections, diseases continue to grow in strength and their treatment is a serious problem of a medical nature. Widespread and extensive use of antibiotics contributed to the development of pathogen resistance resulted the need to synthesize new antimicrobial drugs with a mechanism of action bypassing antibiotic resistance. The emergence of multi-resistant pathogenic strains is the undoubted challenge of modern medicine, and the prevention of infectious diseases is a serious global problem [111,112].

Chaban et al. performed synthesis and antimicrobial screening of 4-oxothiazolidin2-ylidene derivatives [113]. In the first stage of antimicrobial screening, it was evaluated the growth inhibition (\%) of tested compounds against methicillin-resistant Staphylococcus aureus (ATCC 43300) (Gram-positive) and four Gram-negative strains: Escherichia coli (ATCC 25922), Klebsiella pneumoniae (ATCC 700603), Acinetobacter baumannii (ATCC 19606), and Pseudomonas aeruginosa (ATCC 27853) as well as two fungal strains: Candida albicans (ATCC 90028) and Cryptococcus neoformans var. Grubii (H99; ATCC 208821). The compounds (103a-103d, 104a, 104b, 105 and 106) (Figure 45) were selected for the next stage of antimicrobial screening and showed significant microbial growth inhibition. The minimal inhibitory concentration (MIC) measurements were performed. The ceftriaxone and amphotericin were used as reference drugs for antibacterial and antifungal activity, respectively. The Compounds 103b and 103c showed antibacterial activity (MIC $=4-32 \mu \mathrm{g} / \mathrm{mL}$ ) against all tested bacterial strains comparable to ceftriaxone. The highest antifungal effect was exhibited by Compounds 104a and 104b that inhibited growth of $C$. neoformans with MIC values 4 and $8 \mu \mathrm{g} / \mathrm{mL}$, respectively. Worth noticing, except 105 and $106\left(\mathrm{CC}_{50}=8\right.$ 
and $6.86 \mu \mathrm{g} / \mathrm{mL}$, respectively) that compounds (103a-103d, 104a and 104b) revealed low cytotoxicity against human embryonic kidney cells HEK-293 $\left(\mathrm{CC}_{50}>32 \mu \mathrm{g} / \mathrm{mL}\right)$. The Compounds $107 \mathrm{a}-107 \mathrm{~d}$ and 108 with unsubstituted amido group showed high antibacterial activity against $S$. aureus with growth inhibition in the range of 85.3-97.9\% [114].<smiles>[R]c1ccc(CC2S/C(=C(/C#N)C(=O)NCc3ccco3)N(c3ccccc3)C2=O)cc1</smiles><smiles>[R]OC(=O)/C=c1\s/c(=C(/C#N)C(=O)NCc2ccco2)n(-c2ccccc2)c1=O</smiles><smiles>N#C/C(C(=O)NCc1ccco1)=c1/s/c(=C\c2cccnc2)c(=O)n1-c1ccccc1</smiles>

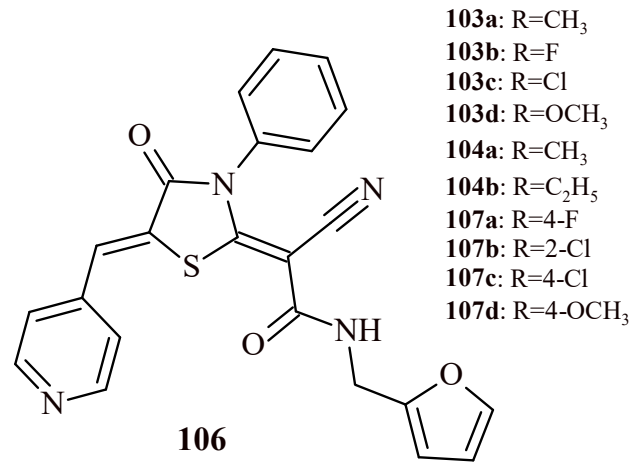<smiles>[R]c1ccc(CC2S/C(=C(/C#N)C(N)=O)N(c3ccccc3)C2=O)cc1</smiles><smiles>N#C/C(C(N)=O)=c1/s/c(=C\c2ccc(Cl)cc2)c(=O)n1-c1ccccc1</smiles>

Figure 45. The structures of 4-oxothiazolidin-2-ylidene derivatives with potential antimicrobial activity.

In the paper published by Kumar et al. [20], antimicrobial activity of 5-arylidenethiazolidine2,4-dione derivatives (5a-5s and $\mathbf{6}$ ) was discussed (Figure 2). Synthesized TZD derivatives were evaluated for their in vitro antimicrobial activity by serial tube dilution procedure. The antibacterial screening results were found to be comparable with cefadroxil, a standard drug used in bacterial infections and exceeded fluconazole in terms of antifungal activity. The screening revealed that Compounds $\mathbf{5 l}$ and $\mathbf{5 d}$ were moderately active against $S$. aureus (MIC of $17.9 \mu \mathrm{M}$ and $18.2 \mu \mathrm{M}$, respectively). Compounds $\mathbf{5 o}$ and $5 \mathbf{i}$ were moderately active against Bacillus subtilis (MIC of $18.5 \mu \mathrm{M}$ and $18.6 \mu \mathrm{M}$, respectively), Compounds $5 \mathbf{l}$ and $5 \mathrm{~h}$ were effective against $K$. pneumoniae (MIC $=17.9$ and $18.6 \mu \mathrm{M}$, respectively). Compound $5 \mathbf{n}(\mathrm{MIC}=18.5 \mu \mathrm{M})$ and Compound $5 \mathrm{~h}(\mathrm{MIC}=18.6 \mu \mathrm{M})$ exhibited promising activity against Salmonella typhi. The antifungal screening results revealed that the Compounds $5 \mathbf{l}(\mathrm{MIC}=17.9 \mu \mathrm{M})$ and $\mathbf{5 n}(\mathrm{MIC}=18.5 \mu \mathrm{M})$ had good activity against $C$. albicans and Aspergillus niger. The most active derivative against $C$. albicans was $5 \mathbf{k}(\mathrm{MIC}=16.1 \mu \mathrm{M})$. 
Firstly, substitution of electron-donating methyl group at ortho and para position in Compound $5 \mathrm{~h}$ increased the antibacterial potential against S. typhi and K. pneumoniae. Presence of an electron-withdrawing nitro group (51) in meta position enhanced antibacterial potential against $K$. pneumoniae and $S$. aureus as well as antifungal activity against $C$. albicans and $A$. niger. Furthermore, presence of electron-withdrawing fluorine substituent at ortho position of the synthesized Compound $5 \mathbf{j}$ enlarged the antibacterial potential against $E$. coli (Figure 46). No doubt, that thiazolidin-4-one derivatives are an appropriate base for the synthesis of subsequent derivatives with antimicrobial activity.

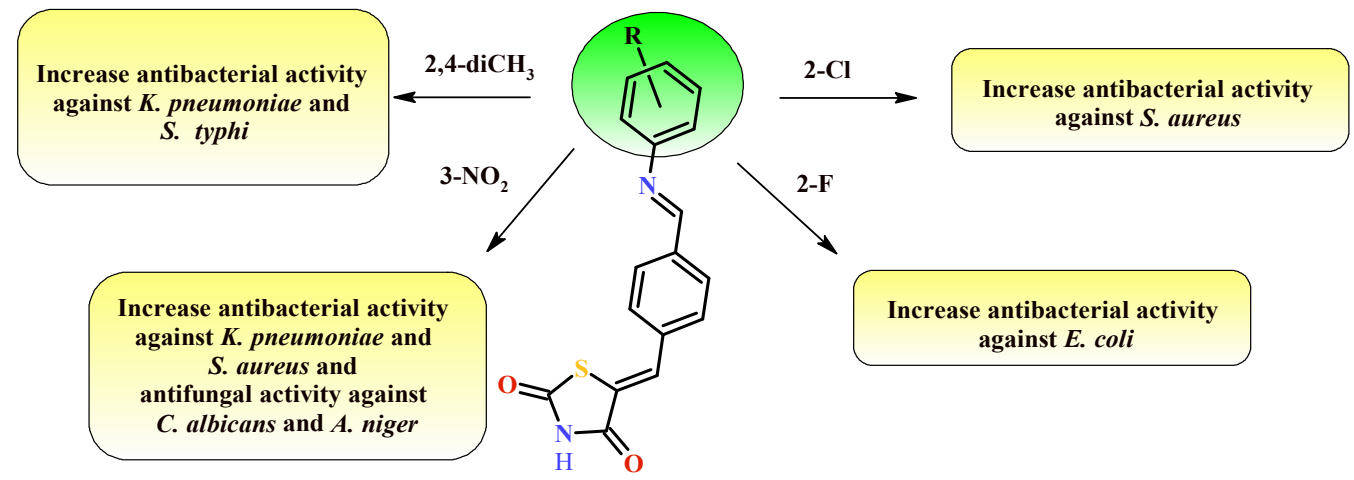

Figure 46. Influence of substituents on antimicrobial activity compounds (5a-5s).

It is worth to pay attention to Compound 109 (Figure 47) among the TZD derivatives, that exhibited good antibacterial as well as antifungal activity. The minimal inhibitory concentration against $S$. aureus and B. subtilis was $0.5 \mu \mathrm{g} / \mathrm{mL}$. This derivative was active against Gram-negative strain E. coli and P. aeruginosa at MIC $=1 \mu \mathrm{g} / \mathrm{mL}$. The Compound 109 showed antifungal activity also at Concentration $1 \mu \mathrm{g} / \mathrm{mL}$ against Aspergillus flavus, Trichoderma harzianum, Penicillium chrysogenum and C. albicans. Al these values were better than for reference drugs ciprofloxacin (MIC $=2 \mu \mathrm{g} / \mathrm{mL}$ ) and fluconazole (MIC $=2 \mu \mathrm{g} / \mathrm{mL}$ ) [115].
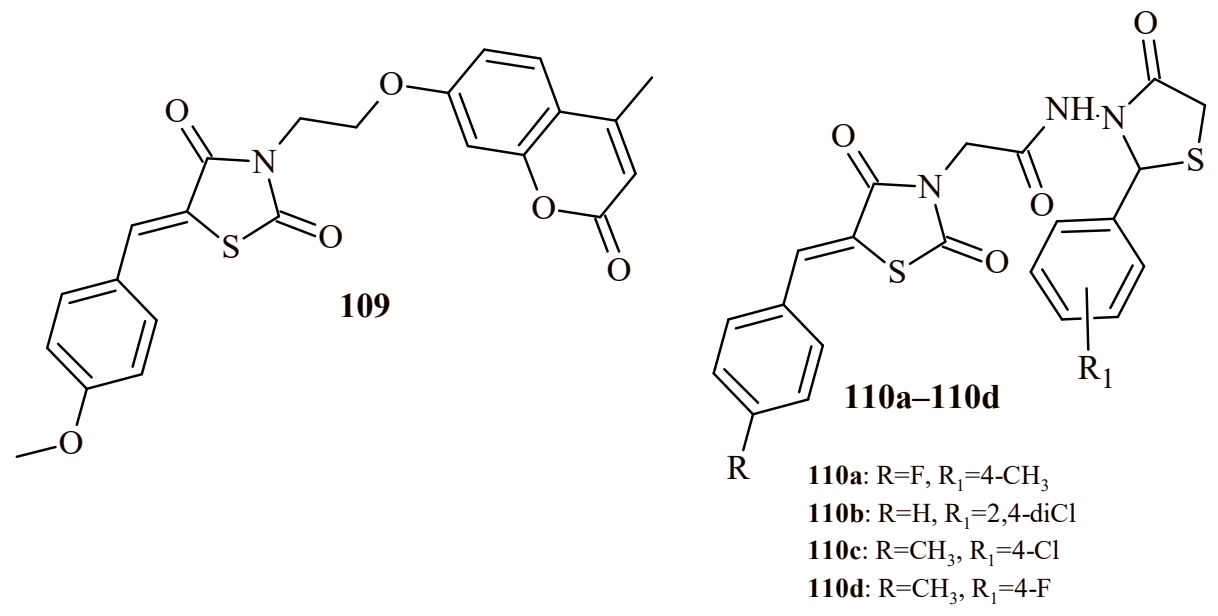

Figure 47. TZD derivatives with antimicrobial potential.

The group of Compounds 110a-110d showed antibacterial activity against Grampositive (S. aureus, Bacillus cereus, Micrococcus luteus) and Gram-negative (Pseudomonas fluorescens, E. coli, Flavobacterium devorans) strains with MIC values in the range of $2-4 \mu \mathrm{M}$. These results were comparable with reference drugs ampicillin, kanamycin and chloramphenicol [116].

Among the thiazolidin-4-ones (111a, 111b) with trifluoromethoxy group, Compound 111a showed antibacterial activity at minimal inhibitory concentration of $100 \mu \mathrm{g} / \mathrm{mL}$ against $S$. aureus and Listeria monocytogenes strains. Slightly better activity was exhibited by 
their chlorosubstituted analogues (111c, 111d) against L. monocytogenes and P. aeruginosa resistant strain with MIC $=60 \mu \mathrm{g} / \mathrm{mL}[117,118]$.

The replacement of benzothiazole moiety by the benzimidazole fragment (Compounds 112a-112l) led to increasing antibacterial activity both for Gram-positive and Gram-negative strains (Figure 48). The most active compound against S. aureus was Derivative $112 \mathrm{k}$ with trifluoromethyl substituent $(\mathrm{MBC}=0.12 \mu \mathrm{M})$. The compounds with trifluoromethyl and bromo groups (112d, 112e and $\mathbf{1 1 2}$ ) were most active against $K$. pneumoniae $(\mathrm{MBC}=0.14 \mu \mathrm{M})$. Whereas Compound 1121 showed activity against three Gram-negative strains (Salmonella thyphimurium, K. pneumonia and E. coli) with MBC value $0.15 \mu \mathrm{M}$ [119].<smiles>[R]c1ccc(C2SCC(=O)N2c2nc3ccc([As])cc3s2)cc1</smiles>

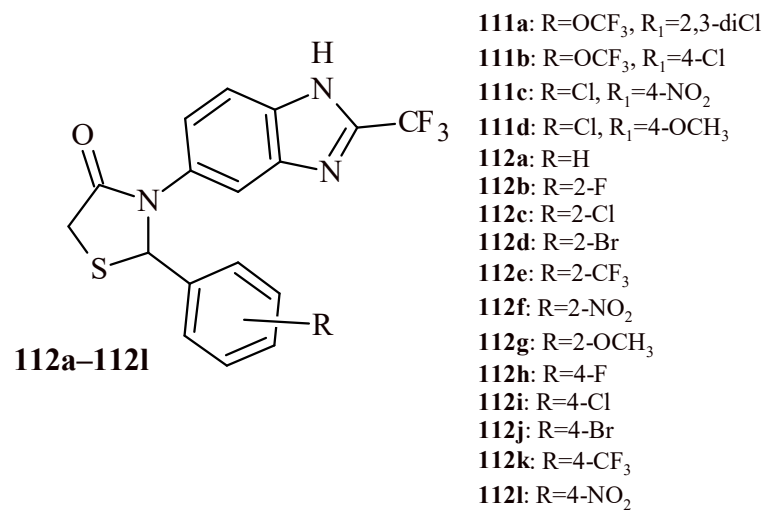

Figure 48. The structures of thiazolidin-4-ones with benzothiazole and benzimidazole moieties.

Zhang et al. reported antifungal activity of Compounds 113a-113d against $C$. albicans, Candida tropicalis, Aspergillus fumigatus and C. neoformans fungal strains with MIC in the range of $2-4 \mu \mathrm{g} / \mathrm{mL}$ [120]. Other derivative with quinoxaline moiety (114) showed comparable antibacterial and antifungal activity to reference drugs ampicillin (inhibition zone 23-28 mm) and amphotericin B (inhibition zone 14-20 mm) (Figure 49). The inhibition zone of 114 against $S$. aureus and E. coli were 24 and $19 \mathrm{~mm}$, respectively. The Compound 114 inhibited growth of A. flavus and C. albicans with inhibition zone $13 \mathrm{~mm}$ [121].<smiles></smiles>

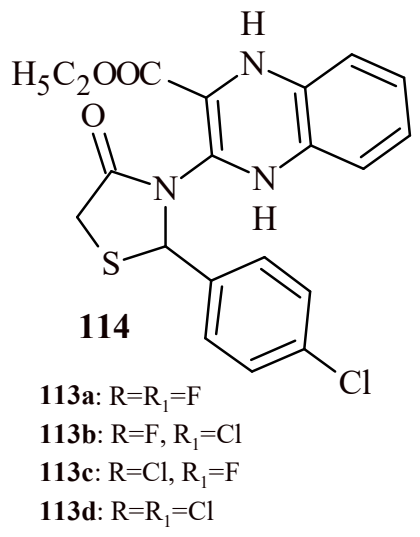

Figure 49. The structures of thiazolidin-4-ones with quinoxaline moiety.

The Compounds $\mathbf{1 1}$ and 43a (Figures 7 and 18) exhibited strong antimicrobial activity against four bacterial (E. coli, K. pneumoniae, S. aureus and B. subtilis) and three fungal (A. niger, Aspergillus oryzae and C. albicans) strains with MIC $=1.5 \mu \mathrm{g} / \mathrm{mL}$. This activity was comparable or slightly better than reference drugs streptomycin, ciprofloxacin and fluconazole [25,26].

Among the 3-amino-2-aryl/alkylthiazolidin-one derivatives, Compound 115 (Figure 50) showed higher inhibitory activity (inhibition zone $-8-17 \mathrm{~mm}$ ) than standard chloramphenicol (5-15 mm) to concentration $150 \mu \mathrm{g} / \mathrm{mL}$ against all tested strains (Proteus vulgaris, E. coli, K. 
pneumoniae, P. aeruginosa and S. aureus) [122]. Among the series of 116a-116d, Compound 116c with chloro substituent showed the antibacterial activity against E. coli practically equivalent to trimethoprim and better than trimethoprim against Acinetobacter baumannii and Streptococcus pyogenes [123]. The biphenylbased thiazolidine-4-ones (117a-117c) showed good antimicrobial against bacterial (E. coli, S. aureus, B. subtilis) and fungal (A. niger, C. albicans) strains, except 117c that exhibited moderate effect against fungal strains [124].<smiles>CC(C)(S)C1SCC(=O)N1NC(=O)COc1cc(=O)oc2ccccc12</smiles><smiles>[R]c1ccc(C2SCC(=O)N2NC(=O)CNc2ccc(CO)cc2)cc1</smiles><smiles>[R]c1ccc(C2SCC(=O)N2NC(=O)c2ccc(-c3ccccc3)cc2)cc1</smiles><smiles>[R]C1CCC2(CC1)SC(C)C(=O)N2NC(=O)c1[nH]c2ccc(S(N)(=O)=O)cc2c1-c1ccccc1</smiles><smiles>[R]c1ccc(C2SCC(=O)N2N=C(C)N2N=C(c3ccccc3)CC2c2ccccc2[N+](=O)[O-])cc1</smiles><smiles>[R]c1ccc(C2SCC(=O)N2Nc2ccc(S(N)(=O)=O)cc2)cc1</smiles>

116a: $R=\mathrm{OH} ; 116 b: R=\mathrm{OCH}_{3} ; 116 \mathbf{c}: \mathrm{R}=\mathrm{Cl} ; 116 \mathrm{~d}: \mathrm{R}=\mathrm{N}\left(\mathrm{CH}_{3}\right)_{2} ; 117 \mathrm{a}: \mathrm{R}=\mathrm{Cl} ; 117 \mathbf{b}: \mathrm{R}=\mathrm{Br} ; 117 \mathbf{c}: \mathrm{R}=\mathrm{NO}_{2} ; 118 \mathrm{a}: \mathrm{R}=3-\mathrm{CH}_{3} ; 118 b: \mathrm{R}=4-\mathrm{CH}_{3}$ 118c: $\mathrm{R}=4-\mathrm{C}_{2} \mathrm{H}_{5} ; 118 \mathrm{~d}: \mathrm{R}=4-\mathrm{C}_{3} \mathrm{H}_{7} ; 118 \mathrm{e}: \mathrm{R}=4-\mathrm{C}_{6} \mathrm{H}_{5} ; 119 \mathrm{a}: \mathrm{R}=2-\mathrm{NO}_{2} ; 119 \mathrm{~b}: \mathrm{R}=2-\mathrm{OH} ; 119 \mathrm{c}: \mathrm{R}=4-\mathrm{OH}, 3-\mathrm{OCH}_{3} ; 120 \mathrm{a}: \mathrm{R}=\mathrm{Cl} ; 120 \mathrm{~b}: \mathrm{R}=\mathrm{CH}_{3}$ 120c: $\mathrm{R}=\mathrm{OCH}_{3}$

Figure 50. The structures of 3-amino-2-aryl/alkylthiazolidin-ones with antimicrobial activity.

The spiro derivatives (118a-118e) showed good to moderate antibacterial activity against S. aureus ATCC 29213 MSSA and S. aureus ATCC 33951 MRSA strains. The Compounds $\mathbf{1 1 8 c}$ and $\mathbf{1 1 8 d}$ were most active against $S$. aureus MSSA strain at MIC $=9.765 \mu \mathrm{g} / \mathrm{mL}$. The Compound $\mathbf{1 1 8 b}$ inhibited growth of S. aureus MSSA, while Compound 118a was most active against $S$. aureus MRSA at concentration $19.53 \mu \mathrm{g} / \mathrm{mL}$. The moderate antibacterial effect showed Compounds $\mathbf{1 1 8 b}$ (S. aureus MRSA), 118e (S. aureus MSSA) with $\mathrm{MIC}=39.06 \mu \mathrm{g} / \mathrm{mL}$ and $\mathbf{1 1 8 c}, \mathbf{1 1 8 d}, \mathbf{1 1 8 e}$ (S. aureus MRSA) as well as 118a (S. aureus MSSA) at concentration $78.12 \mu \mathrm{g} / \mathrm{mL}$. The cyclopentane spiro derivatives, analogues of 118 were no active (MIC $>2500 \mu \mathrm{g} / \mathrm{mL}$ ) [125].

Among the thiazolidine-4-one derivatives with pyrazole moiety, the most active were Compounds 119a-119c, that showed antibacterial activity at MIC $=12.5 \mu \mathrm{g} / \mathrm{mL}$ against $B$. subtilis (119a), S. aureus (119c) and P. aeruginosa (119b) [126]. Unfortunately, none of the tested Compounds 120a-120c was active against bacterial and fungal strains at concentration less tha $50 \mu \mathrm{g} / \mathrm{mL}$ [127].

Hammad et al. carried out evaluation of 3-allylthiazolidin-4-ones for their antimicrobial potential. The Compounds 121a-121e with methyl and methoxy groups and 121f with para-nitro group (Figure 51) exhibited slight antibacterial activity against Gram-positive and Gram-negative bacterial strains with percent of growth inhibition 16-24\% at aconcentration of $32 \mu \mathrm{g} / \mathrm{mL}$. Additionally, Compound $121 \mathrm{f}$ inhibited S. aureus HG001 biofilm formation with percentages of $35 \%$ and $54 \%$ at a concentration of 32 and $64 \mu \mathrm{g} / \mathrm{mL}$, respectively. Unsubstituted compound in Position 5 of thiazolidine ring (122a) showed full growth of inhibition (100\%) against C. neoformans at concentration at $32 \mu \mathrm{g} / \mathrm{mL}$ [128]. 
<smiles>[R]c1ccc(/C=C2\S/C(=N\c3ccc(Cl)c(Cl)c3)N(CC=C)C2=O)cc1</smiles>

$121 \mathrm{a}-121 \mathrm{f}$<smiles>[R]N1C(=O)CS/C1=N\c1ccc(Cl)c(Cl)c1</smiles>

$122 a-122 d$<smiles>COc1cc(/C=C2\S/C(=N\c3ccc(Cl)c(Cl)c3)N(C3CCCCC3)C2=O)ccc1O</smiles>

123<smiles>[R]c1ccc(/C=C2\S/C(=N/c3ncc(C)s3)NC2=O)cc1</smiles>

124<smiles>O=C1/C(=C/c2cccs2)S/C(=N\c2ccc(Cl)c(Cl)c2)N1C1CCCCC1</smiles>

121a: $\mathrm{R}=4-\mathrm{CH}_{3} ; 121 \mathrm{~b}: \mathrm{R}=3-\mathrm{OCH}_{3} ; 121 \mathrm{c}: \mathrm{R}=4-\mathrm{OCH}_{3} ; 121 \mathrm{~d}: \mathrm{R}=2,4-\mathrm{diOCH}_{3} ; 121 \mathrm{e}: \mathrm{R}=3,4,5-$ triOCH$_{3} ; 121 \mathrm{f}: \mathrm{R}=4-\mathrm{NO}_{2}$ 122a: $\mathrm{CH}_{2} \mathrm{CH}=\mathrm{CH}_{2} ; 122 b: \mathrm{C}_{2} \mathrm{H}_{5} ; 122 \mathrm{c}: \mathrm{C}_{3} \mathrm{H}_{7} ; 122 \mathrm{c}$ : cyclo- $\mathrm{C}_{6} \mathrm{H}_{11} ; 125 \mathrm{a}: \mathrm{R}=\mathrm{H} ; \mathbf{1 2 5 b}: \mathrm{R}=4-\mathrm{OH} ; 125 \mathbf{c}: \mathrm{R}=4-\mathrm{OCH}_{3}$ 125d: $\mathrm{R}=2,5-\mathrm{diOCH}_{3}$; 125e: $\mathrm{R}=3-\mathrm{NO}_{2} ;$ 125f: $\mathrm{R}=3-\mathrm{F} ; 125 \mathrm{~g}: \mathrm{R}=4-\mathrm{Cl} ; \mathbf{1 2 5 h}: \mathrm{R}=2,4-d i C l ; 125 \mathrm{i}: \mathrm{R}=2,6-d i C l ; 125 \mathrm{j}: \mathrm{R}=3-\mathrm{Br}$

Figure 51. The structures of 2-iminothiazolidin-4-one derivatives.

Continuing their research, Hammad et al. carried out the evaluation of other 3alkylthiazolidin-4-ones (122a-122d, 123 and 124) for their antibacterial activity. Among the unsubstituted derivatives in Position 5 (122a-122d), three compounds (122a-122c) showed antibacterial effect against E. coli JW55031 (tolC Mutant) at concentration at $16 \mu \mathrm{g} / \mathrm{mL}$. Compounds 123 and 124 were active against $S$. aureus MRSA with MIC 32 and $64 \mu \mathrm{g} / \mathrm{mL}$, correspondingly. Moreover, Compound $\mathbf{1 2 3}$ showed activity against clinically important Gram-positive bacterial pathogens (S. aureus, Enterococcus faecalis, Enterococcus faecium, L. monocytogenes, Streptococcus pneumoniae). Compound $\mathbf{1 2 3}$ inhibited growth of tested pathogens at concentration in the range of $8-128 \mu \mathrm{g} / \mathrm{mL}$, and L. monocytogenes was the most sensitive clinical isolate to $\mathbf{1 2 3}$ (MIC $=8 \mu \mathrm{g} / \mathrm{mL}$ ). Additionally, Compound $\mathbf{1 2 3}$ at $2 \times$ MIC concentration, inhibited about $17 \%$ of $S$. aureus MRSA USA 300 biofilm mass [129].

The thiazolidin-4-one-thiazole hybrids (125a-125j) were tested for their antibacterial, antifungal as well as antibiofilm activities. All compounds showed antibacterial effects, but their potency was different $(\mathrm{MIC}=26.3-378.5 \mu \mathrm{M}$ ). Compound 125e with nitro group demonstrated the highest antibacterial activity with MIC in the range of 43.3-86.7 $\mu \mathrm{M}$. This compound is six-fold more potent than ampicillin and three-fold than streptomycin against all eight bacterial strains. All compounds showed very good antifungal activity against eight fungal strains at MIC of 27.7-578 $\mu \mathrm{M}$. Most active was Compound $125 \mathrm{~g}$ with MIC $=59.6-119.2 \mu \mathrm{M}$ and MFC $=119.2-238.4 \mu \mathrm{M}$. Furthermore, Compounds 125f, 125i and $125 \mathbf{j}$ reduced the biofilm-forming abilities of P. aeruginosa. The percentage of reduction by these compounds was above $50 \%$ at concentration equal to their MIC [130].

The series of thiazolidine-4-one-benzosuberone derivatives (126a-126e) was tested for their antimicrobial effects (Figure 52). Compounds 126c and 126d with pyrrolidine and piperidine moieties were the most active against bacterial (M. luteus, S. aureus MTCC 96, S. aureus MLS-16 MTTC 2940, B. subtilis, E. coli, Klebsiella planticola, P. aeruginosa), as well as fungal (C. albicans) strains. MIC were in the range of 1.9-7.8 $\mu \mathrm{g} / \mathrm{mL}$. Compound 126c showed highest activity against $B$. subtilis MTCC 121 at concentration $1.9 \mu \mathrm{g} / \mathrm{mL}$. 
Additionally, Compounds $\mathbf{1 2 6} \mathbf{c}$ and $\mathbf{1 2 6 d}$ were two-fold more active than miconazole (3.9 vs. $7.8 \mu \mathrm{g} / \mathrm{mL}$ ) against C. albicans [131].<smiles>[Z]C(=O)CCN1C(=O)CSC1C1=C(Cl)c2cc(C)c(C)cc2CCC1</smiles><smiles>[Y]c1ccc(C2=NC(N3C(=O)CSC3c3ccc([Y7])cc3)N=C(c3ccccn3)C2)cc1</smiles><smiles>[R]c1ccc(C2SCC(=O)N2c2nc(-c3ccccn3)cc(-c3cn(-c4ncccn4)cn3)n2)cc1</smiles><smiles>[R]c1ccc(/C=C2\SC(c3ccncc3)N(n3c(C)nc4ccccc4c3=O)C2=O)cc1</smiles>

127a, 130a, 131 a: $\mathrm{R}=\mathrm{H}$ 127b: $\mathrm{R}=\mathrm{OH}$

127c, 130d, 131d: $\mathrm{R}=\mathrm{Cl}$

127d: $\mathrm{R}=\mathrm{N}\left(\mathrm{CH}_{3}\right)_{2}$

128a: $\mathrm{R}=3,4,5$-triOCH

128b: $\mathrm{R}=4-\mathrm{OH}$

129a: $\mathrm{R}=3-\mathrm{OCH}_{3}$

129b: $\mathrm{R}=3-\mathrm{CH}_{3}$

129c: $\mathrm{R}=2,4-\mathrm{diCH}_{3}$

129d: $R=4-F$

129e: $\mathrm{R}=4-\mathrm{Cl}$

129f: $\mathrm{R}=4-\mathrm{NO}_{2}$

130b, 131b: $\mathrm{R}=\mathrm{CH}_{3}$

130c, 131c: $\mathrm{R}=\mathrm{OCH}$<smiles>[R]c1ccc(C2SC(C)C(=O)N2c2nnc(-c3cccc(-c4nnc(N5C(=O)C(C)SC5c5ccc([R])cn5)s4)c3)s2)nc1</smiles><smiles>[R]c1ccc(C2SC(C)C(=O)N2n2c(S)nnc2-c2cccc(-c3nnc(S)n3N3C(=O)C(C)SC3c3ccc([R])cn3)c2)nc1</smiles>

Figure 52. The structures of thiazolidin-4-one derivatives with various heterocyclic substituents in Position 3.

Compounds 127a-127d generally showed moderate antibacterial and antifungal activities, except Compound 127c. This derivative demonstrated comparable antifungal activity (inhibition zone-14 and $21 \mathrm{~mm}$ ) with amphoterecin B (inhibition zone-15 and $19 \mathrm{~mm}$ ) towards A. niger and C. albicans strains, respectively [132]. Other thiazolidine-4-one derivatives, with pyrimidine moiety $(\mathbf{1 2 8} \mathbf{a}, \mathbf{1 2 8 b})$ demonstrated good antibacterial activity with MIC in the range of $3.12-12.5 \mu \mathrm{g} / \mathrm{mL}$ against S. aureus, S. epidermidis, E. coli and Proteus mirabilis. These values were comparable to standard ciprofloxacin. The most sensitive to Compounds 128a, 128b was S. epidermidis at concentration $3.12 \mu \mathrm{g} / \mathrm{mL}$ [133].

According to Desai et al., thiazolidin-4-one quinazoline hybrids (129a-129f) exhibited good to moderate antibacterial effect. Compounds 129a and 129b, with methoxy or methyl group were most active against $S$. aureus and $E$. coli, correspondingly at concentration $12.5 \mu \mathrm{g} / \mathrm{mL}$. These values were better, than for standard chloramphenicol or ciprofloxacin $(50 \mu \mathrm{g} / \mathrm{mL})$. The Derivatives 129d-129f with para-fluoro, para-chloro and para-nitro showed comparable antifungal activity to nystatin and griseofulvin (MIC $=100-250 \mu \mathrm{g} / \mathrm{mL}$ ) against C. albicans and A. niger [134].

The screening of symmentrical bis-thiazolidin-4-ones (130a-130d and 131a-131d) for their antimicrobial activity showed good antifungal activity and moderate antibacterial effects in some cases. Therefore, Compounds 130c and 131d showed comparable zone of inhibition to ketoconazole (19 mm vs. $18 \mathrm{~mm}$ ) against $A$. flavus, while 130a, 131a and 
131d demonstrated comparable activity to ketoconazole against C. albicans (19-22 mm vs. $24 \mathrm{~mm}$ ) [135].

The Compounds 132a-132c (Figure 53) and their inclusion complex with $\beta$-cyclodextrin were tested on antibacterial activity against E. coli, S. aureus and P. vulgaris. The results showed that inclusion complex with Compounds 132a-132c had higher activity than simple small molecules (132a-132c). For example, inhibition zones of Compound 132c were in the range of 15-16 mm, while it inclusion complex showed inhibition zone at 19-21 mm [136].<smiles>[R]c1ccc(/C=C2\S/C(=N/Nc3nc4ccccc4s3)NC2=O)cc1</smiles><smiles>[Y13][13CH2]N/N=C1/SCC(=O)N1[R]</smiles><smiles>[R]c1cccc(/C=N\N=C2/NC(=O)C(Cc3cccc([R])c3)S2)c1</smiles><smiles>[R]c1ccccc1CC1S/C(=N\N=C/c2ccco2)NC1=O</smiles><smiles>[R]c1cccc(CC2S/C(=N/N=C\c3cccs3)NC2=O)c1</smiles><smiles>[R]c1ccc(-c2nn(-c3ccc([N+](=O)[O-])cc3[N+](=O)[O-])cc2/C=N\N=C2\NC(=O)CS2)cc1</smiles><smiles>Cc1cccc(/N=N/c2ccc(O)c(/C=N\N=C3/NC(=O)CS3)c2)c1</smiles><smiles>[R]OC(=O)/C=C1\S/C(=N/N=C(/[R])c2c(O)ccoc2=O)NC1=O</smiles><smiles>[R]N1C(=O)C(C)S/C1=N\N=C1/CCC(c2ccccc2)=NN1</smiles><smiles>[R]OC(=O)/C=C1/CN/C(=N/N=C(/[R])c2c(O)c3ccccc3oc2=O)S1</smiles><smiles>[R]NC(=O)CC1S/C(=N/N=C2\CCCc3ccccc32)NC1=O</smiles>

132a, 142a: $\mathrm{R}=\mathrm{H} ; 1$ 132b, 137b: $\mathrm{R}=2-\mathrm{Cl} ; 132 \mathrm{c}: \mathrm{R}=4-\mathrm{Cl} ; 133 \mathbf{a}, 142 \mathrm{~b}: \mathrm{R}=\mathrm{CH}_{3}$ 133b, 142c: $\mathrm{R}=\mathrm{C}_{2} \mathrm{H}_{5} ; 133 \mathrm{c}: \mathrm{R}=\mathrm{C}_{3} \mathrm{H}_{7} ; 133 \mathrm{~d}: \mathrm{R}=\mathrm{CH}_{2} \mathrm{CH}=\mathrm{CH}_{2} ; 133 \mathrm{e}, 142 \mathrm{~d}: \mathrm{R}=\mathrm{C}_{6} \mathrm{H}_{5}$ 134a: $\mathrm{R}=2-\mathrm{CH}_{3}, \mathrm{R}_{1}=\mathrm{H} ;$ 134b: $\mathrm{R}=4-\mathrm{Br}, \mathrm{R}_{1}=\mathrm{H} ; 134 \mathrm{c}: \mathrm{R}=4-\mathrm{OC}_{2} \mathrm{H}_{5}, \mathrm{R}_{1}=2-\mathrm{Cl}$ 134d: $\mathrm{R}=3-\mathrm{CF}_{3}, \mathrm{R}_{1}=4-\mathrm{OCH}_{3} ; 134 \mathrm{e}: \mathrm{R}=4-\mathrm{COOC}_{2} \mathrm{H}_{5}, \mathrm{R}_{1}=3,4-\mathrm{diOCH}_{3}$ 135a: $\mathrm{R}=3-\mathrm{OCH}_{3} ;$ 135b: $\mathrm{R}=3-\mathrm{CH}_{3} ; 135 \mathrm{c}: \mathrm{R}=2,4-\mathrm{diCl} ; 135 \mathrm{~d}: \mathrm{R}=2,5-\mathrm{diCl}$ 136a: $\mathrm{R}=4-\mathrm{CH}\left(\mathrm{CH}_{3}\right)_{2}$; 136b: $\mathrm{R}=4-\mathrm{Cl}$; 136c: $\mathrm{R}=3,4$-diCl; 137a: $\mathrm{R}=2,4-\mathrm{diCl} ; 137 \mathrm{c}: \mathrm{R}=4-\mathrm{F}$ 139a, 140a: $\mathrm{R}=\mathrm{CH}_{3}, \mathrm{R}_{1}=\mathrm{CH}_{3} ; 139 \mathbf{b}: \mathrm{R}=\mathrm{CH}_{3}, \mathrm{R}_{1}=\mathrm{C}_{2} \mathrm{H}_{5} ; 139 \mathrm{c}, 140 \mathrm{~b}: \mathrm{R}=\mathrm{CH}_{3}, \mathrm{R}_{1}=$ tert $-\mathrm{C}_{4} \mathrm{H}_{9}$ 139d, 140c: $R=H, R_{1}=C_{3} ; 139 e: R=H, R_{1}=C_{2} H_{5} ; 139 f: R=H, R_{1}=$ tert $-\mathrm{C}_{4} H_{9}$ 141a, 141d: $\mathrm{R}=\mathrm{C}_{6} \mathrm{H}_{5} ;$ 141b, 141e: $\mathrm{R}=\mathrm{CH}_{2} \mathrm{C}_{6} \mathrm{H}_{5} ; 141 \mathrm{c}, 141 \mathrm{f}: \mathrm{R}=\mathrm{C}_{2} \mathrm{H}_{5}$

Figure 53. The structures of 2-hydrazynilidenethiazolidin-4-ones as potential antimicrobial agents.

Compounds 133a-133e demonstrated moderate to weak antibacterial activity against E. coli, S. aureus and P. aeruginosa at concentration of 32->64 $\mathrm{gg} / \mathrm{mL}$ [137].

Chaban et al. reported generally weak antimicrobial activity of Compounds 134a-136c. Their percent of growth inhibition (GI) was less than 50\%, except Compounds 135d and 136c, that showed GI $=72.4$ and $64.4 \%$ against $S$. aureus $[138,139]$.

However, Compounds 137a-137c showed high antibacterial activity against S. aureus MRSA and S. aureus ATCC 25923. The chloro and dichloro Derivatives $\mathbf{1 3 7 b}$ and 137a were most potent against both Staphylococcus strains with MBC of $0.16 \mu \mathrm{M}$ and $1.3 \mu \mathrm{M}$, respectively. Compound 137c also was high active against MRSA $(\mathrm{MBC}=1.3 \mu \mathrm{M})[140]$. 
The diazo Derivative 138, as the only one in the series, exhibited moderate antibacterial effect against $B$. subtilis (inhibition zone $=13 \mathrm{~mm})$, S. aureus $(9 \mathrm{~mm})$ and E. coli $(10 \mathrm{~mm})$ [141].

The thiazolidine-4-one with 2H-piran moiety 139f, 140a-140c demonstrated improvement of antibacterial activity against $B$. subtilis with zone of inhibition 15-23 $\mathrm{mm}$ as well as 139d, 139e and 139f against M. luteus $(16-21 \mathrm{~mm})$. These values of inhibition zone were better than the same parameter for reference drugs erythromycin and tetracycline [142].

The Compounds 141a-141f showed comparable antibacterial and antifungal activity to reference drugs cefotaxime-sodium and nystatin. The 141a, 141b and 141e were most effective against $K$. pneumoniae with $\mathrm{MIC}=1 \mu \mathrm{mol} / \mathrm{mL}$. The 141e was also active against $C$. albicans at concentration $1 \mu \mathrm{mol} / \mathrm{mL}$ [143].

Compounds 142a and 142b exhibited better antibacterial activity than reference drugs gentamycin and amoxicillin against $S$. aureus ATCC 43300 methicillin-sensitive strain. The inhibition zone of 142a was $18 \mathrm{~mm}$ vs. 12 and $15 \mathrm{~mm}$ for gentamycin and amoxicillin, respectively. Compound $\mathbf{1 4 2 b}$ showed bactericidal effect. The Compound 142d demonstrated highest activity against $C$. albicans (fungicidal effect) and it was more active than nystatin used as standard. Derivative 142c was inactive against both above mentioned strains [144].

As reported Abo-Bakr et al. camphor-thiazolidin-4-one hybrids (143-145) (Figure 54) showed antibacterial activity against B. subtilis with inhibition \% at 65.2, 73.9 and 60.9, respectively. Moreover Compound 144 exhibited 50\% of inhibition against E. coli. Additionally, Derivatives 143 and 144 were active against C. albicans (inhibition at 51.8 and 66.7\%) and $A$. flavus (inhibition at 76 and 84\%) [145].
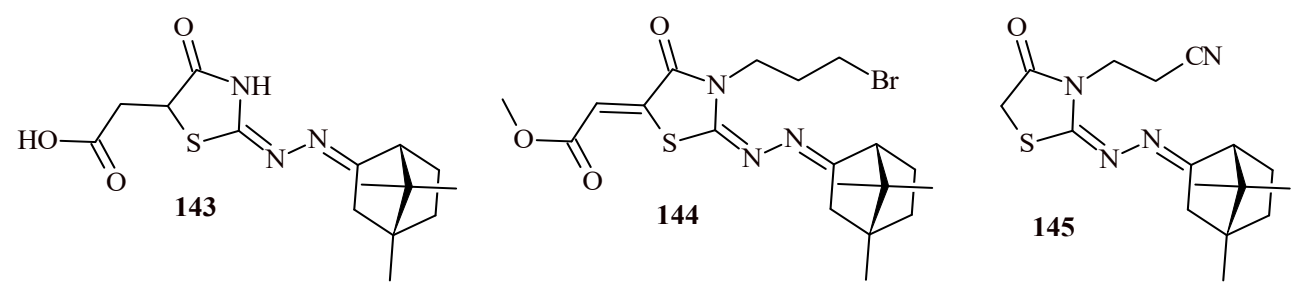

Figure 54. The structures of camphor-thiazolidine-4-one hybrids.

Konechnyi et al. also reported the moderate effects of 3-[5-(1H-indol-3-ylmethylene)4-oxo-2- thioxothiazolidin-3-yl]-propanoic acid against C. albicans (MIC $=25 \mu \mathrm{g} / \mathrm{mL}$ ) and 2-[5-(1H-indol-3-ylmethylene)-4-oxo-2-thioxothiazolidin-3-yl]-ethanesulfonic acid against E. coli and S. aureus (MIC $=25 \mu \mathrm{g} / \mathrm{mL})[146]$.

\subsection{Antitubercular Activity}

The thiazolidine-4-one derivatives show also antitubercular activity. Thus, a series of sulfamethaoxazole-thiazolidin-4-one hybrids (146a-146e) (Figure 55) showed excellent antitubercular effects against Mycobacterium bovis BCG and Mycobacterium tuberculosis H37Ra strains with $\mathrm{IC}_{90}$ values in the range of $0.058-0.22$ and $0.43-5.31 \mu \mathrm{g} / \mathrm{mL}$, respectively [147]. All most active compounds contain halogen substituent in 2-phenyl group at ortho or para positions.

A series of 2-aryl-5-methylthiazolidin-4-ones was synthesized by Ekinci et al. All compounds of this series were evaluated for antimycobacterial activity in vitro against $M$. tuberculosis H37Rv strain by microplate alamar blue assay (MABA) [148]. Only Compound 147 (Figure 55) with 2-(4-ethylphenyl) substituent showed moderate antimycobacterial effect with $\mathrm{MIC}=12.5 \mu \mathrm{g} / \mathrm{mL}$. Other compounds from series showed not significant activity $(\mathrm{MIC}=25$ or $>25 \mu \mathrm{g} / \mathrm{mL})$. 

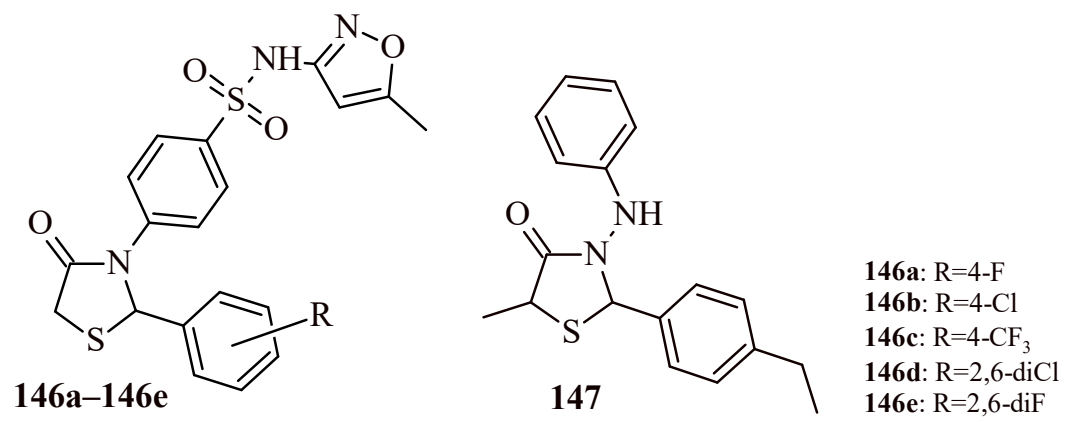

Figure 55. The 2-Arylthiazolidin-4-ones with antimycobacterial activity.

Šlachtova et al. conducted design and synthesis of a series of thiazolidine-2,4-dionehydroxamate hybrids [149]. This series was evaluated for their inhibitory activity against recombinant $M$. tuberculosis Zmp1. Nine of them inhibited enzymatic reaction at 78.1-99.8\%, that was more effective than phosphoramidon (78\% inhibition)-metalloprotease inhibitor. The weak extracellular antimycobacterial activity against $M$. tuberculosis H37Ra was shown by tested compounds. The MIC for most active Compound 148 was $61.8 \mu \mathrm{M}$. However, macrophage infection assay revealed, that most of compounds inhibited the intracellular growth of M. tuberculosis at a concentration of $10 \mu \mathrm{M}$ (Compound 149), whereas it lacks a significant extracellular activity (Figure 56).

Two series of thiazolidine-2,4-dione based derivatives (150a-150e, 151 and 152a-152g, 153a153e, 154) were obtained (Figure 56) $[150,151]$. These compounds were tested for their antimycobacterial activity against $M$. tuberculosis H37Ra strain. The isoniazid-thiazolidine-2,4-dione hybrids (150a-150e, 151) showed promising antimycobacterial activity with MIC $=1 \mu \mathrm{g} / \mathrm{mL}$. The Compounds 152a-152d, 153a, 153b and 154 from series of TZD-thiosemicarbazone derivatives exhibited good antimycobacterial activity at MIC $=2-4 \mu \mathrm{g} / \mathrm{mL}$. All these derivatives, except 154, contained phenyl or substituted phenyl group in thiosemicarbazone fragment. The unsubstituted compounds in thiosemicarbazone moiety (152e-152g and 153c-153e) showed most significant antimycobacterial effects. Their MIC values were in the range of $0.031-0.125 \mu \mathrm{g} / \mathrm{mL}$, that were better than reference drugs-isoniazid, streptomycin, ethambutol and thiacetazone. All derivatives with highest antimycobacterial effects $(\mathbf{1 5 2} \mathbf{e}-\mathbf{1 5 2} \mathrm{g}$ and $\mathbf{1 5 3 \mathrm { c }}-\mathbf{1 5 3 e})$ revealed $\mathrm{IC}_{50}$ for Vero cell line higher than rifampicin and selectivity index (SI) significantly higher than 10 it confirms their great potential in biomedical applications.

Worth noticing good antimycobacterial activity of Compounds 113a-113d (Figure 49) that inhibited mycobacterial growth of $M$. tuberculosis H37Rv strain at MIC $=1.56 \mu \mathrm{g} / \mathrm{mL}$ [120].

The very promise level of antimycobacterial activity against $M$. tuberculosis $\mathrm{H} 37 \mathrm{Rv}$ showed compounds $42 \mathrm{c}(\mathrm{MIC}=1.5 \mu \mathrm{g} / \mathrm{mL})$ and $43 \mathrm{~g}$ as well as $43 \mathrm{~h}(\mathrm{MIC}=0.8 \mu \mathrm{g} / \mathrm{mL})$ (Figure 18) [25,26]. 
<smiles>C=CCONC(=O)CN1C(=O)SC(=CCCCC)C1=O</smiles><smiles>NNC(=O)c1ccncc1</smiles>

148<smiles>[131I-]</smiles><smiles>O=C(CN1C(=O)S/C(=C\c2ccc(Cl)cc2)C1=O)NOCc1ccccc1</smiles>
149<smiles>N=Cc1cccc(OC(=O)C=C2SC(=O)NC2=O)c1</smiles><smiles>[R7]NC(=S)N/N=C/c1ccc(OC(=O)CC2SC(=O)NC2=O)c([R])c1</smiles>

152a-152g<smiles>[R7]NC(=S)N/N=C/c1ccc(OC(=O)/C=C2\SC(=O)NC2=O)c([R])c1</smiles>

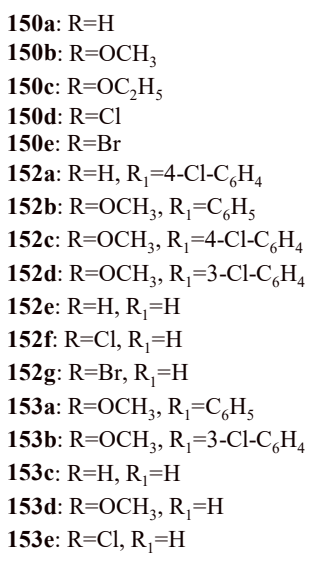

150a: $\mathrm{R}=\mathrm{H}$

150b: $\mathrm{R}=\mathrm{OCH}_{3}$

150c: $\mathrm{R}=\mathrm{OC}_{2} \mathrm{H}_{5}$

150d: $\mathrm{R}=\mathrm{Cl}$

152a: $\mathrm{R}=\mathrm{H}, \mathrm{R}_{1}=4-\mathrm{Cl}-\mathrm{C}_{6} \mathrm{H}_{4}$

152b: $\mathrm{R}=\mathrm{OCH}_{3}, \mathrm{R}_{1}=\mathrm{C}_{6} \mathrm{H}_{5}$

152c: $\mathrm{R}=\mathrm{OCH}_{3}, \mathrm{R}_{1}=4-\mathrm{Cl}_{-} \mathrm{C}_{6} \mathrm{H}_{4}$

152d: $\mathrm{R}=\mathrm{OCH}_{3}, \mathrm{R}_{1}=3-\mathrm{Cl}^{-\mathrm{C}_{6} \mathrm{H}_{4}}$

152e: $\mathrm{R}=\mathrm{H}, \mathrm{R}_{1}=\mathrm{H}$

152f: $\mathrm{R}=\mathrm{Cl}, \mathrm{R}_{1}=\mathrm{H}$

152g: $\mathrm{R}=\mathrm{Br}, \mathrm{R}_{1}=\mathrm{H}$

153a: $\mathrm{R}=\mathrm{OCH}_{3}, \mathrm{R}_{1}=\mathrm{C}_{6} \mathrm{H}_{5}$

153b: $\mathrm{R}=\mathrm{OCH}_{3}, \mathrm{R}_{1}=3-\mathrm{Cl}^{-} \mathrm{C}_{6} \mathrm{H}_{4}$

153c: $\mathrm{R}=\mathrm{H}, \mathrm{R}_{1}=\mathrm{H}$

153d: $\mathrm{R}=\mathrm{OCH}_{3}, \mathrm{R}_{1}=\mathrm{H}$

153e: $\mathrm{R}=\mathrm{Cl}, \mathrm{R}_{1}=\mathrm{H}$

Figure 56. Thiazolidine-2,4-dione derivatives with antitubercular activity.

\subsection{Antiviral Activity}

Al-Behery et al. conducted evaluation series of thiazolidin-4-one-1,3,4-thiadiazole hybrids against hepatitis $C$ virus genotype $4 a$ [152]. The results confirms that presence of 2-chloro-6-fluorophenyl and 2-chlorophenyl substituents (green color in Figure 57) have better inhibition effect of HCV NS5B GT4a than presence 3-fluoro, 4-fluoro and 4chloro substituents in benzene ring of 1,3,4-thiadiazole heterocycle. Whereas meta and para substitution in 5-benzylidene moiety of thiazolidin-4-one ring were more favorable for antivirus activity than ortho substitution. Among the series of thiazolidin-4-one-1,3,4thiadiazole hybrids, Compounds $\mathbf{1 5 5}$ and $\mathbf{1 5 6}$ revealed most potent activity with $\mathrm{IC}_{50}$ values of $0.338 \pm 0.01$ and $0.342 \pm 0.01 \mu \mathrm{M}$, respectively. 


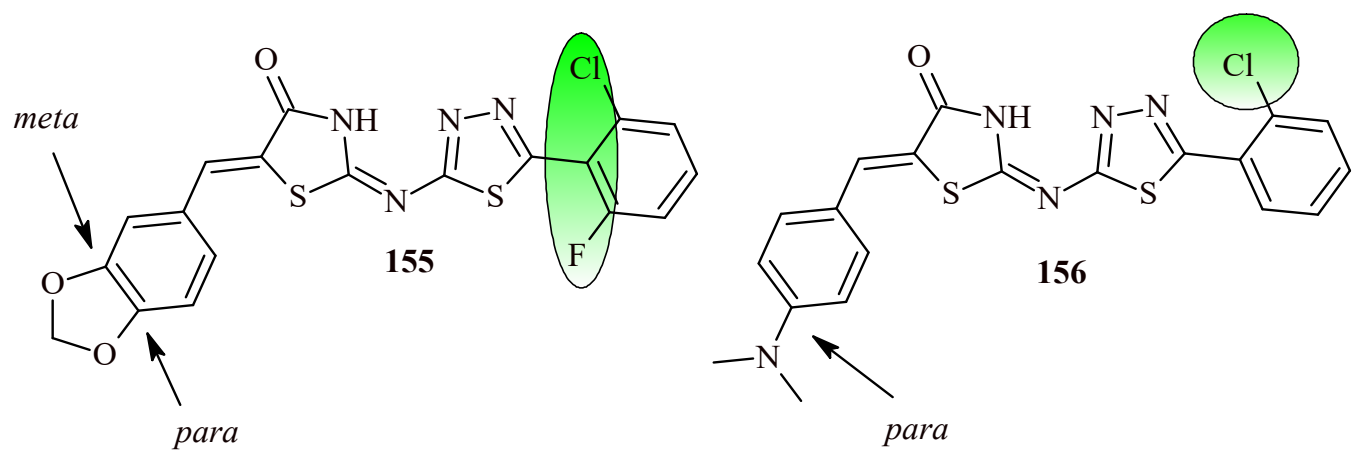

Figure 57. The structures of thiazolidin-4-one-1,3,4-thiadiazoles with activity against HCV.

Chitre et al. published the study, which aimed to designing of thiazolidin-4-one pharmacophore using QSAR studies for anti-HIV activity [153]. The 3D QSAR studies revealed, that presence of electron-withdrawing substituent such as halogenaryl in Position 2 of thiazolidin-4-one ring led to increased anti-HIV activity. The authors suggested that similarly substitution of halogenaryl moiety and sterically less bulky groups on the N-3 position of thiazolidinone ring would be preferred for increased anti-HIV activity among 2,3-diarylthiazolidin-4-ones [153].

\subsection{Cerebrovascular Protection Activity and Properties against Neurological Disorders}

Lu et al. carried out study aimed to evaluation of thiazolidin-4-one-1,3,5-triazine hybrids as protective agents towards cerebral ischemia-reperfusion injury. The derivatives showed great in vitro inhibition of NF-kB activation in RAW264.7 cells. The most effective inhibitor of NF-kB (Compound 157, $\mathrm{IC}_{50}=0.90 \pm 0.12 \mu \mathrm{M}$ ) was tested in the in vivo experiment (Figure 58). The cerebral ischemia-reperfusion injury induced by middle cerebral artery occlusion. The results demonstrated that Compound 157 showed neuroprotective effect in mice through attenuation of inflammation, oxidative stress and apoptosi. This compound (157) inhibited activation of NF-kB pathway [154].<smiles>O=C1CSC(c2ccc(F)cc2)N1c1nc(Cc2ccc([N+](=O)[O-])cc2)nc(N2CCOCC2)n1</smiles><smiles>Cc1ccc(C2SCC(=O)N2NC(=O)c2ccc(Cl)cc2Oc2ccccc2F)cc1</smiles><smiles>CSc1ccc(C2SCC(=O)N2CCCN2CCCCC2)cc1</smiles>

Figure 58. The 2-aryl thiazolidin-4-ones with cerebrovascular protection properties and used in neurological disorders.

Compound 158 as novel benzodiazepine agonist showed appropriate sedative-hypnotic activity, potent anticonvulsant activity, reduced memory impairment and no muscle relaxant influence in vivo assays. The $\mathrm{ED}_{50}$ values were $12.97 \mathrm{mg} / \mathrm{kg}$ (maximal electroshock seizures), $15.94 \mathrm{mg} / \mathrm{kg}$ (pentabarbital-induced sleeping test) and $21.07 \mathrm{~kg} / \mathrm{mg}$ (open-field test) [155].

In the study conducted by Silva et al. the antiamnestic effect of DS12 (Figure 58) in a scopolamine-induced memory deficit model in rats was investigated. Compound DS12 at both doses ( 5 and $10 \mathrm{mg} / \mathrm{kg}$ ) showed prevention memory loss induced by scopolamine. In the same doses DS12 prevented changes in acetylcholine esterase (AChE) and $\mathrm{Na}^{+} / \mathrm{K}^{+}$ ATPase activity. The DS12 also prevented the increase in AChE activity in lymphoctes after pretreatment at both doses ( 5 and $10 \mathrm{mg} / \mathrm{kg}$ ). The protection effect of DS12 on the cerebral 
cortex and hippocampus from oxidative stress caused by scopolamine confirmed at doses 5 and $10 \mathrm{mg} / \mathrm{kg}$. Therefore, DS12 appeared as a multitarget compound with antioxidative anti-inflammatory and acetylcholine esterase activities [156].

\subsection{Acetylcholine Esterase, Carbonic Anhydrase and Urease Inhibitors}

The piperonal-thiazolidin-4-one hybrids (159a-159f, 160, 161 and 4-nitro analogue of 159 (Figure 39)) showed excellent inhibitory activity against AChE at nanomolar concentration in the range of $0.84-2.81 \mathrm{nM}$. The most active was Compound $159 \mathrm{~d}$ (4-fluoro derivative) with $\mathrm{IC}_{50}=0.84 \mathrm{nM}$ (Figure 59). Whereas these derivatives inhibited human carbonic anhydrase (hCA) Isoforms I and II at submicro molar concentration ( $\left.\mathrm{IC}_{50}=91-334.3 \mathrm{nM}\right)$ [92].<smiles>[R]c1ccc(C2SCC(=O)N2Cc2ccc3c(c2)OCO3)cc1</smiles><smiles>O=C1CSC(c2cccnc2)N1Cc1ccc2c(c1)OCO2</smiles><smiles></smiles>

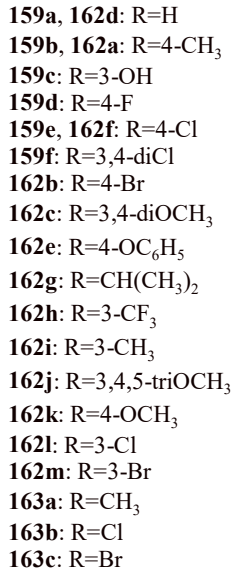
$163 \mathrm{c}: \mathrm{R}=\mathrm{Br}$<smiles>[R]CCCC(c1cn(-c2ccccc2)nc1-c1cc2ccccc2oc1=O)C1SCC(=O)N1c1ccccc1</smiles><smiles>[R]c1ccc2[nH]c(=O)cc(N/N=C3\S/C(=C\C(=O)OCC)C(=O)N3c3ccccc3)c2c1</smiles>

$162 a-162 m$

Figure 59. The structures of thiazolidine-4-one as effective AChE, hCA and urease inhibitors.

As reported Thacker et al., thiazolidine-4-one coumarin hybrids (162a-162m) showed inhibitory activity against hCA with good selectivity to hCA IX towards hCA XII. The most effective was Compound 162i that inhibited hCA IX with $\mathrm{K}_{\mathrm{i}}=61.5 \mathrm{nM}$. The $\mathrm{K}_{\mathrm{i}}$ for hCA XII was 586.6 nM [157].

The Compounds 163a-163c exhibited urease inhibitory activity with $\mathrm{IC}_{50}$ values 0.92 , 0.74 and $0.46 \mu \mathrm{M}$, respectively [158].

\section{Conclusions}

This article provides the summarizing overview of the recent information about antioxidant, anticancer, anti-inflammatory, analgesic, anticonvulsant, antidiabetic, antiparasitic, antimicrobial antitubercular and antiviral activities published in 2020 and 2021. The thiazolidin-4-one system is highly effective in the above-mentioned kinds of biological activity. Additionally, some of them showed dual-target or multitarget activity. These properties are desirable in the treatment of complex diseases such as diabetes, cardiovascular diseases, neurodegenerative syndromes or cancer. Therefore, this review may be useful for further development of the thiazolidin-4-one derivatives group as potential bioactive agents. 
Author Contributions: N.T. contributed to conceptualization, analysis, research, writing, review, and editing. D.M., A.K. and N.T. contributed to writing-original draft preparation. D.M. and A.K. contributed to literature gathering. D.M., A.K. and N.T. contributed to visualization. N.T. contributed to supervision. All authors have read and agreed to the published version of the manuscript.

Funding: This research was funded by Medical University of Lublin (DS15).

Conflicts of Interest: The authors declare no conflict of interest.

\section{Abbreviations}

15-LOX-15-lipooxygenase; 5-LOX-5-lipooxygenase; A2780—ovarian carcinoma cell line; A549-lung cancer cell line; AChE-acetylcholine esterase; ACHN—renal cancer cell line; AGS — gastric cancer cells; AKT—serine/threonine protein kinases; AR—aldose reductase; B16F10 - mouse melanoma cells; $\mathrm{Ba} / \mathrm{F}_{3}$ —leukemia cell line; $\mathrm{BALB} / \mathrm{c}$-laboratory-bred strain of the mouse; BK S-db/db-diabetic mouse model; Caco-2 - colorectal adenocarcinoma cells; CAKI-1—renal cancer cell line; $\mathrm{CC}_{50}$ - cytotoxic concentration; CCRF-CEM-human leukemic lymphoblasts; CDK1—cyclin-dependent kinase 1; CEAC-vitamin C equivalent antioxidant capacity; c-Met-tyrosine-protein kinase Met; CNS — central nervous system; COXcyclooxygenase; COX-1—cyclooxygenase-1; COX-2—cyclooxygenase-2; Dami-leukemia cell line; DLD-1-human colon cancer cells; DPPH-2,2-diphenyl-1-picrylhydrazyl; DU145prostate cancer cell line; $\mathrm{EC}_{50}$ - half maximal effective concentration; $\mathrm{ED}_{50}$-median effective dose; EGFR — epidermal growth factor receptor; hCA — human carbonic anhydrase; HCT116 human colon cancer cell line; HCV NS5B GT4a-hepatitis C virus NS5B polymerase of GT4a; HEK-293-human embryonic kidney cells; HDAC—histone deacetylase; HeLa-cervical cancer cells; HepG2-human liver cancer cell line; Het-heteryl; HGF-1—human gingival fibroblasts; HIF-1 $\alpha$-hypoxia-induced factor- $1 \alpha$; HIV—human immunodeficiency virus; HL-60leukemia cell line; HsMetAP1—human methionine aminopeptidase 1; HT-1080—fibrosarcoma cell line; HT-29-human colon cancer cell line; $\mathrm{IC}_{50}$ - half maximal inhibitory concentration; $\mathrm{IC}_{90}$ - the concentration causing $90 \%$ growth inhibition; Jurkat-leukemia cell line; K-562leukemia cell line; KBM7-SLF N233-leukemia cell line; KBM7_WT_leukemia cell line; $\mathrm{K}_{\mathrm{d}}$-dissociation constant; $\mathrm{K}_{\mathrm{i}}$-inhibition constant; $\mathrm{LD}_{50}$-median lethal dose; LDL-C—low density lipoprotein-cholesterol; LdMetAP1—Leishmania donovani methionine aminopeptidase 1; LmPTR1—Leishmania major pteridine reductase 1; MABA—microplate alamar blue assay; $\mathrm{MAO}$ - monoamine oxidase; $\mathrm{MBC}$ - minimum bactericidal concentration; MCF-7human breast cancer cell line; MDA-MB-231-human breast cancer cells; MIC - minimum inhibitory concentration; MOLT-4 - leukemia cell line; mTOR — mammalian target of rapamycin; MTT—colorimetric assay for assessing cell metabolic activity, MTT—-tetrazolium dye; NCI DTP — National Cancer Institute Development Therapeutic Program; NF-kB — nuclear factor kappa-light-chain-enhancer of activated B cells; NO-nitric oxide; p53 - tumor protein; $\mathrm{PC} 3$ prostate cancer cell line; PDB — Protein Data Bank; PDGFR $\alpha$ - platelet-derived growth factor receptor $\alpha$; PDGFR $\beta$ - platelet-derived growth factor receptor; PIM-1—serine/threonineprotein kinase; PIM-2 - serine/threonine-protein kinase; PPAR $\gamma$-peroxisome proliferator activated receptor $\gamma$; PTP1B - protein tyrosine phosphatase 1B; PTR1—pteridine reductase 1; QSAR — quantitative structure-activity relationship; RAW264.7-macrophage cells; RNAribonucleic acid; RXF393 - renal cancer cell line; SAR — structure-activity relationship; scPTZ test—-subcutaneous pentylenetetrazol seizure test; SF-295—glioblastoma cell line; SF-539CNS cancer cell line; SHSY-SY - neuroblastoma cells; SI-selectivity index; SK-MEL-5melanoma cell line; SK-MEL-28 - melanoma cell line; SR—leukemia cell line; SW-620—colon cancer cell line; TBARS — thiobarbituric acid reactive substances; TNF $\alpha$-tumor necrosis factor $\alpha$; TYRP-1—tyrosinase related protein 1; TZD—thiazolidine-2,4-dione; UO-31-renal cancer cell line; VEGF-vascular endothelial growth factor; VEGFR-2 - vascular endothelial growth factor receptor-2; WI-26 VA4 - human diploid lung fibroblasts; Zmp1-zinc-dependent metalloprotease 1. 


\section{References}

1. Kumar, A.; Chawla, A.; Jain, S.; Kumar, P.; Kumar, S. 3-Aryl-2-\{4-[4-(2,4-dioxothiazolidin-5-ylmethyl)phenoxy]-phenyl\}-acrylic acid alkyl ester: Synthesis and antihyperglycemic evaluation. Med. Chem. Res. 2011, 20, 678-686. [CrossRef]

2. Djukic, M.; Fesatidou, M.; Xenikakis, I.; Geronikaki, A.; Angelova, V.T.; Savic, V.; Pasic, M.; Krilovic, B.; Djukic, D.; Gobeljic, B.; et al. In vitro antioxidant activity of thiazolidinone derivatives of 1,3-thiazole and 1,3,4-thiadiazole. Chem. Biol. Interact. 2018, 286, 119-131. [CrossRef]

3. Trotsko, N. Antitubercular properties of thiazolidine-4-ones-A review. Eur. J. Med. Chem. 2021, 215, 113266. [CrossRef] [PubMed]

4. Trotsko, N.; Kosikowska, U.; Paneth, A.; Wujec, M.; Malm, A. Synthesis and antibacterial activity of new (2,4-dioxothiazolidin-5yl/ylidene) acetic acid derivatives with thiazolidine-2,4-dione, rhodanine and 2-thiohydantoin moieties. Saudi Pharm. J. 2018, 26, 568-577. [CrossRef]

5. Marc, G.; Ionuţ, I.; Pîrnău, A.; Vlase, L.; Vodnar, D.C.; Duma, M.; Tiperciuc, B.; Oniga, O. Microvawe assisted synthesis of 3,5-disubstituted thiazolidine-2,4-diones with antifungal activity. Design, synthesis, virtual and in vitro antifungal screening. Farmacia 2017, 65, 414-422.

6. Aneja, D.K.; Lohan, P.; Arora, S.; Sharma, C.; Aneja, K.R.; Prakash, O. Synthesis of new pyrazolyl-2,4-thiazolidinediones as antibacterial and antifungal agents. Org. Med. Chem. Lett. 2011, 1, 15. [CrossRef]

7. Trotsko, N.; Kosikowska, U.; Paneth, A.; Plech, T.; Malm, A.; Wujec, M. Synthesis and antibacterial activity of new thiazolidine2,4-dione-based chlorophenylthiosemicarbazone hybrids. Molecules 2018, 23, 1023. [CrossRef]

8. Sachin Saini, A. Synthesis and anticonvulsant studies of thiazolidinone and azetidinone derivatives from indole moiety. Drug Res. 2019, 69, 445-450.

9. Asati, V.; Mahapatra, D.K.; Bharti, S.K. Thiazolidine-2,4-diones as multi-targeted scaffold in medicinal chemistry: Potential anticancer agents. Eur. J. Med. Chem. 2014, 87, 814-833. [CrossRef] [PubMed]

10. Asati, V.; Bharti, S.K. Design, synthesis and molecular modelling studies of novel thiazolidine-2,4-dione derivatives as potential anti-cancer agents. J. Mol. Struct. 2018, 1154, 406-417. [CrossRef]

11. Trotsko, N.; Przekora, A.; Zalewska, J.; Ginalska, G.; Paneth, A.; Wujec, M. Synthesis and in vitro antiproliferative and antibacterial activity of new thiazolidine-2,4-dione derivatives. J. Enzym. Inhib. Med. Chem. 2018, 33, 17-24. [CrossRef] [PubMed]

12. Trotsko, N.; Bekier, A.; Paneth, A.; Wujec, M.; Dzitko, K. Synthesis and in vitro anti-Toxoplasma gondii activity of novel thiazolidin4-one derivatives. Molecules 2019, 24, 3029. [CrossRef]

13. Kryshchyshyn, A.; Kaminskyy, D.; Karpenko, O.; Gzella, A.; Grellier, P.; Lesyk, R. Thiazolidinone/thiazole based hybrids-New class of antitrypanosomal agents. Eur. J. Med. Chem. 2019, 174, 292-308. [CrossRef] [PubMed]

14. Barros, C.D.; Amato, A.A.; De Oliveira, T.B.; Iannini, K.B.R.; Da Silva, A.L.; Da Silva, T.G.; Leite, E.S.; Hernandes, M.Z.; De Lima, M.C.A.; Galdino, S.L.; et al. Synthesis and anti-inflammatory activity of new arylidene-thiazolidine-2,4-diones as PPAR $\gamma$ ligands. Bioorg. Med. Chem. 2010, 18, 3805-3811. [CrossRef]

15. Ghafoori, H.; Rezaei, M.; Mohammadi, A. Anti-inflammatory effects of novel thiazolidinone derivatives as bioactive heterocycles on RAW264.7 cells. Iran. J. Allergy Asthma Immunol. 2017, 16, 28-38. [PubMed]

16. Nazreen, S.; Alam, M.S.; Hamid, H.; Yar, M.S.; Dhulap, A.; Alam, P.; Pasha, M.A.Q.; Bano, S.; Alam, M.M.; Haider, S.; et al. Thiazolidine-2,4-diones derivatives as PPAR- $\gamma$ agonists: Synthesis, molecular docking, in vitro and in vivo antidiabetic activity with hepatotoxicity risk evaluation and effect on PPAR- $\gamma$ gene expression. Bioorg. Med. Chem. Lett. 2014, 24, 3034-3042. [CrossRef]

17. Devchand, P.R.; Liu, T.; Altman, R.B.; FitzGerald, G.A.; Schadt, E.E. The pioglitazone trek via human PPARgamma: From discovery to a medicine at the FDA and beyond. Front. Pharmacol. 2018, 9, 1093. [CrossRef]

18. Fang, Y.-Z.; Yang, S.; Wu, G. Free radicals, antioxidants, and nutrition. Nutrition 2002, 18, 872-879. [CrossRef]

19. Dincel, E.D.; Gürsoy, E.; Yilmaz-Ozden, T.; Ulusoy-Güzeldemirci, N. Antioxidant activity of novel imidazo[2,1- $b$ ]thiazole derivatives: Design, synthesis, biological evaluation, molecular docking study and in silico ADME prediction. Bioorg. Chem. 2020, 103, 104220. [CrossRef]

20. Kumar, H.; Deep, A.; Kumar Marwaha, R. Design, synthesis, in silico studies and biological evaluation of 5-((E)-4-((E)-(substituted aryl/alkyl)methyl)benzylidene)thiazolidine-2,4-dione derivatives. BMC Chem. 2020, 14, 25. [CrossRef]

21. Sava, A.; Buron, F.; Routier, S.; Panainte, A.; Bibire, N.; Profire, L. New nitric oxide-releasing indomethacin derivatives with 1,3-thiazolidine-4-one scaffold: Design, synthesis, in silico and in vitro studies. Biomed. Pharmacother. 2021, 139, 111679. [CrossRef]

22. Rajalakshmi, R.; Santhi, R.; Elakkiya, T. Synthesis, characterization, biological evaluation and molecular docking studies of some oxazinyl-thiazolidinone derivatives. Asian J. Chem. 2020, 32, 2125-2129. [CrossRef]

23. Shetty, C.R.; Bhat, I.K.; Kumar, A.; Kumar, M.V.; Revanasidappa, B.C.; Dkhar, G.B.F. Comventional and microwave synthesis and antioxidant evaluation of benzothiazole substituted 4-thiazolidinones. Indian Drugs 2020, 57, 17-22. [CrossRef]

24. Carraro Junior, L.R.; Alves, A.G.; Rech, T.S.T.; Campos Junior, J.C.; Siqueira, G.M.; Cunico, W.; Brüning, C.A.; Bortolatto, C.F. Three-(pyridine-2-yl)-2-(pyridin-2-ylimino)thiazolidin-4-one as a novel inhibitor of cerebral MAO-B activity with antioxidant properties and low toxicity potential. J. Biochem. Mol. Toxicol. 2021, 35, e22833. [CrossRef]

25. Verma, V.A.; Saudane, A.R. Synthesis of some novel 5-(8-substituted-11H-indolo[3,2-c]isoquinolin-5-ylthio)-1' $\mathbf{3}^{\prime}, 4^{\prime}$-oxadiazol-2amines bearing thiazolidinones and azetidinones as potential antimicrobial, antioxidant, antituberculosis, and anticancer agents. Polycycl. Aromat. Compd. 2021, 41, 871-896. [CrossRef]

26. Verma, V.A.; Saudane, A.R.; Meti, R.S.; Shamrao, R.; Katkar, V. Synthesis, biological evaluation and docking studies of some new indolyl-pyridine containing thiazolidinone and azetidinone analogs. Polycycl. Aromat. Compd. 2020, 1-15. [CrossRef] 
27. Nagai, H.; Kim, Y.H. Cancer prevention from the perspective of global cancer burden patterns. J. Thorac. Dis. $2017,9,448-451$. [CrossRef]

28. Ferlay, J.; Ervik, M.; Lam, F.; Colombet, M.; Mery, L.; Piñeros, M.; Znaor, A.; Soerjomataram, I.; Bray, F. Global Cancer Observatory: Cancer Today; International Agency for Research on Cancer: Lyon, France, 2020; Available online: https://gco.iarc.fr/today (accessed on 12 October 2021).

29. Shibuya, M. Vascular endothelial growth factor (VEGF) and its receptor (VEGFR) signaling in angiogenesis: A crucial target for anti- and pro-angiogenic therapies. Genes Cancer 2011, 2, 1097-1105. [CrossRef]

30. El-Adl, K.; El-Helby, A.-G.A.; Sakr, H.; Eissa, I.H.; El-Hddad, S.S.A.; Shoman, F.M.I.A. Design, synthesis, molecular docking and anticancer evaluations of 5-benzylidenethiazolidine-2,4-dione derivatives targeting VEGFR-2 enzyme. Bioorg. Chem. 2020, 102, 104059. [CrossRef] [PubMed]

31. El-Adl, K.; Sakr, H.; Nasser, M.; Alswah, M.; Shoman, F.M.I.A. 5-(4-Methoxybenzylidene)thiazolidine-2,4-dione-derived VEGFR-2 inhibitors: Design, synthesis, molecular docking, and anticancer evaluations. Arch. Pharm. 2020, 353, e2000079. [CrossRef]

32. Wiriyasermkul, P.; Moriyama, S.; Nagamori, S. Membrane transport proteins in melanosomes: Regulation of ions for pigmentation. Biochim. Biophys. Acta Biomembr. 2020, 1862, 183318. [CrossRef]

33. Isogawa, K.; Asano, M.; Hayazaki, M.; Koga, K.; Watanabe, M.; Suzuki, K.; Kobayashi, T.; Kawaguchi, K.; Ishizuka, A.; Kato, S.; et al. Thioxothiazolidin derivative, 4-OST, inhibits melanogenesis by enhancing the specific recruitment of tyrosinasecontaining vesicles to lysosome. J. Cell Biochem. 2021, 122, 667-678. [CrossRef]

34. Azamjah, N.; Soltan-Zadeh, Y.; Zayeri, F. Global trend of breast cancer mortality rate: A 25-year study. Asian Pac. J. Cancer Prev. 2019, 20, 2015-2020. [CrossRef] [PubMed]

35. El-Kashef, H.; Badr, G.; El-Maali, N.A.; Sayed, D.; Melnyk, P.; Lebegue, N.; El-Khalek, R.A. Synthesis of a novel series of (Z)-3,5-disubstituted thiazolidine-2,4-diones as promising anti-breast cancer agents. Bioorg. Chem. 2020, 96, 103569. [CrossRef] [PubMed]

36. Aziz, M.W.; Kamal, A.M.; Mohamed, K.O.; Elgendy, A.A. Design, synthesis and assessment of new series of quinazolinone derivatives as EGFR inhibitors along with their cytotoxic evaluation against MCF7 and A549 cancer cell lines. Bioorg. Med. Chem. Lett. 2021, 41, 127987. [CrossRef] [PubMed]

37. Abumelha, H.M.A.; Saeed, A. Synthesis of some 5-arylidene-2-(4-acetamidophenylimino)-thiazolidin-4-one derivatives and exploring their breast anticancer activity. J. Heterocycl. Chem. 2020, 57, 1816-1824. [CrossRef]

38. Kumar, V.; Rai, V.M.; Udupi, V.; Shivalingegowda, N.; Pai, V.R.; Krishnappagowda, L.N.; Pojjary, B. Synthesis, crystal structure, anticancer and molecular docking studies of quinolinone-thiazolidinone hybrid molecules. J. Iran. Chem. Soc. 2021, in press. [CrossRef]

39. Nissan, Y.M.; Mohamed, K.O.; Ahmed, W.A.; Ibrahim, D.M.; Sharaky, M.M.; Sakr, T.M.; Motaleb, M.A.; Maher, A.; Arafa, R.K. New benzenesulfonamide scaffold-based cytotoxic agents: Design, synthesis, cell viability, apoptotic activity and radioactive tracing studies. Bioorg. Chem. 2020, 96, 103577. [CrossRef]

40. Subtelna, I.; Kryshchyshyn-Dylevych, A.; Jia, R.; Lelyukh, M.; Ringler, A.; Kubicek, S.; Zagrijtschuk, O.; Kralovics, R.; Lesyk, R. 5-Arylidene-2-(4-hydroxyphenyl)aminothiazol-4(5H)-ones with selective inhibitory activity against some leukemia cell lines. Arch. Pharm. 2021, 354, e2000342. [CrossRef] [PubMed]

41. Türe, A.; Ergül, M.; Ergül, M.; Altun, A.; Küçükgüzel, I. Design, synthesis, and anticancer activity of novel 4-thiazolidinonephenylaminopyrimidine hybrids. Mol. Divers. 2020, 2, 1025-1050. [CrossRef] [PubMed]

42. Yousef, M.A.; Ali, A.M.; El-Sayed, W.M.; Qayed, W.S.; Farag, H.H.A.; Aboul-Fadl, T. Design and synthesis of novel isatin-based derivatives targeting cell cycle checkpoint pathways as potential anticancer agents. Bioorg. Chem. 2020, 105, 104366. [CrossRef]

43. Fouad, M.A.; Zaki, M.Y.; Lotfy, R.A.; Mahmoud, W.R. Insight on a new indolinone derivative as an orally bioavailable lead compound against renal cell carcinoma. Bioorg. Chem. 2021, 112, 104985. [CrossRef] [PubMed]

44. Santos-Junior, P.F.S.; Nascimento, I.J.S.; Da Silva, E.C.D.; Monteiro, K.L.C.; De Freitas, J.D.; De Lima Lins, S.; Maciel, T.M.S.; Cavalcanti, B.C.; Neto, J.B.V.; De Abreu, F.C.; et al. Synthesis of hybrids thiazole-quinoline, thiazole-indole and their analogs: In vitro anti-proliferative effects on cancer cell lines, DNA binding properties and molecular modelling. New J. Chem. 2021, 45, 13847-13859. [CrossRef]

45. Oubella, A.; El Mansouri, A.-E.; Fawzi, M.; Bimoussa, A.; Laamari, Y.; Auhmani, A.; Morjani, H.; Robert, A.; Riahi, A.; Itto, M.Y.A. Thiazolidine-linked-1,2,3-triazoles with monoterpenic skeleton as new potential anticancer agents: Design, synthesis and molecular docking studies. Bioorg. Chem. 2021, 115, 105184. [CrossRef] [PubMed]

46. Iqbal, M.A.; Husain, A.; Alam, O.; Khan, S.A.; Ahmad, A.; Haider, M.R.; Alam, M.A. Design, synthesis, and biological evaluation of imidazopyridine-linked thiazolidinone as potential anticancer agents. Arch. Pharm. 2020, 353, e2000071. [CrossRef]

47. Jori, A.; Dixit, S.R.; Pujar, G.V. Synthesis and in vitro cytotoxicity study of novel 4-substituted quinazolines encompassed with thiazolidinone and azetidinone. Asian J. Chem. 2020, 32, 2617-2623. [CrossRef]

48. Tahmasvand, R.; Bayat, P.; Vahdaniparast, S.M.; Dehghani, S.; Kooshafar, Z.; Khaleghi, S.; Almasirad, A.; Salimi, M. Design and synthesis of novel 4-thiazolidinone derivatives with promising anti-breast cancer activity: Synthesis, characterization, in vitro and in vivo results. Bioorg. Chem. 2020, 104, 104276. [CrossRef]

49. Hebishy, A.M.S.; Abdelfattah, M.S.; Elmorsy, A.; Elwany, A.H.M. Novel bis(thiazolidin-4-ones) linked to aliphatic or aromatic spacers: Synthesis, characterization, and anticancer evaluation. J. Sulfur Chem. 2021, 42, 149-166. [CrossRef] 
50. Zhou, Y.; Xu, X.; Wang, F.; He, H.; Gong, G.; Xiong, L.; Qi, B. Identification of novel quinoline analogues bearing thiazolidinones as potent kinase inhibitors for the treatment of colorectal cancer. Eur. J. Med. Chem. 2020, 204, 112643. [CrossRef] [PubMed]

51. Zhou, Y.; Xu, X.; Wang, F.; He, H.; Qi, B. Discovery of 4-((4-(4-(3-(2,6-difluorophenyl)-4-oxothiazolidin-3-yl)ureido)-2fluorophenoxy)-6-methoquinolin-7-yl)oxy)- $N, N$-diethylpiperidine-1-carboxamide as kinase inhibitor for the treatment of colorectal cancer. Bioorg. Chem. 2021, 106, 104511. [CrossRef]

52. Kobylinska, L.; Lozynskii, A.; Lesyk, R.; Stoika, R.; Vari, S.G. Biodistribution and anticancer characteristics of Les-3833, a novel 4-thiazolidinone-based lead compound. Sci. Pharm. 2020, 88, 18. [CrossRef]

53. Kobylinska, L.; Khylyuk, D.; Subtelna, I.; Kitsera, M.; Lesyk, R. In silico identification and biochemical validation of plausible molecular targets of 4-thiazolidinone derivative Les-3833 as a potential anticancer agent. Ukr. Biochem. J. 2021, 93, 7-22. [CrossRef]

54. Shawky, A.M.; Abourehab, M.A.S.; Abdalla, A.N.; Gouda, A.M. Optimization of pyrrolizine-based Schiff bases with 4thiazolidinone motif: Design, synthesis and investigation of cytotoxicity and anti-inflammatory potency. Eur. J. Med. Chem. 2020, 185, 111780. [CrossRef]

55. Buzun, K.; Kryshchyshyn-Dylevych, A.; Senkiv, J.; Roman, O.; Gzella, A.; Bielawski, K.; Bielawska, A.; Lesyk, R. Synthesis and anticancer activity evaluation of 5-[2-chloro-3-(4-nitrophenyl)-2-propenylidene]-4-thiazolidinones. Molecules 2021, $26,3057$. [CrossRef] [PubMed]

56. Kryshchyshyn, A.; Kaminskyy, D.; Roman, O.; Kralovics, R.; Karpenko, O.; Lesyk, R. Synthesis and anti-leukemic activity of pyrrolidinedione-thiazolidinone hybrids. Ukr. Biochem. J. 2020, 92, 108-119. [CrossRef]

57. Shepeta, Y.L.; Lozynskyi, A.V.; Tomkiv, Z.V.; Grellier, P.; Lesyk, R.B. Synthesis and evaluation of biological activity of rhodaninepyrazoline hybrid molecules with a 2-(2,6-dichlorophenylamino)-phenylacetamide fragment. Biopolym. Cell 2020, 36, 133-145. [CrossRef]

58. Annicotte, J.-S.; Iankova, I.; Miard, S.; Fritz, V.; Sarruf, D.; Abella, A.; Berthe, M.-L.; Noël, D.; Pillon, A.; Iborra, F.; et al. Peroxisome proliferator-activated receptor $\gamma$ regulates E-cadherin expression and inhibits growth and invasion of prostate cancer. Mol. Cell. Biol. 2006, 26, 7561-7574. [CrossRef]

59. Aouali, N.; Palissot, V.; El-Khoury, V.; Moussay, E.; Janji, B.; Pierson, S.; Brons, N.H.C.; Kellner, L.; Bosseler, M.; Van Moer, K.; et al. Peroxisome proliferator-activated receptor $\gamma$ agonists potentiate the cytotoxic effect of valproic acid in multiple myeloma Cells: PPAR $\gamma$ and valproic acid in multiple myeloma cells. Br. J. Haematol. 2009, 147, 662-671. [CrossRef] [PubMed]

60. Chang, T.-H.; Szabo, E. Enhanced growth inhibition by combination differentiation therapy with ligands of peroxisome proliferator-activated receptor- $\gamma$ and inhibitors of histone deacetylase in adenocarcinoma of the lung. Clin. Cancer Res. 2002, 8, 1206-1212.

61. Tilekar, K.; Hess, J.D.; Upadhyay, N.; Bianco, A.L.; Schweipert, M.; Laghezza, A.; Loiodice, F.; Meyer-Almes, F.-J.; Aguilera, R.J.; Lavecchia, A.; et al. Thiazolidinedione "magic bullets" simultaneously targeting PPAR $\gamma$ and HDACs: Design, synthesis, and investigations of their in vitro and in vivo antitumor effects. J. Med. Chem. 2021, 64, 6949-6971. [CrossRef]

62. Vasincu, I.-M.; Apotrosoaei, M.; Constantin, S.; Butnaru, M.; Vereştiuc, L.; Lupuşoru, C.-E.; Buron, F.; Routier, S.; Lupaşcu, D.; Tauşer, R.-G.; et al. New ibuprofen derivatives with thiazolidine-4-one scaffold with improved pharmaco-toxicological profile. BMC Pharmacol. Toxicol. 2021, 22, 10. [CrossRef]

63. Agrawal, N.; Upadhyay, P.K.; Mujwar, S.; Mishra, P. Analgesic, anti-inflammatory activity and docking study of 2-(substituted phenyl)-3-(naphthalene-1-yl)thiazolidin-4-ones. J. Indian Chem. Soc. 2020, 97, 39-46.

64. Borisova, M.S.; Ivankin, D.I.; Sokolov, D.N.; Luzina, O.A.; Rybalova, T.V.; Tolstikova, T.G.; Salakhutdinov, N.F. Synthesis, antiulcerative, and anti-inflammatory activities of new campholenic derivatives-1,3-thiazolidin-4-ones, 1,3-thiazolidine-2,4diones, and 1,3-thiazinan-4-ones. Chem. Pap. 2021, 75, 5503-5514. [CrossRef]

65. Omar, Y.M.; Abdel-Moty, S.G.; Abdu-Allah, H.H.M. Further insight into the dual COX-2 and 15-LOX anti-inflammatory activity of 1,3,4-thiadiazole-thiazolidinone hybrids: The contribution of the substituents at 5th position is size dependent. Bioorg. Chem. 2020, 97, 103657. [CrossRef] [PubMed]

66. El-Karim, S.S.A.; Mohamed, H.S.; Abdelhameed, M.F.; Amr, A.E.G.E.; Almehizia, A.A.; Nossier, E.S. Design, synthesis and molecular docking of new pyrazole-thiazolidinones as potent anti-inflammatory and analgesic agents with TNF $\alpha$ inhibitory activity. Bioorg. Chem. 2021, 111, 104827. [CrossRef] [PubMed]

67. El-Miligy, M.M.; Al-Kubeisi, A.K.; El-Zemity, S.R.; Nassra, R.A.; Abu-Serie, M.M.; Hazzaa, A.A. Discovery of small molecule acting as multitarget inhibitor of colorectal cancer by simultaneous blocking of the key COX-2, 5-LOX and PIM-1 kinase enzymes. Bioorg. Chem. 2021, 115, 105171. [CrossRef] [PubMed]

68. Shepeta, Y.; Lozynskyi, A.; Sulyma, M.; Nektegayev, I.; Grellier, P.; Lesyk, R. Synthesis and biological activity evaluation of new thiazolidinone-diclofenac hybrid molecules. Phosphorus Sulfur Silicon Relat. Elem. 2020, 195, 836-841. [CrossRef]

69. Thijs, R.D.; Surges, R.; O’Brien, T.J.; Sander, J.W. Epilepsy in adults. Lancet 2019, 393, 689-701. [CrossRef]

70. Mishchenko, M.; Shtrygol, S.; Lozynskyi, A.; Khomyak, S.; Novikov, V.; Karpenko, O.; Holota, S.; Lesyk, R. Evaluation of anticonvulsant activity of dual COX-2/5-LOX inhibitor darbufelon and its novel analogues. Sci. Pharm. 2021, 89, 22. [CrossRef]

71. Martin, L.; Rabasseda, J.; Castañer, J. Darbufelone mesilate. Drugs Future 1999, 24, 853-857. [CrossRef]

72. Bannwarth, B. Is licofelone, a dual inhibitor of cyclooxygenase and 5-lipoxygenase, a promising alternative in anti-inflammatory therapy? Fundam. Clin. Pharmacol. 2004, 18, 125-130. [CrossRef]

73. Krishnan, N.; Bonham, C.A.; Rus, I.A.; Shrestha, O.K.; Gauss, C.M.; Haque, A.; Tocilj, A.; Joshua-Tor, L.; Tonks, N.K. Harnessing insulin- and leptin-induced oxidation of PTP1B for therapeutic development. Nat. Commun. 2018, 9, 283. [CrossRef] 
74. Chen, K.; Yao, X.; Tang, T.; Chen, L.-M.; Xiao, C.; Wang, J.-Y.; Chen, H.-F.; Jiang, Z.-X.; Liu, Y.; Zheng, X. Thiazole-based and thiazolidine-based protein tyrosine phosphatise 1B inhibitors as potential anti-diabetic agents. Med. Chem. Res. 2021, 30, 519-534. [CrossRef]

75. Boucher, J.; Kleinridders, A.; Kahn, C.R. Insulin receptor signaling in normal and insulin-resistant states. Cold Spring Harb. Perspect. Biol. 2014, 6, a009191.

76. Elchebly, M.; Payette, P.; Michaliszyn, E.; Cromlish, W.; Collins, S.; Loy, A.L.; Normandin, D.; Cheng, A.; Himms-Hagen, J.; Chan, C.C.; et al. Increased insulin sensitivity and obesity resistance in mice lacking the protein tyrosine phosphatase-1B gene. Science 1999, 283, 1544-1548. [CrossRef] [PubMed]

77. Klaman, L.D.; Boss, O.; Peroni, O.D.; Kim, J.K.; Martino, J.L.; Zabolotny, J.M.; Moghal, N.; Lubkin, M.; Kim, Y.B.; Sharpe, A.H.; et al. Increased energy expenditure, decreased adiposity, and tissue-specific insulin sensitivity in protein-tyrosine phosphatase 1B-deficient mice. Mol. Cell. Biol. 2000, 20, 5479-5489. [CrossRef] [PubMed]

78. Kennedy, B.P.; Ramachandran, C. Protein tyrosine phosphatase-1B in diabetes. Biochem. Pharmacol. 2000, 60, 877-883. [CrossRef]

79. Ramachandran, C.; Kennedy, B.P. Protein tyrosine phosphatase 1B: A novel target for type 2 diabetes and obesity. Curr. Top. Med. Chem. 2003, 3, 749-757. [CrossRef] [PubMed]

80. Panzhinskiy, E.; Ren, J.; Nair, S. Protein tyrosine phosphatase 1B and insulin resistance: Role of endoplasmic reticulum stress/reactive oxygen species/nuclear factor kappa B axis. PLoS ONE 2013, 8, e77228. [CrossRef]

81. Abdelsalam, S.S.; Korashy, H.M.; Zeidan, A.; Agouni, A. The role of protein tyrosine phosphatase (PTP)-1B in cardiovascular disease and its interplay with insulin resistance. Biomolecules 2019, 9, 286. [CrossRef]

82. Patel, A.D.; Pasha, T.Y.; Lunagariya, P.; Shah, U.; Bhambharoliya, T.; Tripathi, R.K.P. A library of thiazolidin-4-one derivatives as protein tyrosine phosphatase 1B (PTP1B) inhibitors: An attempt to discover novel antidiabetic agents. ChemMedChem 2020, 15, 1229-1242. [CrossRef]

83. Jiang, B.; Luo, J.; Guo, S.; Wang, L. Discovery of 5-(3-bromo-2-(2,3-dibromo-4,5-dimethoxybenzyl)-4,5- dimethoxybenzylidene)thiazolidine2,4-dione as a novel potent protein tyrosine phosphatase 1B inhibitor with antidiabetic properties. Bioorg. Chem. 2021, 108, 104648. [CrossRef]

84. Joshi, S.R.; Standl, E.; Tong, N.; Shah, P.; Kalra, S.; Rathod, R. Therapeutic potential of $\alpha$-glucosidase inhibitors in type 2 diabetes mellitus: An evidence-based review. Expert Opin. Pharmacother. 2015, 16, 1959-1981. [CrossRef]

85. Rafique, R.; Khan, K.M.; Arshia, K.; Chigurupati, S.; Wadood, A.; Rehman, A.U.; Karunanidhi, A.; Hameed, S.; Taha, M.; Al-Rashida, M. Synthesis of new indazole based dual inhibitors of $\alpha$-glucosidase and $\alpha$-amylase enzymes, their in vitro, in silico and kinetics studies. Bioorg. Chem. 2020, 94, 103195. [CrossRef]

86. Leroux-Stewart, J.; Rabasa-Lhoret, R.; Chiasson, J.-L. Diabetic mastopathy: Case report and summary of literature. Can. J. Diabetes 2014, 38, 305-306. [CrossRef]

87. Fettach, S.; Thari, F.Z.; Hafidi, Z.; Tachallait, H.; Karrouchi, K.; El Achouri, M.; Cherrah, Y.; Sefrioui, H.; Bougrin, K.; El Abbes Faouzi, M. Synthesis, $\alpha$-glucosidase and $\alpha$-amylase inhibitory activities, acute toxicity and molecular docking studies of thiazolidine-2,4-diones derivatives. J. Biomol. Struct. Dyn. 2021, in press. [CrossRef]

88. Toumi, A.; Boudriga, S.; Hamden, K.; Sobeh, M.; Cheurfa, M.; Askri, M.; Knorr, M.; Strohmann, C.; Brieger, L. Synthesis, antidiabetic activity and molecular docking study of rhodanine-substituted spirooxindole pyrrolidine derivatives as novel $\alpha$-amylase inhibitors. Bioorg. Chem. 2021, 106, 104507. [CrossRef] [PubMed]

89. Toumi, A.; Boudriga, S.; Hamden, K.; Daoud, I.; Askri, M.; Solder, A.; Lohier, J.-F.; Strohmann, C.; Brieger, L.; Knorr, M. Diversityoriented synthesis of spiropyrrolo[1,2-a]isoquinoline derivatives via diastereoselective and regiodivergent three-component 1,3-dipolar cycloaddition reactions: In vitro and in vivo evaluation of the antidiabetic activity of rhodanine analogues. J. Org. Chem. 2021, 86, 13420-13445. [CrossRef] [PubMed]

90. Maccari, R.; Del Corso, A.; Paoli, P.; Adornato, I.; Lori, G.; Balestri, F.; Cappiello, M.; Naß, A.; Wolber, G.; Ottanà, R. An investigation on 4-thiazolidinone derivatives as dual inhibitors of aldose reductase and protein tyrosine phosphatase $1 \mathrm{~B}$, in the search for potential agents for the treatment of type 2 diabetes mellitus and its complications. Bioorg. Med. Chem. Lett. 2018, 28, 3712-3720. [CrossRef]

91. Szabo, K.; Maccari, R.; Ottana, R.; Gyemant, G. Extending the investigation of 4-thiazolidinone derivatives as potential multitarget ligands of enzymes involved in diabetes mellitus and its long-term complications: A study with pancreatic $\alpha$-amylase. Carbohydr. Res. 2021, 499, 108220. [CrossRef] [PubMed]

92. Bilgicli, H.G.; Taslimi, P.; Akyuz, B.; Tuzun, B.; Gulcin, I. Synthesis, characterization, biological evaluation, and molecular docking studies of some piperonyl-based 4-thiazolidinone derivatives. Arch. Pharm. Chem. Life Sci. 2020, 353, 1900304. [CrossRef] [PubMed]

93. Burza, S.; Croft, S.L.; Boelaert, M. Leishmaniasis. Lancet 2018, 392, 951-970. [CrossRef]

94. Thakur, L.; Singh, K.K.; Shanker, V.; Negi, A.; Jain, A.; Matlashewski, G.; Jain, M. Atypical leishmaniasis: A global perspective with emphasis on the Indian subcontinent. PLoS Negl. Trop. Dis. 2018, 12, e0006659. [CrossRef]

95. Sundar, S.; Chakravarty, J. Antimony toxicity. Int. J. Environ. Res. Public Health 2010, 7, 4267-4277. [CrossRef] [PubMed]

96. Mohapatra, S. Drug resistance in leishmaniasis: Newer developments. Trop. Parasitol. 2014, 4, 4-9. [CrossRef] [PubMed]

97. Bhat, S.Y.; Bhandari, S.; Thacker, P.S.; Arifuddin, M.; Qureshi, I.A. Development of quinoline-based hybrid as inhibitor of methionine aminopeptidase 1 from Leishmania donovani. Chem. Biol. Drug Des. 2021, 97, 315-324. [CrossRef] 
98. Bhat, S.Y.; Dey, A.; Qureshi, I.A. Structural and functional highlights of methionine aminopeptidase 2 from Leishmania donovani. Int. J. Biol. Macromol. 2018, 115, 940-954. [CrossRef]

99. D'souza, V.M.; Holz, R.C. The methionyl aminopeptidase from Escherichia coli can function as an iron (II) enzyme? Biochemistry 1999, 38, 11079-11085. [PubMed]

100. Wang, J.; Sheppard, G.S.; Lou, P.; Kawai, M.; Park, C.; Egan, D.A.; Schneider, A.; Bouska, J.; Lesniewski, R.; Henkin, J. Physiologically relevant metal cofactor for methionine aminopeptidase-2 is manganese. Biochemistry 2003, 42, 5035-5042. [CrossRef]

101. Schadich, E.; Kryshchyshyn-Dylevych, A.; Holota, S.; Polishchuk, P.; Džubak, P.; Gurska, S.; Hajduch, M.; Lesyk, R. Assessing different thiazolidine and thiazole based compounds as antileishmanial scaffolds. Bioorg. Med. Chem. Lett. 2020, 30, 127616. [CrossRef] [PubMed]

102. Nare, B.; Hard, L.W.; Beverley, S.M. The roles of pteridine reductase 1 and synthase in pteridine metabolism in the protozoan parasite Leishmania major. J. Biol. Chem. 1997, 272, 13883-13891. [CrossRef] [PubMed]

103. Cavazzuti, A.; Paglietti, G.; Hunter, W.N.; Gamarro, F.; Piras, S.; Loriga, M.; Allecca, S.; Corona, P.; McLuskey, K.; Tulloch, L.; et al. Discovery of potent pteridine reductase inhibitors to guide antiparasite drug development. Proc. Natl. Acad. Sci. USA 2008, 105, 1448-1453. [CrossRef]

104. Leite, F.H.A.; Santiago, P.B.G.S.; Froes, T.Q.; Da Silva Filho, J.; Da Silva, S.G.; Ximenes, R.M.; De Faria, A.R.; Brondani, D.J.; De Albuquerque, J.F.C.; Castilho, M.S. Structure-guided discovery of thiazolidine-2,4-dione derivatives as a novel class of Leishmania major pteridine reductase 1 inhibitors. Eur. J. Med. Chem. 2016, 123, 639-648. [CrossRef] [PubMed]

105. Vickers, T.J.; Beverley, S.M. Folate metabolic pathways in Leishmania. Essays Biochem. 2011, 51, 63-80.

106. Neri, F.S.M.; Costa Júnior, D.B.; Froes, T.Q.; Da Silva, P.B.G.; Soares do Egito, M.; Moreira, P.O.L.; De Pilla Varotti, F.; Castilho, M.S.; Teixeira-Neto, R.G.; De Albuquerque, J.F.C.; et al. Antileishmanial activity evaluation of thiazolidine-2,4-dione against Leishmania infantum and Leishmania braziliensis. Parasitol. Res. 2020, 119, 2263-2274. [CrossRef]

107. Haroon, M.; De Barros Dias, M.C.H.; Da Silva Santos, A.C.; Pereira, V.R.A.; Barros Freitas, L.A.; Balbinot, R.B.; Kaplum, V.; Nakamura, C.V.; Alves, L.C.; Brayner, F.A.; et al. The design, synthesis, and in vitro trypanocidal and leishmanicidal activities of 1,3-thiazole and 4-thiazolidinone ester derivatives. RSC Adv. 2021, 11, 2487-2500. [CrossRef]

108. Kryshchyshyn-Dylevych, A.P.; Zelisko, N.I.; Grellier, P.; Lesyk, R.B. Preliminary evaluation of thiazolidinone- and pyrazolinerelated heterocyclic derivatives as potential antimalarial agents. Biopolym. Cell 2020, 36, 48-60. [CrossRef]

109. Molina, D.A.; Ramos, G.A.; Zamora-Velez, A.; Gallego-Lopez, G.M.; Rocha-Roa, C.; Gomez-Martin, J.E.; Cortes, E. In vitro evaluation of new 4-thiazolidinones on invasion and growth of Toxoplasma gondii. Int. J. Parasitol. Drugs Drug Resist. 2021, 16, 129-139. [CrossRef]

110. Kryshchyshyn-Dylevych, A.P. 5-Ene-rhodanine-3-carboxylic acids as potential antimicrobial and antiparasitic agents. Biopolym. Cell 2020, 36, 229-241. [CrossRef]

111. Piddock, L.J.V. The crisis of no new antibiotics—What is the way forward? Lancet Infect. Dis. 2012, 12, 249-253. [CrossRef]

112. Cheng, G.; Dai, M.; Ahmed, S.; Hao, H.; Wang, X.; Yuan, Z. Antimicrobial drugs in fighting against antimicrobial resistance. Front. Microbiol. 2016, 7, 470. [CrossRef]

113. Chaban, T.; Matiichuk, Y.; Chulovska, Z.; Tymoshuk, O.; Chaban, I.; Matiychuk, V. Synthesis and biological evaluation of new 4-oxo-thiazolidin-2-ylidene derivatives as antimicrobial agents. Arch. Pharm. 2021, 354, e2100037. [CrossRef]

114. Horishny, V.; Chaban, T.; Matiychuk, V. Synthesis of new 2-(4-oxothiazolidin-2-ylidene)-acetamides as potential antimicrobial agents. FARAD J. Pharm. Sci. 2020, 45, 211-218.

115. Mangasuli, S.N. Synthesis of novel coumarin-thiazolidine-2,4-dione derivatives: An approach to computational studies and biological evaluation. Res. Chem. 2021, 3, 100105.

116. Kulkami, P.S.; Karale, S.N.; Khandebharad, A.U.; Agrawal, B.R.; Sarda, S.R. Design, synthesis, and biological evaluation of newer arylidene incorporated 4-thiazolidinones derivatives as potential antimicrobial agents. Polycycl. Aromat. Compd. 2020, in press. [CrossRef]

117. Haroun, M.; Tratrat, C.; Petrou, A.; Geroniaki, A.; Ivanov, M.; Ciric, A.; Sokovic, M. 2-Aryl-3-(6-trifluoromethoxy)benzo[d]thiazolebased thiazolidinone hybrids as potential anti-infective agents: Synthesis, biological evaluation and molecular docking studies. Bioorg. Med. Chem. Lett. 2021, 32, 127718. [CrossRef] [PubMed]

118. Haroun, M.; Tratrat, C.; Petrou, A.; Geronikaki, A.; Ivanov, M.; Ciric, A.; Sokovic, M.; Nagaraja, S.; Venugopala, N.K.; Nair, A.B.; et al. Exploration of the antimicrobial effects of benzothiazolylthiazolidin-4-one and in silico mechanistic investigation. Molecules 2021, 26, 4061. [CrossRef] [PubMed]

119. Cheddie, A.; Shintre, S.A.; Bantho, A.; Mocktar, C.; Koorbanally, N.A. Synthesis and antibacterial activity of series of 2trifluoromethylbenzimidazole-thiazolidinone derivatives. J. Heterocycl. Chem. 2020, 57, 299-307. [CrossRef]

120. Zhang, H.; Zhang, J.; Qu, W.; Xie, S.; Huang, L.; Chen, D.; Tao, Y.; Liu, Z.; Pan, Y.; Yuan, Z. Design, synthesis, and biological evaluation of novel thiazolidinone-containing quinoxaline-1,4-di- $N$-oxides as antimycobacterial and antifungal agents. Front. Chem. 2020, 8, 598. [CrossRef] [PubMed]

121. Hrichi, H.; Elkanzi, N.A.A.; Bakr, R.B. Novel $\beta$-lactams and thiazolidinone derivatives from 1,4-dihydroquinoxaline Schiff's base: Synthesis, antimicrobial activity and molecular docking studies. Chem. J. Mold. 2020, 15, 86-94. [CrossRef]

122. Al-Amiery, A.; Shaker, L.M.; Gaaz, T.S. Synthesis and structure elucidationfor N-(2-phenyl-4-thiazolidinone-3-yl)-2-(coumarin-4yloxy)acetamide and assessment antibacterial characteristics. Biointerface Res. Appl. Chem. 2021, 11, 11338-11346. 
123. Ismael, S.S.; Mahdi, M.F.; Razik, B.M.A. Design, synthesis and antibacterial study of new agents having 4-thiazolidinone pharmacophore. Egypt. J. Chem. 2020, 63, 2591-2603. [CrossRef]

124. Shirke, M.; Gangthade, M.; Chaskar, P.; Somani, R. Synthesis, characterization and pharmacological evaluation of bifenyl based 4-thiazolidinones. Indian J. Pharm. Edu. Res. 2021, 55, 363-373. [CrossRef]

125. Güzel-Akdemir, Ö.; Trawally, M.; Özbek-Babuç, M.; Özbek-Çelik, B. Synthesis and antibacterial activity of new hybrid derivatives of 5-sulfamoyl-1H-indole and 4-thiazolidinone groups. Mon. Chem. 2020, 151, 1443-1452. [CrossRef]

126. Srivastava, K.; Singh, R.B.; Srivastava, J.; Gupta, D. Designing, synthesis and characterization of novel substituted pyrazolazetidin-2-one/thiazolidine-4-one derivatives for their antimicrobial activity. Pharma Chem. 2021, 13, 11-17.

127. Thach, T.; Tuong-Vile, T.; Nguyen, H.T.-A.; Dang, C.-H.; Dang, V.-S.; Nguyen, T.-D. Synthesis of sulfonamides bearing 1,3,5triaarylpyrazoline and 4-thiazolidinone moieties as novel antimicrobial agents. J. Serb. Chem. Soc. 2020, 85, 155-162. [CrossRef]

128. Hammad, S.G.; El-Gazzar, M.G.; Abdel-Halim, M.; Elrazaz, E.Z.; El-Hossary, E.M.; Abouzid, K.A.M. Antimicrobial and cytotoxicity evaluation of new 3-allyl-2-iminothiazolidin-4-ones. Egypt. J. Chem. 2021, 64, 4919-4930.

129. Hammad, S.G.; El-Gazzar, M.G.; Abutaleb, N.S.; Li, D.; Ramming, I.; Shekhar, A.; Abdel-Halim, M.; Elrazaz, E.Z.; Seleem, M.N.; Bilitewski, U.; et al. Synthesis and antimicrobial evaluation of new halogenated1,3-thiazolidin-4-ones. Bioorg. Chem. 2020, 95, 103517. [CrossRef]

130. Haroun, M.; Tratrat, C.; Kolokotroni, A.; Petrou, A.; Geronikaki, A.; Ivanov, M.; Kostic, M.; Sokovic, M.; Carazo, A.; Mladenka, P.; et al. 5-Benzyliden-2-(5-methylthiazol-2-ylimino)thiazolidine-4-ones as antimicrobial agents. Design, synthesis, biological evaluation and molecular docking studies. Antibiotics 2021, 10, 309. [CrossRef]

131. Jilla, L.; Kolluri, P.K.; Bujji, S.; Naikal, S.J.P. Synthesis and antimicrobial agents of thiazolidinone derivatives from benzocycloheptenone. J. Heterocycl. Chem. 2020, 57, 4078-4087. [CrossRef]

132. Bakr, R.B.; Elkanzi, N.A.A. Preparation of some novel thiazolidinones, imidazolinones, and azetidinone bearing pyridine and pyrimidine moieties with antimicrobial activity. J. Heterocycl. Chem. 2020, 57, 2977-2989. [CrossRef]

133. Arshad, M.; Khan, M.S.; Nami, S.A.A.; Ahmad, S.I.; Kashif, M.; Anjum, A. Synthesis, characterization, biological, and molecular docking assessment of bioactive 1,3-thiazolidin-4-ones fused with 1-(pyrimidin-2-yl)-1H-imidazol-4-yl) moieties. J. Iran. Chem. Soc. 2021, 18, 1713-1727. [CrossRef]

134. Desai, N.C.; Jadeja, K.A.; Jadeja, D.J.; Khedkar, V.M.; Jha, P.C. Design, synthesis, antimicrobial evaluation, and molecular docking study of some 4-thiazolidinone derivatives containing pyridine and quinazoline moiety. Synth. Commun. 2021, 51, 952-963.

135. Ayyash, A.N.; Hammady, A.O. Synthesis and bioactivity screening of new 13,-thiazolidin-4-one compounds bearing (thiadiazoles/triazoles) moieties. J. Phys. Conf. Ser. 2020, 1660, 012025. [CrossRef]

136. Dash, S. Inclusion complexes of some substituted 4-thiazoldinones with activating and deactivating group. Asian J. Chem. 2020, 32, 133-136. [CrossRef]

137. Dincel, E.D.; Ulusoy-Güzeldemirci, N.; Şatana, D.; Küçükbasmaci, Ö. Design, synthesis, characterization and antimicrobial evaluation of some novel hydrazinecarbothioamide, 4-thiazolidinone and 1,2,4-triazole-3-thione derivatives. J. Heterocycl. Chem. 2021, 58, 195-205. [CrossRef]

138. Drapak, I.V.; Logoyda, L.S.; Shtoyko, N.Y.; Sulyma, M.I.; Chaban, T.I.; Matiychuk, V.S. Synthesis and antimicrobial activity of 5-R-benzyl-2-(arylidenehydrazono)thiazolidine-4-ones. Biopolym. Cell 2020, 36, 457-465. [CrossRef]

139. Chaban, T.; Horishny, V.; Arshad, M.; Chulovska, Z.; Kostyshyn, L.; Drapak, I.; Matiychuk, V. Synthesis, molecular docking and antimicrobial activities of 5-(4-substituted-benzyl)-2-(furan/thiophen-2-ylmethylene hydrazono) thiazolidin-4-ones. Biointerface Res. Appl. Chem. 2021, 11, 12434-12446.

140. Ebenezer, O.; Singh-Pillay, A.; Koorbanally, N.A.; Singh, P. Antibacterial evaluation and molecular docking studies of pyrazolethiosemicarbazones and their pyrazole-thiazolidinone conjugates. Mol. Divers. 2021, 25, 191-204. [CrossRef]

141. Salem, M.A.; Abbas, S.Y.; El-Sharief, M.A.M.S.; Alzahrani, A.Y.; Helal, M.H.; Thabet, H.K. Synthesis and antimicrobial activity of 4-methylthiazole and 4-thiazolidinone derivatives derived from 5-(aryldiazo)salicylaldehyde thiosemicarbazones. Synth. Commun. 2021, in press. [CrossRef]

142. Mirakmahaleh, M.S.; Rad-Moghadam, K.; Kefayati, H.; Falakro, S. Expedient synthesis of novel antibacterial hydrazono-4thiazolidinones under catalysisof a natural-based binary ionic liquid. Mol. Divers. 2021, 25, 109-119. [CrossRef]

143. Abu-Hashem, A.A. Synthesis and antimicrobial activity of new 1,2,4-triazole, 1,3,4-oxadiazole, 1,3,4-thiadiazole, thiopyrane, thiazolidinone, andazepine derivatives. J. Heterocycl. Chem. 2021, 58, 74-92. [CrossRef]

144. Salhi, L.; Achouche-Bouzroura, S.; Nechak, R.; Nedjar-Kolli, B.; Rabia, C.; Merazig, H.; Poulain-Martini, S.; Dunach, T.E. Synthesis of functionalized dihydroimidazo[1,2-a]pyridines and 4-thiazolidinone derivatives from maleimide, as new class of antimicrobial agants. Synth. Commun. 2020, 50, 412-422. [CrossRef]

145. Abo-Bakr, A.M.; Hassan, E.A.; Mahdy, A.H.S.; Zayed, S.E. Synthetic and biological studies on some new camphor thiazolidinones. J. Iran. Chem. Soc. 2021, 18, 2757-2769. [CrossRef]

146. Konechnyi, Y.T.; Lozynskyi, A.V.; Horishny, V.Y.; Konechna, R.T.; Vynnytska, R.B.; Korniychuk, O.P.; Lesyk, R.B. Synthesis of indoline-thiazolidinone hybrids with antibacterial and antifungal activities. Biopolym. Cell 2020, 36, 381-391. [CrossRef]

147. Bhat, M.A.; Al-Omar, M.A.; Naglah, A.M.; Khan, A.A. Synthesis of novel sulfamethaoxazole 4-thiazolidinone hybrids and their biological evaluation. Molecules 2020, 25, 3570. [CrossRef]

148. Ekinci, A.S.; Moncol, J.; Krishna, V.S.; Sriram, D.; Özadali-Sari, K. 5-methyl-4-thiazolidinones: Synthesis and evaluation as antitubercular agents. J. Res. Pharm. 2020, 24, 30-37. [CrossRef] 
149. Šlachtová, V.; Šebela, M.; Torfs, E.; Oorts, L.; Cappoen, D.; Berka, K.; Bazgier, V.; Brulíková, L. Novel thiazolidinedionehydroxamates as inhibitors of Mycobacterium tuberculosis virulence factor Zmp1. Eur. J. Med. Chem. 2020, 185, 111812. [CrossRef] [PubMed]

150. Trotsko, N.; Golus, J.; Kazimierczak, P.; Paneth, A.; Przekora, A.; Ginalska, G.; Wujec, M. Synthesis and antimycobacterial activity of thiazolidine-2,4-dione based derivatives with halogenbenzohydrazones and pyridinecarbohydrazones substituents. Eur. J. Med. Chem. 2020, 189, 112045. [CrossRef]

151. Trotsko, N.; Golus, J.; Kazimierczak, P.; Paneth, A.; Przekora, A.; Ginalska, G.; Wujec, M. Design, synthesis and antimycobacterial activity of thiazolidine-2,4-dionebased thiosemicarbazone derivatives. Bioorg. Chem. 2020, 97, 103676. [CrossRef]

152. Al-Behery, A.S.; Elberembally, K.M.; Eldawy, M.A. Synthesis, docking, and biological evaluation of thiazolidinone derivatives against hepatitis C virus genotype 4a. Med. Chem. Res. 2021, 30, 1151-1165. [CrossRef]

153. Chitre, T.S.; Patil, S.M.; Sujalegaonkar, A.G.; Asgaonkar, K.D. Designing of thiazolidine-4-one pharmacophore using QSAR studies for anti-HIV activity. Indian J. Pharm. Educ. Res. 2021, 55, 581-589. [CrossRef]

154. Lu, M.; Qi, Y.; Han, Y.; Yi, Q.; Xu, L.; Sun, W.; Ni, G.; Ni, X.; Xu, C. Designing and development of novel thiazolidine-4-one-1,3,5triazine derivatives as neuro-protective agent against cerebral ischemia-reperfusion injury in mice via attenuation of NF-kB. Chem. Biol. Drug Des. 2020, 96, 1315-1327. [CrossRef] [PubMed]

155. Almasirad, A.; Ghadimi, M.; Mirahmadi, S.; Kodakan, P.A.; Jahani, R.; Nazari, M.; Rezaee, E.; Azizian, H.; Rabizadeh, P.; Tabatabai, S.A.; et al. Design, synthesis, and preliminary pharmacological evaluation of novel thiazolidinone derivatives as potential benzodiazepine agonists. Mol. Divers. 2021, in press. [CrossRef]

156. Da Silva, D.S.; Soares, M.S.P.; Teixeira, F.C.; De Mello, J.E.; De Souza, A.A.; Luduvico, K.P.; De Andrade, C.M.; Spanevello, R.M.; Cunico, W. Multitarget effect of 2-(4-(methylthio)phenyl)-3-(3-(piperidin-1-yl)propyl)thiazolidine-4-one in a scopolamine-induced amnesic rat model. Neurochem. Res. 2021, 46, 1554-1566. [CrossRef] [PubMed]

157. Thacker, P.S.; Goud, N.S.; Argulwar, O.S.; Soman, J.; Angeli, A.; Alvala, M.; Arifuddin, M.; Supuran, C.T. Synthesis and biological evaluation of some coumarin hybrids as selective carbonic anhydrase IX and XII inhibitors. Bioorg. Chem. 2020, 104, 104272. [CrossRef]

158. Elbastawesy, M.A.; Aly, A.A.; El-Shaer, Y.A.; Brown, A.B.; Abuo-Rahma, G.E.D.A.; Ramadan, M. New 4-thiazolidinone/quinoline2-ones scaffold: Design, synthesis, docking studies and biological evaluation as potential urease inhibitors. J. Mol. Struct. 2021, 1244, 130845. [CrossRef] 